\title{
41. TECTONISM AND VOLCANISM AT THE SOUTHEAST GREENLAND RIFTED MARGIN: A RECORD OF PLUME IMPACT AND LATER CONTINENTAL RUPTURE ${ }^{1}$
}

\author{
H.C. Larsen² and A.D. Saunders ${ }^{3}$
}

\begin{abstract}
During Ocean Drilling Program Leg 152, Sites 914 through 919 were drilled on the southeast Greenland Margin along a transect from the middle shelf into the adjacent deep-water Irminger Basin $500 \mathrm{~km}$ south of the Iceland hot-spot track (IcelandGreenland Ridge). Sites 915 through 918 penetrated the entire cover of postrift sediments, and three of these four sites sampled the volcanic basement of the seaward-dipping reflector sequences (SDRS). The landward featheredge of the SDRS was drilled at the most landward site, Site 917, where a 779.5-m-thick, south to southeastward dipping volcanic section was found to overlie steeply dipping, marine pre-rift sediments of unknown, possibly Cretaceous, age. The more seaward Site 915 (later deepened by Site 990) recovered two lava flows that are stratigraphically located above Site 917 and located within the oldest part of the main SDRS wedge. The central part of the SDRS wedge was penetrated at Site 918 in the Irminger Basin where a 120-mthick lava section was recovered below $1189 \mathrm{~m}$ of postrift sediments. A few sills and dikes were sampled. All other igneous units recovered were subaerially erupted and deposited lavas, some of which may have flowed over wet ground or into shallow water. Lavas at Site 917 display compositions ranging from picrite over olivine basalt to basalt, dacite, and acid tuffs. The younger lavas at Site 915 and Site 918 have a quite uniform composition similar to depleted Icelandic tholeiites. Two major successions are defined: the older Continental Succession and the younger Oceanic Succession. The Continental Succession comprises the Lower and Middle Series lavas at Site 917, and the Oceanic Succession comprises the Uppers Series lavas at Site 917 and the main SDRS series lavas at Sites 915 (and Site 990) and Site 918. The Oceanic Succession is separated from the Continental Succession by an unconformity and a thin sediment horizon. The Oceanic Succession shows strongly decreasing (to absent) continental contamination, a primary melting depth extending to a shallower level (spinel field), and, apart from the initial picritic Site 917 Upper Series, a much more uniform composition and a less depleted source than the Continental Sucession. The age of the reversely magnetized Continental Succession is approximately 61-60 Ma, possibly slightly older, and is related to magnetic Chron C26r (possibly C27r). The main part of the Oceanic Succession is 56-53 Ma (magnetic Chron C24r), with the oldest part extending into C25r. Except for six of the youngest lava flows in the Lower Series, the Continental Succession had a depleted (ambient asthenosphere?) mantle source, and magmas underwent considerable fractionation in crustal magma chambers. The Oceanic Succession, except for the initial Site 917 Upper Series, had a slightly less depleted mantle source. Tentative estimates of eruption rates vary from 1/11 k.y. within the Continental Succession to 1/670 yr within the main SDRS wedge. Likewise, the total magmatic flux is estimated to vary from (maximum) $0.225 \mathrm{~km}^{3} / \mathrm{k} . \mathrm{y} . / \mathrm{km}$ rift length (Continental Succession) to $1.333 \mathrm{~km}^{3} / \mathrm{k} . \mathrm{y} . / \mathrm{km}$ rift length (Oceanic Succession). Excess temperature of the mantle source is estimated to approximately $100^{\circ} \mathrm{C}$ for both successions. The main SDRS wedge is interpreted to represent fully igneous crust that formed rapidly (half-rate $4.4 \mathrm{~cm} / \mathrm{yr}$ ) along a subaerially exposed rift like the present-day Iceland rift zone. The featheredge of the SDRS overlying continental crust subsided significantly later than the main wedge that was transgressed by a shallow sea almost immediately after its formation. Erosion of the rift flank (Continental Succession) was (locally) deep shortly after breakup, and the Eocene witnesses erosion of a former, large and deeply weathered volcanic cover over the continental margin. Regional, kilometer-scale margin uplift took place after breakup, possibly during the mid-Tertiary, where significant crustal exhumation of the continental margin is taking place. However, the onset of North Atlantic and Greenland glaciation recorded at Site 918 and dated to approximately $7 \mathrm{Ma}$ led to further erosion of remnants of the formerly much wider volcanic cover of the inner shelf and coastal region. Significant thinning of the continental crust takes place within an only $25-\mathrm{km}$-wide zone seaward from Site 917. Thinning of the upper crust took place through seaward rotation of fault blocks along landward-dipping normal faults extending to mid-crustal depths much like the structures displayed by the East Greenland coastal flexure and dike swarm. Significant parts of the crustal thinning took place between eruption of the Continental and Oceanic Successions. We explain observations on mantle sources, primary melting depths, timing and location of volcanism, and magmatic flux rates with a model invoking a plume head in the order of $10^{8} \mathrm{~km}^{3}$ in volume, and rapidly ascending (in the order of $\mathrm{m} / \mathrm{yr}$ ) and spreading (in the order of $0.5 \mathrm{~m} / \mathrm{yr}$ ) below the lithosphere within an upper mantle with a non-Newtonian (nonlinear) rheology. Upon impact, the former, more bulbous-shaped, plume head is spreading into a thin (in the order of $50 \mathrm{~km}$ thick) sheet with a diameter of about $2000 \mathrm{~km}$ and filling in the topographic relief at the bottom of the lithosphere. This was completed by $61 \mathrm{Ma}$ and caused regional North Atlantic uplift evident at Site 917 (basal unconformity between Lower Series and pre-rift sediments). Decompression melting of plume material and frictionally heated ambient asthenosphere (and possible lithosphere) take place at thin lithospheric spots. Opening of the Northeast Atlantic rift takes place at or shortly after magnetic Chron C25n (56 Ma) and allows the hot plume sheet to spread along the rift, which becomes floored by hot mantle for as much as $2700 \mathrm{~km}$ from south of Greenland to the Barents Sea. The developing plate boundary offers a continuously growing lithospheric thin spot. Plume mantle is flowing, decoupled from the underlying asthenosphere, at rates estimated to between 11 and $22 \mathrm{~cm} / \mathrm{yr}$, laterally toward the rift and fills the void between the parting plates. The relief at the bottom of the lithosphere thus controls the thickness of the plume layer below the SDRS rift, and allows for a melting column of the order $100 \mathrm{~km}$ thick, which, at $15 \%-20 \%$ degree of melting, is able to generate the close to 20-km-thick SDRS crust at the observed high rates. Eventually, the plume reservoir is exhausted, and normal temperature asthenosphere mantle starts to rise (and melt) below the rift.
\end{abstract}

${ }^{1}$ Saunders, A.D., Larsen, H.C., and Wise, S.W., Jr. (Eds.), 1998. Proc. ODP, Sci. Results, 152: College Station, TX (Ocean Drilling Program).

${ }^{2}$ Danish Lithosphere Centre, Østervoldgade 10, L, 1350 Copenhagen K, Denmark. larsenhc@ dlc.ku.dk

${ }^{3}$ Department of Geology, University of Leicester, Leicester LE1 7RH, United Kingdom.

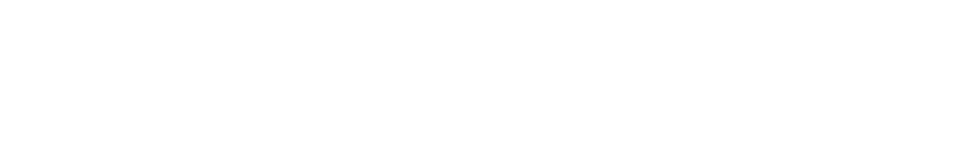




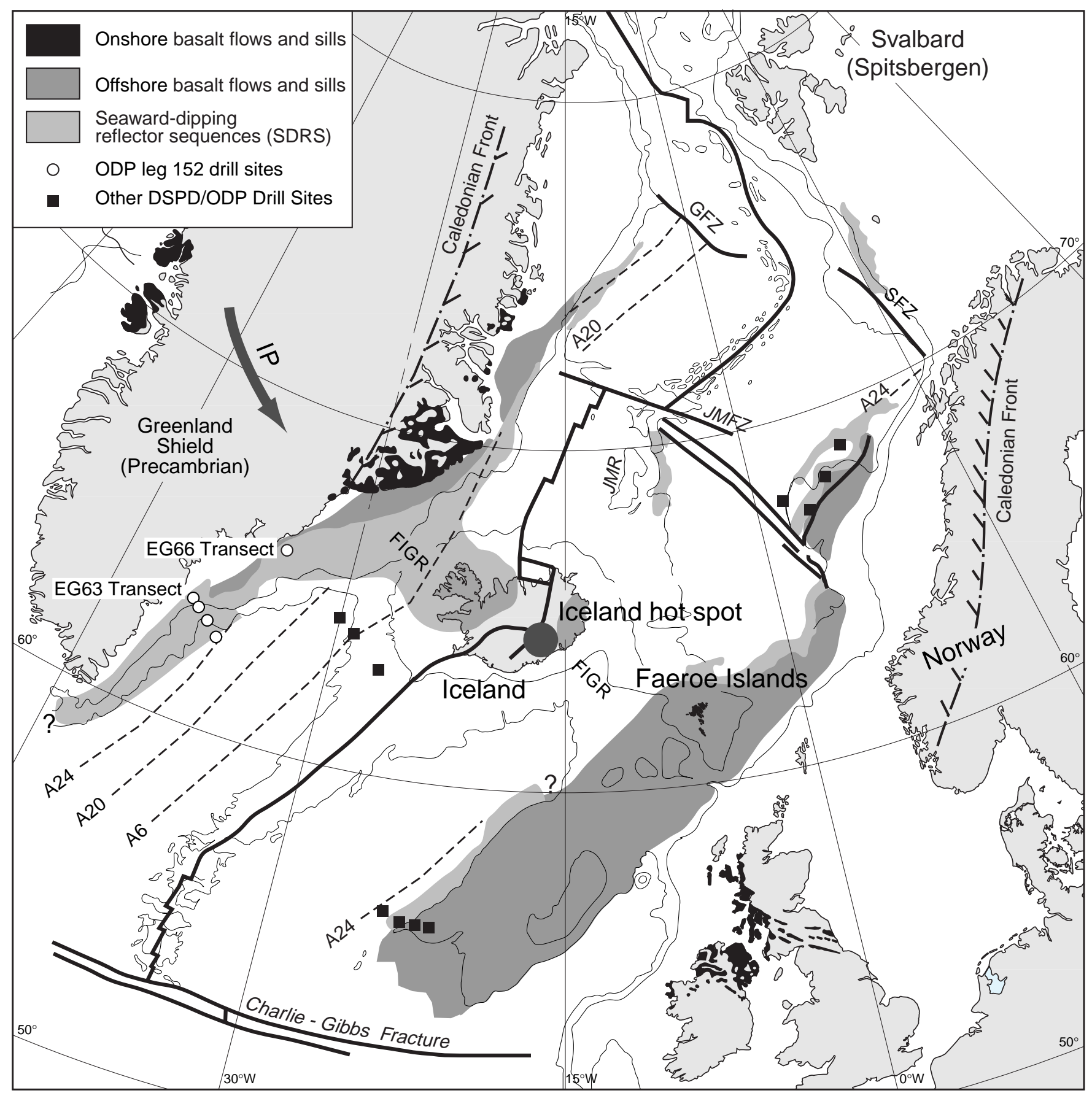

Figure 1. Distribution of seaward-dipping reflector sequences and continental flood basalts of the North Atlantic Volcanic Province. ODP and DSDP drill sites along the volcanic rifted margins of the North Atlantic are shown. Subaerially erupted basalts show flood basalt structure landward of the inferred continent/ ocean boundary and have a SDRS structure seaward of the boundary. Also shown is the present position of the Iceland plume (hot spot) and its former path below Greenland (arrow) according to Lawver and Müller (1994). Other models show a more north-south-directed plume track than shown here (e.g., Vink, 1984). FIGR = Faeroe-Iceland-Greenland Ridge. JMR = Jan Mayen Ridge. JMFZ = Jan Mayen Fracture Zone. SFZ = Senja Fracture Zone. GFZ = Greenland Fracture Zone. Selected seafloor-spreading anomalies shown by dashed lines.

\section{INTRODUCTION}

Ocean Drilling Program (ODP) Leg 152 to the southeast Greenland Margin resulted in the first successful penetration on a volcanic rifted margin through the early rift volcanics and into pre-rift sediments. Furthermore, it sampled the volcanic development into unequivocally (Icelandic-type) oceanic crust. A number of specialty papers (all this volume) report the detailed investigations of the recov- ered material and associated geophysical studies. The present paper attempts to summarize these observations and to discuss the implications of these within the broader framework of the southeast Greenland rifted margin and the early Tertiary breakup of Greenland from Northwestern Europe (Fig. 1). The paper provides a summary of the setting of the study area, structural and tectonic observations (Cambray, this volume), geophysical observations (Planke and Cambray, this volume; Larsen et al., Chap. 39, this volume), subsidence (and 


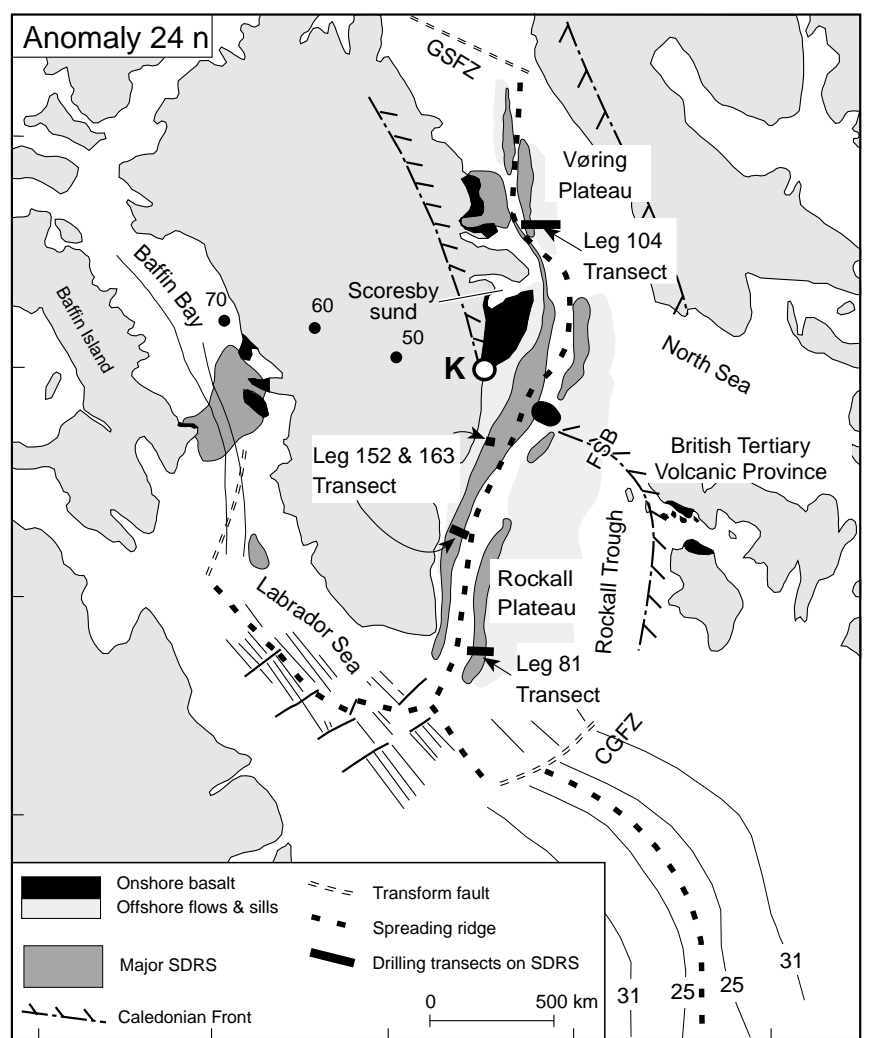

Figure 2. Plate reconstruction of the North Atlantic after formation of the main SDRS wedges in the northeast Atlantic Ocean at magnetic Chron C24n time (53 Ma). Spreading started in the northeast Atlantic at, or shortly after, C25n (56 Ma) and within the northern Labrador Sea at C26r/C27n (61 Ma). Extensive pre-breakup rifting took place inside the area of Caledonian deformation, along the West Greenland Margin and within the Rockall Trough. However, the scarcity and the thin development of pre-rift sediments below outliers of rift lavas along the southeast Greenland coast suggest limited rifting and basin formation within this cratonic area prior to breakup. Leg 152 drilling penetrated the SDRS lavas on the southeast Greenland mid-shelf and recovered presumed Upper Cretaceous to lower Paleocene marine pre-rift sediments. This may suggest more extensive basin formation along the southeast Greenland Margin than previously assumed. Annotated circles mark the location of the Iceland plume (stem) at 70, 60, and $50 \mathrm{Ma}$ according to Lawver and Müller (1994). K = Kangerlussuaq Fjord. GSFZ = GreenlandSenja Fracture Zone. CGFZ $=$ Charlie Gibbs Fracture Zone. FSB $=$ Faeroe Shetland Basin.

uplift) of the margin (Larsen, Saunders, Clift, et al., 1994b; Clift et al., 1995), the volcanic development with time, and the location of the continent-ocean transition (COT; Fitton et al., Chap. 28; Fram et al.; Thy et al.; Sinton and Duncan; Larsen et al., Chap. 39; L.M. Larsen, Chap. 27; and Werner et al.; all this volume). The main subjects addressed are rifting history, crustal structure, and location of the COT; emplacement models for the thick volcanic section forming the seaward-dipping reflector sequence (SDRS), magma fluxes, and the possible role and mechanics of a hot mantle plume in the process of rifting and breakup of this margin. The possible correlation (mainly on geochemical grounds) of early Tertiary North Atlantic plume activity to the Neogene activity of the Iceland plume is addressed in an accompanying synthesis paper (Saunders et al., this volume) and by Saunders et al. (in press).

Subsequent to Leg 152, major geological investigations on shore and ODP Leg 163 offshore were carried out in 1995 (Brooks et al., 1996; M. Larsen et al., 1996; Pedersen et al., 1997; Duncan, Larsen,
Allan, et al., 1996). Moreover, deep seismic profiling across this margin was performed in 1996 (Dahl-Jensen et al., 1997).

\section{OPENING OF THE NORTHEAST ATLANTIC}

The setting of the Leg 152 margin transect within the northeast Atlantic region is shown in Figure 1 (present day) and in Figure 2 (early Tertiary pre-drift). The main features of the opening of northeast Atlantic ocean basin are summarized in the following. The reader is referred to Larsen et al. (1994a), Larsen and Duncan (1996), and Saunders et al. (this volume; in press) for more comprehensive reviews of the region, selection of and objectives of the southeast Greenland drill sites, and for a more extensive bibliography.

Final breakup of the North Atlantic between Greenland and Europe took place (Talwani and Eldholm, 1977; Srivastava and Tapscott, 1986) in the early Tertiary during magnetic Chron 24r (late Paleocene; approximately 56-53 Ma according to Cande and Kent, 1995, and Berggren et al., 1995).

The line of opening was fairly straight and continuous from the former triple junction south of Greenland and northward to the present position of Iceland (Fig. 2), and spreading continued during the Cenozoic in a regular, symmetric pattern along this axis (Reykjanes Ridge). Breakup in this southern region took place within the eastern margin of the Greenland Precambrian shield and craton (Fig. 2), and outcrop of pre-breakup sediments along the coast are scarce and thin (few tens of meters) and only known to continue south to about $66^{\circ} \mathrm{N}$ (see Larsen, 1980, for review). They occur as thin layers between the Precambrian basement and the locally preserved outliers of rift-related lavas.

Rapid propagation of the spreading from the south of Greenland and northward to the Greenland-Senja Fracture Zone (Fig. 1) during magnetic Chron C24r has been suggested by Larsen (1988), but is an unresolved question. North of the present-day position of Iceland the line of opening had a more winding trend, possibly with some minor transform offsets. The subsequent spreading history involves jumping or migration of parts of the spreading axis (e.g., Larsen, 1988) and formation of a number of important transform faults (Tjørnes and Jan Mayen Fracture Zone north of Iceland; Fig. 1). Breakup in this northern zone took place in continental lithosphere reworked during the Caledonian orogeny (Silurian) and subsequently affected and stretched by a number of rifting events of Devonian through Cretaceous age (e.g., Skogseid et al., 1992). In this northern area rift lavas were extruded over (and partly through) deep basins (e.g., Larsen and Marcussen, 1992).

Between this northern and southern zone an aseismic ridge connects the Faeroe platform with Iceland and the East Greenland shelf. This ridge, known as the Faeroe-Iceland-Greenland Ridge (Fig. 1; FIGR), is generally accepted as the track of the Iceland hot spot. The latter has been explained by a deep-seated mantle plume (e.g., Vogt, 1983; Schilling et al., 1983; Schilling, 1991; Hémond et al., 1993; Thirlwall et al., 1994). However, when the Iceland plume came into existence and where it impacted below the North Atlantic region is not known. Lawver and Müller (1994) envisaged a very long-standing plume, possibly dating back to the Permo-Triassic, whereas others (e.g., Campbell and Griffiths, 1990; Hill, 1991) suggest a close association between plume impact and breakup. Between these opposing views White and McKenzie (1989, 1995), Kent et al. (1992), Saunders et al. (in press) invoke the possibility that a plume head could incubate for some time prior to breakup. However, regardless of the time of plume initiation, models of absolute plate movements (for a review, see Lawver and Müller, 1994, or Saunders et al., in press) suggest that the center of the Iceland plume (stem) drifted from the west or northwest below central Greenland during the Late Cretaceous and Paleocene. According to Lawver and Müller (1994) the plume center arrived below the spreading axis east of Greenland (paleo-Reykjanes Ridge) during the Eocene, and has gradually drifted 
east of the general trend of the Reykjanes Ridge. It is now located within the southern end of the eastern Iceland rift zone (Fig. 1). The eastern rift zone of Iceland has migrated eastward several times in the Neogene (Saemundsson, 1986), suggesting that the present plume stem to some extent controls the position of the rift zone. The plume stem recently has been mapped by seismic tomography (Wolfe et al., 1997).

Large volumes of basaltic lavas were erupted during continental breakup. Some of the lavas form continental flood basalts such as the West Greenland plateau basalts (Clarke and Pedersen, 1976; Gill et al., 1992; Holm et al., 1993), East Greenland plateau basalts (L.M. Larsen et al., 1989) and the Faeroe basalts (Waagstein and Hald, 1984 ) and their offshore equivalents. Another, and perhaps most voluminous, part of the subaerially erupted breakup lavas is found along the submerged parts of the rifted margin where they form thick $(5 \mathrm{~km}$ or more) sequences of lavas with a dip (increasing with depth) toward the ocean. The latter are known as the seaward-dipping reflector sequences (SDRS) and show a seismic stratigraphic structure very reminiscent of the stratigraphic structure observed in the Tertiary lava plateaux of western and Eastern Iceland (e.g., Mutter et al., 1982; Larsen, 1984; Pálmason, 1986; Larsen and Jakobsdóttir, 1988).

\section{A New Class of Rifted Margins?}

The transient excessive volcanism, the lack of deep basin development during breakup (i.e., subaerial volcanism along the initial rift axis), and the excessive thickness of the igneous crust forming along the COT (typically around $20 \mathrm{~km}$; Larsen and Jakobsdóttir, 1988; Spence et al., 1989; Fowler et al., 1989; Morgan et al., 1989; Zehnder et al., 1990; Barton and White, 1995) make these margins very different from rifted margins like the Bay of Biscay margin (Roberts and Montadert, 1979) and the Galicia margin (Boillot et al., 1989). Along the latter margins the seismically defined crust around the COT is thin (12-8 km or less) and comprises serpentinized mantle exhumed during rifting and breakup (e.g., Sawyer, Whitmarsh, Klaus, et al., 1994; Whitmarsh et al., 1996).

The margins around the northeast Atlantic therefore seem to form a distinct class of margins informally named volcanic rifted margins. Globally many rifted margins seem to possess the same features as observed along the northeast Atlantic margins (see Coffin and Eldholm, 1994). A number of studies (e.g., Brooks, 1973; Mutter et al., 1982; Eldholm, Thiede, Taylor, et al., 1987, 1989; Larsen and Jakobsdóttir, 1988; White and McKenzie, 1989, 1995; Thompson and Gibson, 1991; Hill, 1991; White, 1992) have pointed out the possible connection between the type of structures found along the North Atlantic volcanic rifted margins and the Iceland mantle plume, and hence, that hot mantle plumes may play an active role in continental breakup.

\section{Detailed Setting of Drilling Transect}

The setting of the southeast Greenland drilling transect is shown in Figure 3 (map view) and in a generalized cross section (Fig. 4). The southeast Greenland SDRS is about $130 \mathrm{~km}$ wide and typically 5 to $7 \mathrm{~km}$ thick along the drilling transect (Fig. 3). It is broadening to the north toward the Iceland-Greenland Ridge and may also be thicker in this area (Larsen and Jakobsdóttir, 1988). It can be divided into a thick main part (main SDRS), and a landward part (the so-called featheredge) where the sequence thins and eventually tapers off toward the continent.

The main SDRS terminates seaward where the smooth tops of the SDRS (i.e., top volcanic basement) change into a rough, hummocky, and seismically (semi) opaque basement surface around seafloor spreading anomaly C24n (see original seismic data in Larsen and Jakobsdóttir, 1988; and Larsen, Saunders, Clift, et al., 1994b, and figs. 7 and 8 in Larsen et al., Chap. 39, this volume). The seaward termination of the main SDRS was interpreted by Larsen and Jakobsdóttir (1988) as the transition to (shallow) submarine volcanism and forma- tion of oceanic crust closer to normal thickness. However, seawarddipping reflectors continue seaward at depth for some distance below the hummocky basement surface. Following the interpretation of Larsen and Jakobsdóttir (1988) this suggests that even in this location, the deeper (older) part of the crust formed above sea level, but subsided below sea level before the youngest, topmost part of the extrusive cover was emplaced.

As shown by Figures 3 and 4, the featheredge of the SDRS seems to onlap more or less directly onto the Precambrian crystalline crust along the southeast Greenland Margin. Larsen (1978) suggested that an offshore continuation of the East Greenland coastal dike swarm and flexure zone (e.g., Wager and Deer, 1938; Nielsen, 1978; Myers, 1980; Nielsen and Brooks, 1981; Bird et al., 1988; Myers et al., 1993; Klausen et al., 1996) is present within this onlap zone. Seismic data (Larsen, 1990) and Leg 152 drilling confirmed the presence of a seaward-dipping flexure zone including rift lavas on top of continental crust. However, no sheeted dike complex was recovered during Leg 152 , but this may be present at a deeper, and in particular, more seaward position (Larsen et al., Chap. 39, this volume).

\section{STRATIGRAPHY AND AGE OF THE SDRS}

One of the primary goals of Leg 152 was to determine the age, nature and development with time of the volcanics within the SDRS, the emplacement mechanism and environment of these volcanics, and the amount and nature of possible intravolcanic sediments. Existing borehole data from other North Atlantic SDRS (Fig. 1; "Introduction" chapter in Larsen, Saunders, Clift, et al., 1994b) show that at least the inner (featheredge) part of the SDRS off Hatton Bank (conjugate to southeast Greenland) and on the Vøring Plateau (Eldholm, Thiede, Taylor, et al., 1987, 1989) consisted of subaerially erupted, mainly basaltic lava flows intercalated with minor sediment of fluviatile to shallow-water origin. The limited pre-Leg 152 data from the more seaward and main bodies of the North Atlantic SDRS show evidence of subaerial as well as (shallow?) submarine volcanism (Roberts, Schnitker, et al., 1984).

\section{General Volcanic Stratigraphy}

The southeast Greenland SDRS was drilled and sampled at three sites (Sites 917, 915, and 918), and drilling just reached the top of the SDRS at Site 916 within a small graben structure (Fig. 4). Site 914 terminated well above the volcanic basement, and Site 919 was drilled to only shallow depth within the postrift sediments to address paleoceanographic questions. Detailed core descriptions and the initial stratigraphic subdivisions were presented by Larsen, Saunders, Clift, et al. (1994b) and minor modifications to the igneous stratigraphy by Demant et al. (1995).

A total of $920.3 \mathrm{~m}$ of lava section was drilled during Leg 152. Site 917 penetrated early lava succession $(779 \mathrm{~m}$; minimum 91 lava flow units) and bottomed in pre-rift sediments. Site 915 penetrated $20.1 \mathrm{~m}$ into basement (two flow units), and Site 918 penetrated $120.7 \mathrm{~m}$ into basement (18 flow units) below $1189.4 \mathrm{~m}$ of postrift sediments. Site 916 bottomed in a volcaniclastic sediment breccia (lahar?) with large lava clasts suggesting close proximity of the basement and active volcanism and/or tectonism in the area (Werner et al.; Holmes; both this volume). At the three basement sites, the volcanic basement was overlain by fluviatile or shallow-water sediments (in part conglomeratic). Almost all recovered flow tops show red weathering, but thin soil or sediment (fluviatile) horizons have developed only between a few of the flow units. Thus, all recovered lava flow units are interpreted as subaerially erupted and deposited lava flows (Larsen, Saunders, Clift, et al., 1994b; Holmes; L.M. Larsen, Chap. 27; Demant; Planke and Cambray; all this volume). The overall stratigraphy of the drilled volcanic sequence is shown in Figure 5.

We have not formally defined members, formations, and groups, but instead have identified "series" and "successions." The way we 


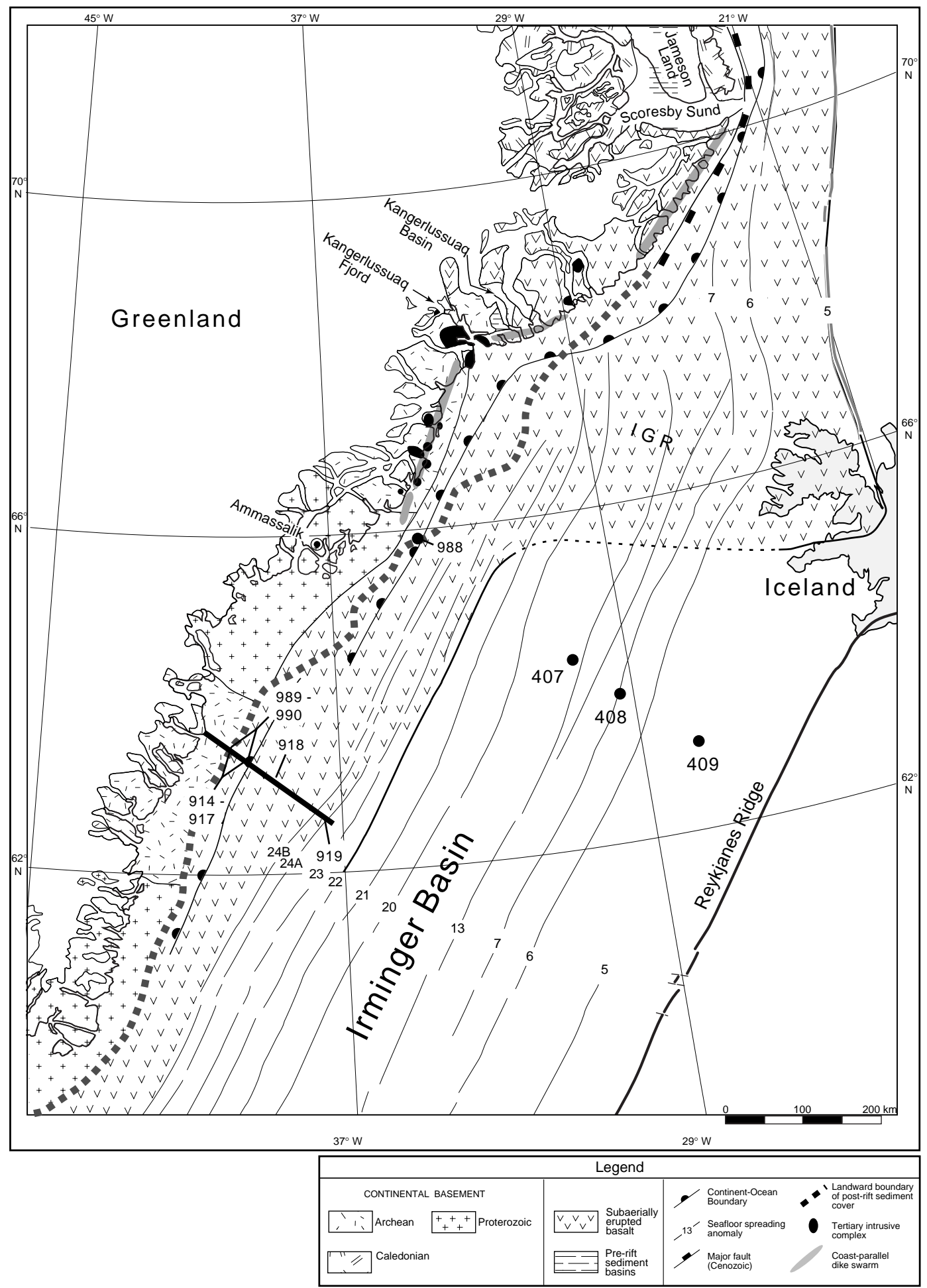

Figure 3. ODP sites (Sites 914-917, 988-990) and DSDP sites (Sites 407-409) along the southeast Greenland Margin. Note that basement is of Caledonian age north of the Kangerlussuaq Fjord, and that thick basin development is present below the flood basalts in this northern region. The Leg 152 drilling transect is located within an Archean segment of the southeast Greenland craton (e.g., Kalsbeek, 1989; Blichert-Toft et al., 1995). The subaerially erupted basaltic lavas show SDRS structure (including northwestern Iceland) seaward of the continent/ocean boundary (COB). The COB on this map is drawn within the center part of the continent-ocean transition (COT). The SDRS wedge is typically 5-6 km thick, possibly as thick as $10 \mathrm{~km}$ below the Iceland-Greenland Ridge (Larsen and Jakobsdóttir, 1988). The East Greenland flood basalts show similar thickness toward the coast east and northeast of the Kangerlussuaq Basin (Pedersen et al., 1997). IGR = Iceland-Greenland Ridge. Modified from Larsen (1990). 

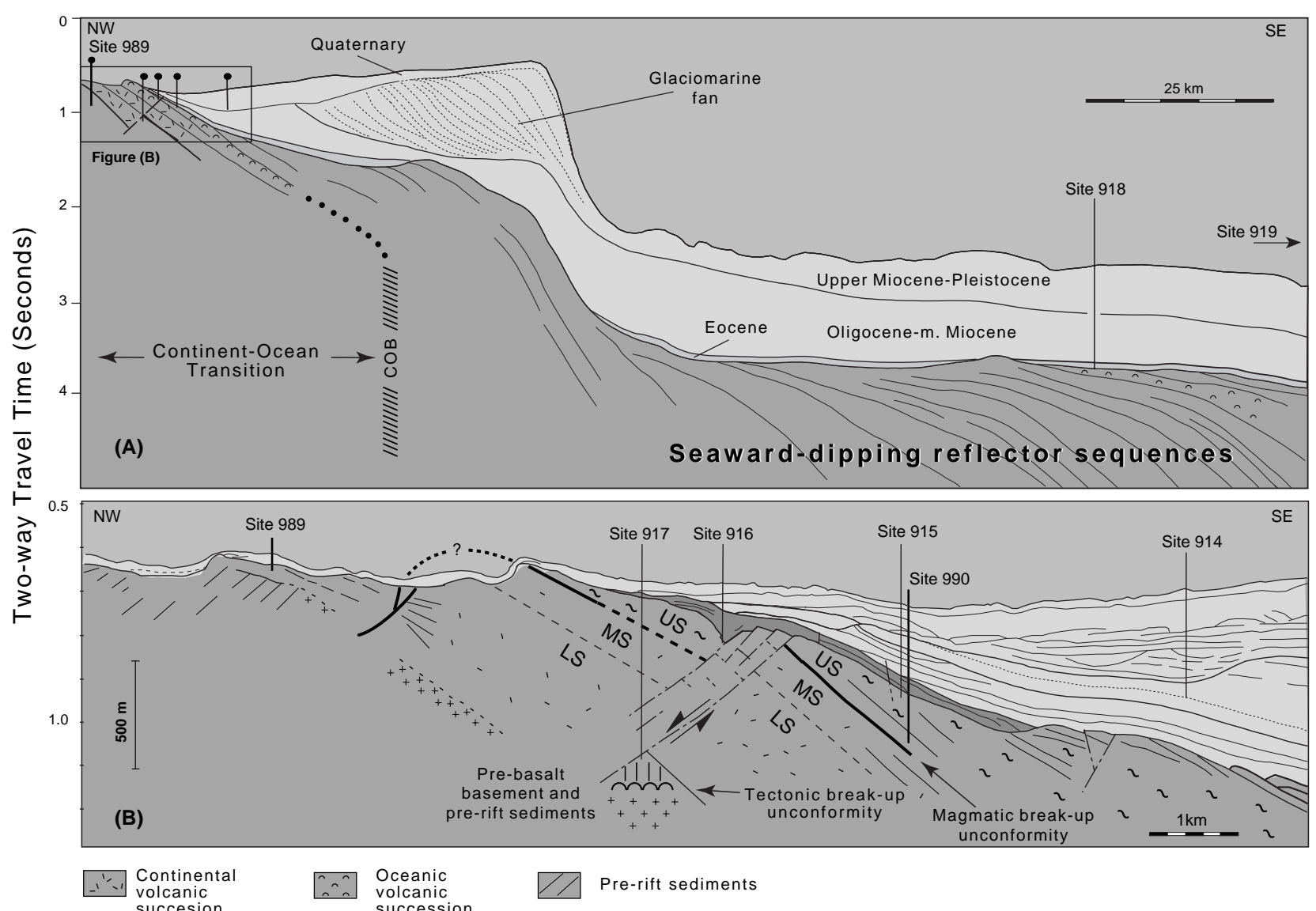

Figure 4. A. Location of the drill sites and shallow crustal structure along the drilling transect with location of (B) marked (box). B. Details of the inner (shelf) drill sites. $\mathrm{COB}=$ Continent/ocean boundary (outer limit of continental crust); note that the COB marked in Figure 3 is within the center of the continent-ocean transition. LS = Site 917 Lower Series. MS = Site 917 Middle Series. US = Site 917 Upper Series. Lavas recovered at Sites 915 and 990 belong to the main SDRS series and are different from the site Upper Series although the opposite is indicated by this cross section. However, the deepest part of Site 990 must have been close to the top of the Site 917 Upper Series. An unconformity exists between the Site 917 Middle and Upper Series and marks the magmatic breakup unconformity (see main text). A deeper-lying unconformity was found near the bottom of Hole 917A at the base of the Site 917 Lower Series lavas (see also Fig. 13). This is interpreted as reflecting plume arrival and early uplift (tectonic breakup unconformity), but may not be a strong tectonic unconformity as originally interpreted (Larsen, Saunders, Clift, et al., 1994b). Lavas recovered at Site 989 resemble lavas from Sites 915 and 990 (Duncan, Larsen, Allan, et al., 1996), suggesting, quite enigmatically, that the magmatic breakup unconformity somehow is below (dashed line with question mark) the recovered section at Site 989.

have used this terminology makes series similar to formation and succession similar to group. The drilled lavas are divided into a lower Continental Succession and an upper Oceanic Succession. The two successions are separated by an unconformity and a thin sediment horizon (Fig. 5 and Larsen, Saunders, Clift, et al., 1994b; Cambray; Holmes; Sinton and Duncan; Fitton et al., Chap. 28; all this volume). In addition to the two main successions, a few dikes within the lavas at Site 917 and a sill within postrift sediments at Site 918 were drilled.

\section{Continental Succession}

The Continental Succession comprises (from bottom to top) the Lower and Middle Series lavas (636.6 m) within Hole 917A as defined by Larsen, Saunders, Clift, et al. (1994b). Although Site 917 bottomed in pre-rift sediments, the lowermost part of the Continental Succession (i.e., Lower Series) was either incompletely, or not at all, sampled due to normal faulting and stratigraphic omission in the lower part of the borehole. Thus, several hundred meters of the Lower Series (444.0 m drilled) may be missing at Site 917 (discussed in detail later in this chapter). The Lower Series comprises (sparse) picrite, olivine basalt, and basalt with systematic changes in $\mathrm{MgO}$ content reflecting fractionation in crustal magma chambers (decreasing $\mathrm{MgO}$ ) and input of new primitive melt (increasing $\mathrm{MgO}$ )(Fitton et al.,
1995). The average flow thickness is $12.7 \mathrm{~m}$, and pahoehoe lavas dominate over aa lavas. The Middle Series (192.6 m drilled) comprises more evolved basalts, dacites, and acid tuffs. The average flow thickness is $8.1 \mathrm{~m}$, and flows show almost exclusively aa morphology. The Continental Succession is interpreted to have been derived from a depleted mantle, except for six enriched flows toward the top of the Lower Series (Fitton et al., Chap. 28, this volume).

The Continental Succession shows considerable contamination with continental lithosphere. A development from lower crustal contamination (granulite facies gneiss) to upper crustal contamination (amphibolite facies) is reported by Fitton et al. (Chap. 28, this volume) to take place within the Lower Series. However, because both granulite and amphibolite facies gneiss are exposed along the coast only $50 \mathrm{~km}$ west of Site 917, this observation does not necessarily imply a systematic shallowing with time of the crustal magma chambers. However, Larsen et al. (Chap. 39, this volume), on the basis of deep seismic data, suggest that a fairly intact continental crust with a lower and upper part existed below the Continental Succession prior to final breakup. Eruption sites for the Continental Succession are not known and cannot be determined on the basis of their dip (Cambray, this volume) as it is possible for the SDRS that erupted from a downdip source (Larsen and Jakobsdóttir, 1988; and below). However, a single, thin dike of similar composition and age as the Lower Series 
Summary of lava stratigraphy

Sites $915,917,918$ and 990

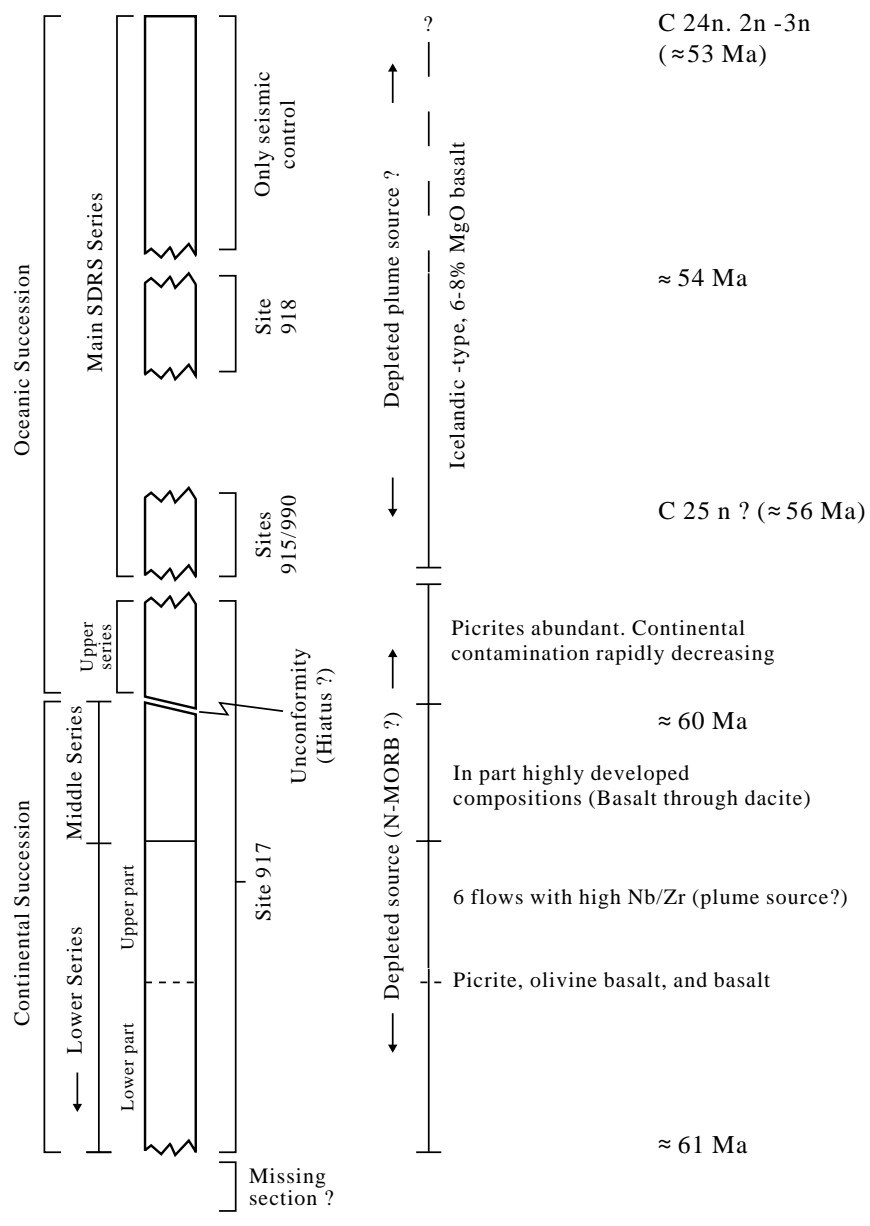

Figure 5. Summary of lava stratigraphy. More detailed descriptions are given in the main text and in Larsen, Saunders, Clift, et al. (1994b), Fitton et al. (Chap. 28, this volume), Demant (this volume), L.M. Larsen et al. (Chap. 27, this volume), and Saunders et al. (this volume). The formal grouping of series into the Continental and Oceanic Successions and the definition of the Main SDRS Series are presented in this paper.

lavas has been sampled on shore along the coast (60.7 Ma; M. Storey, pers. comm., 1997) and shows that magmatism of this type and age (ca. 60-61 Ma) took place in a fairly wide area.

\section{Oceanic Succession}

The Oceanic Succession comprises (from bottom to top) the Upper Series lavas as defined in Hole 917A and the younger lavas of Site 915 and 918, informally referred to as the "main SDRS series" lavas; all SDRS lavas seaward of Site 918 (i.e., younger than Site 918 lavas) are also tentatively included in the main SDRS series. The Site 917 Upper Series (lower part of Oceanic Succession; $141.5 \mathrm{~m}$ drilled) comprises picrite and olivine basalt with rapid and large variations in $\mathrm{MgO}$ content. The average flow thickness is $4.2 \mathrm{~m}$ and the majority show pahoehoe morphology. The main SDRS series (Sites 915, 918, and more recently, Leg 163 Site 990) comprises mainly tholeiitic basalts with very little compositional variation. The average flow thickness is $6.7 \mathrm{~m}$ at Site 918 . Aa flow morphology is dominant in the top part of Site 918 and is replaced downward with a dominance of pahoehoe flows. The same observation was made at Site 990 (Duncan, Larsen, Allan, et al., 1996).
The upper boundary of the oceanic succession is defined as the transition into submarine volcanism. This is interpreted from seismic data to take place around Site 919 (Fig. 3). The oceanic succession thus represents the main SDRS wedge and forms a 5- to 7-km-thick layer of extrusives. However, the total stratigraphic thickness of the main SDRS series is much larger because of its shingled internal structure (Larsen and Jakobsdóttir, 1988). This succession evidently is incompletely sampled. However, the available data, including data from Site 990 very close to Site 915 (Duncan, Larsen, Allan, et al., 1996), do indicate a very uniform composition and depositional environment throughout the main SDRS wedge. A contributing factor to this apparent compositional monotony could be the limited penetration into the main SDRS wedge, which allowed us to sample only those lavas that escaped far from the active rift zone and were not deeply buried by later eruptions. This biased sampling may not represent the full spectrum of magmatic activity within the former active rift zone (see also Fitton et al., Chap. 28, this volume; and Larsen, Saunders, Clift, et al., 1994b).

The Oceanic Succession was fed from an actively spreading rift system located $20-30 \mathrm{~km}$ downdip of the updip termination (toplap) of the SDRS lavas (Fig. 6). The source for the main part of the Oceanic Succession was a depleted mantle initially interpreted to represent normal mid-ocean-ridge basalt (N-MORB) mantle (Larsen, Saunders, Clift, et al., 1994b). However, based on Nb/Y-Zr/Y relationships, Fitton et al. (Chap. 28, this volume) show that the source of the main SDRS series resembles depleted Icelandic mantle and is less depleted than the asthenospheric source of the picritic Upper Series and the (dominant) mantle source for the Continental Succession. Based on multi-element rare-earth-element (REE) relationships, Fram et al. (this volume) further suggest that the picritic Upper Series shows a parallel presence of a depleted asthenospheric mantle and, with upward-increasing strength, the depleted Icelandic-type mantle from which the overlying main SDRS series was sourced. Both Fram et al. (this volume) and Fitton et al. (Chaps. 28 and 29, this volume) conclude that increasing degree of melting and source depletion took place with time during formation of the Upper Series. Thus, minor light-rare-earth-element (LREE) enrichment during eruption of the Upper Series, as proposed by Fram et al. (this volume), would tend to be diluted and, in addition, difficult to distinguish from continental crustal contamination (Saunders et al.; Fitton et al., both this volume).

A marked decrease in continental contamination of the magma source is seen within the Upper Series, but low levels of contamination are still visible within the early part of the main SDRS series (Site 915 lavas). Pristine, uncontaminated compositions are only found at Site 918 (Fitton et al.; Saunders et al., both this volume).

\section{Late Volcanism}

Volcanism following formation of the igneous basement is only represented by one igneous unit located $9.3 \mathrm{~m}$ above the top of the main SDRS at Site 918. It has a composition notably different (LREE enriched) from the main SDRS series and is interpreted to reflect offaxis, low-degree of melting (Fitton et al., Chap. 28; Fram et al., this volume). This unit probably is a sill or invasive flow (see also section on age determinations below). An off-axis volcano is located 5-10 $\mathrm{km}$ west of Site 918 (Larsen, Saunders, Clift, et al., 1994b) and is suggested as a possible source of this igneous unit. By the time of sill emplacement, the spreading centre was located $\sim 100 \mathrm{~km}$ to the east of the volcano. Apart from volcanic ash layers within the postrift sediments, no younger volcanism is recorded.

The younger volcanic ash layers, in particular those within the Neogene sediments, are interpreted to have an Icelandic origin (Lacasse et al.; Werner et al.; Clift and Fitton, all this volume; summary in Saunders et al., this volume). However, it is likely that the volcanogenic component of the Eocene sediments overlying the SDRS at Site 918 (Larsen, Saunders, Clift, et al., 1994b; Werner et al., this volume) represents volcanism along the rift axis located 
Figure 6. The principle of seaward-dipping reflector sequence (SDRS) formation (see also Fig. 11). The interpretation builds on the model for crustal accretion in Iceland (Pálmason, 1986). A. Initiation of SDRS formation during breakup and formation of the featheredge of the SDRS onlapping onto continental crust. In the case of the southeast Greenland COT, the Continental Succession is to be considered part of the continental crust. When spreading continues, a wide zone of SDRS crust forms. The model implies a down-dip, narrow and fairly linear, subaerially exposed volcanic source that stayed above sea level during the entire SDRS formation (Larsen and Jakobsdóttir, 1988). B. Kinematic model of formation of SDRS-type crust. Loading stress highest in center. Flow lines in dashed line and resultant stratigraphic structure in solid lines with age progression shown in m.y. Sheeted dike complex at the bottom of the lava pile. Modified from Pálmason (1986).

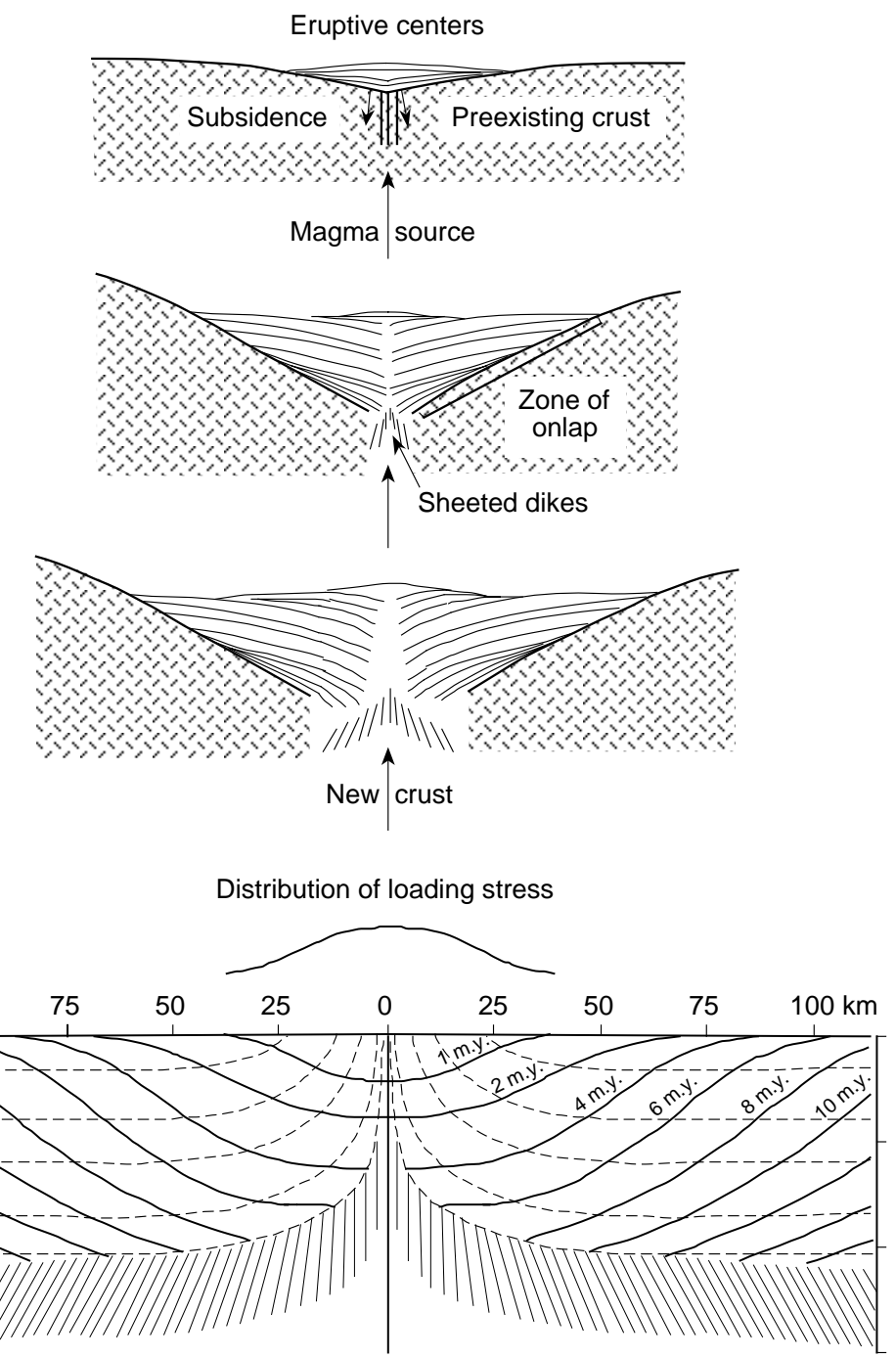

southeast of Site 918 during times where this was approaching, and eventually subsiding below sea level.

\section{Age Determinations}

We now discuss the timing of the eruption of the various parts of the continental and oceanic succession and the late stage volcanism. Constraints on the age of the igneous units are provided from interpretation of seafloor spreading anomalies (Fig. 7), paleomagnetic analyses of the drill core, biostratigraphy and palynology of sediments overlying or interbedded with the igneous units, and most importantly, from detailed ${ }^{40} \mathrm{Ar}-{ }^{39} \mathrm{Ar}$ whole rock and mineral age determinations. We here synthesize these different studies and propose a consistent geochronological framework. A summary of age determinations from the igneous basement along other northeast Atlantic margins is presented by Saunders et al. (this volume).

A Chron $24 \mathrm{r}$ age of the upper (younger) part of the oceanic succession was determined by Larsen and Jakobsdóttir (1988) on the basis of well-developed seafloor spreading anomalies C23n to C24n seaward of the SDRS. This implies that the middle (older) and lower (oldest) part of the SDRS must be of C24r (or older) age.

Shipboard paleomagnetic data showed continuously reversed remanent magnetism for all lava units drilled during Leg 152 (i.e., at Sites 915, 917, 918); a few units were indeterminable and another few showed low negative to low positive inclinations. The latter were interpreted as possibly representing the cryptochrons of Cande and Kent (1992; 1995). Shipboard paleomagnetic data were interpreted as representing only one magnetic chron-Chron $24 \mathrm{r}$, which is close to 3 m.y. long (ca. 53-56 Ma) and comprises as many as 11 cryptochrons ("Summary and Principal Results" chapter in Larsen, Saunders, Clift, et al., 1994b).

However, surprisingly old ages in the range 60-62 Ma (C26r to C27r) were obtained from both the Lower and Middle Series by ${ }^{40} \mathrm{Ar}-$ ${ }^{39} \mathrm{Ar}$ step heating age determinations of both whole rock and mineral separates (feldspars). Accordingly, the shipboard assignment of the whole volcanic phase to Chron $24 \mathrm{r}$ was incorrect. Also drilling during Leg 163 recovered normally magnetized flows also indicating the presence of at least one normal polarity interval (Duncan, Larsen, Allan, et al., 1996).

In the following we refer to the geomagnetic time scale of Cande and Kent (1995). The reader is referred to the specialty papers (this volume) for details of standards and constants used for the radiometric age determinations. Such interlaboratory variations can cause minor corrections in the order of a few hundred k.y. to be applied on the reported ${ }^{40} \mathrm{Ar}-{ }^{39} \mathrm{Ar}$ ages in order to get an entirely uniform set of data for comparison with the geomagnetic time scale.

\section{Site 917}

The setting of this site suggests that the igneous basement here must be of very oldest C24r age or older (i.e., approximately $56 \mathrm{Ma}$ or older). The overlying sediments are of middle Eocene age (i.e., younger than approximately $48 \mathrm{Ma}$; Wei, this volume) and together with paleomagnetic data (Ali and Vandamme, this volume) suggest 


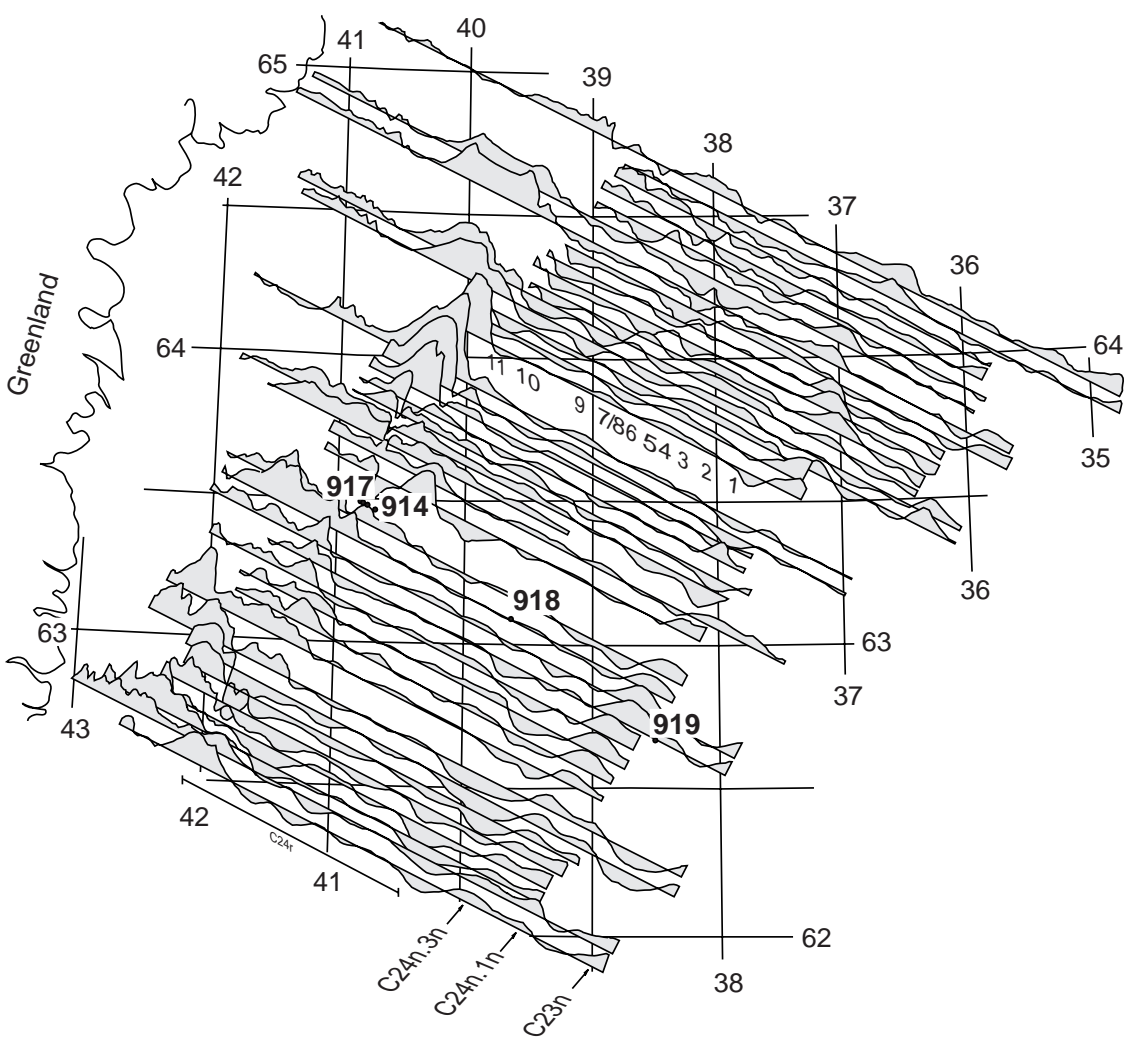

Figure 7. Aeromagnetic data over the study area. Interpretation of Chrons C23, C24n, and C24r and of cryptochrons 1-11 within C24r from Larsen, Saunders, Clift, et al. (1994b). that a significant hiatus exists on top of the igneous basement at Site 917. Radiometric age determinations of the igneous units therefore provide the only firm age constraints on the Site 917 lavas, with additional constraints provided by possible magnetic cryptochrons within the reversely magnetized lava series (Vandamme and Ali, this volume).

The radiometric ages presented by Sinton and Duncan (this volume) show a spread of analytically reliable age determinations from 60 to 62 Ma within the Lower and Middles Series (no age determinations where obtained from the Upper Series). The older ages generally arises from the Middle Series and the younger ages from the Lower Series, and hence, are not stratigraphically consistent. Several lines of evidence suggest that the younger ages around 60 to $60.5 \mathrm{Ma}$ from the Lower Series are likely to be the most accurate, and that the older ages from the Middle Series are slightly too high (excess argon and/ or pre-magmatic feldspar xenocrysts within the analyzed mineral populations; see Sinton and Duncan, this volume, and Werner et al., this volume).

First, the land-based paleomagnetic work (Vandamme and Ali, this volume) has confirmed and extended the shipboard determinations including verification of stable, low inclination events interpreted as representing magnetic cryptochrons at two different stratigraphic levels within, respectively, the top of the Lower Series and close to the top of the Middle Series (Table 1). The total range of radiometric ages brackets over two possible reverse magnetic chrons: Chron 26r and Chron 27r (Cande and Kent, 1992, 1995). However, because no normal intervals are recorded and because no cryptochrons are known from Chron 27r, eruption of the Lower and Middle Series during Chron 26r (60.9-57.9 Ma) is therefore concluded. Furthermore, the seven cryptochrons within $\mathrm{C} 26 \mathrm{r}$ follow a cryptochronfree interval of 0.5 m.y. early within C26r (i.e., 60.9-60.4 Ma; Cande and Kent, 1995). We therefore interpret the two paleomagnetic lowinclination events as the two oldest cryptochrons C26r.7n and C26r.6n within C26r (Table 1).

The above interpretation based on the step heating ${ }^{40} \mathrm{Ar}-{ }^{39} \mathrm{Ar}$ age determinations by Sinton and Duncan (this volume) and paleomagnetic data (Vandamme and Ali, this volume) is supported by ${ }^{40} \mathrm{Ar}-$
${ }^{39} \mathrm{Ar}$ age determinations of single grain crystals from the Middle Series tuffs (Werner et al., this volume). Two intervals (bottom and near top of the Middle Series) yielded stratigraphically consistent ages $(60.5 \pm 0.2 \mathrm{Ma}$ and $60.3 \pm 0.2 \mathrm{Ma}$, respectively) that correlate extremely well with the ages concluded above (Table 1).

Thus, nearly all reliable ${ }^{40} \mathrm{Ar}-{ }^{39} \mathrm{Ar}$ data and paleomagnetic data can be reconciled by accepting an age of the drilled Lower Series lavas from 60.9 to $60.3 \mathrm{Ma}$ (i.e., lower part of C26r including cryptochron C26r.7n). The age of the Middle Series accordingly would span the C26r.7n-C26r.6n interval (i.e., 60.3 Ma to 60.1 Ma). Though we correlate the interpreted cryptochrons within Hole 917A with C26r.6-7n, it is possible that one or two cryptochrons were not recorded within the lava succession or were hiding in the few indeterminate flows at Site 917. If so, the age of the Middle Series could be slightly younger, though this would develop a rapidly growing conflict with several good ${ }^{40} \mathrm{Ar}-{ }^{39} \mathrm{Ar}$ age determinations (Table 1 , and Sinton and Duncan, this volume); the latter suggests that the two recorded cryptochrons actually are C26r.6n and C26r.7n.

The maximum age of the early (recovered) part of the Lower Series is interpreted to be younger than magnetic Chron C27n (60.9 Ma) because no normal magnetic intervals were found. However, simple downward extrapolation (assuming constant eruption frequency) of the above ages results in a model age of ca. 61.1 Ma for the oldest recovered section (i.e., older than the $60.9 \mathrm{Ma} \mathrm{C} 27 \mathrm{n} / \mathrm{C} 26 \mathrm{r}$ transition). This might suggest a slight increase in eruption frequency downhole Site 917 Lower Series. However, if a significant part of Lower Series was not recovered by Hole 917A due to stratigraphic omission (normal faulting) within its lower part (see later discussion), volcanism therefore could have started within, or prior to, C27n.

Independent evidence for approximately $61 \mathrm{Ma}$ old magmatism recorded with Hole 917A has been obtained by a precise age determination $(60.7 \pm 0.4 \mathrm{Ma})$ of a dike from the coastal region close to Site $917\left({ }^{40} \mathrm{Ar}-{ }^{39} \mathrm{Ar}\right.$ step heating by M. Storey, unpubl. Danish Lithosphere Centre data). The dike has a composition similar to the Lower Series, but any closer stratigraphic correlation is not possible, and this age, despite its very reliable nature, does not further detail the age of the initial volcanism. 
The above interpretation is consistent with the majority of observations. However, if we ignore the interpretation of the magnetic cryptochrons, and if we accept what Sinton and Duncan (this volumes) consider the most reliable age determination of the Middle Series tuff, then the entire Lower and Middle Series (i.e., Continental Succession) could be as old as C27r. This is not considered likely, but on the other hand, cannot be rejected. However, even if this was the case, it would not necessarily shift initiation of volcanism more than perhaps $0.5 \mathrm{~m} . \mathrm{y}$. back in time, but in a regional context, this could also be significant (e.g., correlation with West Greenland volcanism; Storey et al., 1996).

\section{Site 918}

The volcanic basement at Site 918 is located within a broad magnetic low landward of seafloor spreading anomaly C24n.3n (Fig. 7) and therefore must be of $\mathrm{C} 24 \mathrm{r}$ (or older) age. Additional age constraints are provided by biostratigraphic and paleomagnetic age determinations of sediments overlying the igneous basement and by a precise radiometric age determination of an igneous unit within the lowermost sediments. Radiometric age determination of a lava from within the volcanic basement has a significant analytical uncertainty.

Consistent with the setting of Site 918, interpretation of shipboard and shore-based paleomagnetic and biostratigraphic data shows that the lavas drilled at Site 918 and the overlying first few meters of sediment are of $\mathrm{C} 24 \mathrm{r}$ age and are followed by sediments of $\mathrm{C} 24 \mathrm{n}$ age (Fig. 8; Ali and Vandamme; Wei; and Spezzaferri, all this volume).

The youngest volcanism at Site 918 is represented by a basaltic unit sampled $9.3 \mathrm{~m}$ above the volcanic basement (Fig. 8). It probably is a sill (Larsen, Saunders, Clift, et al., 1994b), but its age (51.9 Ma; Sinton and Duncan, this volume) is almost identical to the age of the surrounding sediments (Fig. 8; Wei; Spezzaferri, both this volume). This supports an interpretation of the unit as a flow that intruded downward into partly unconsolidated sediments (invasive flow).

The sill is interpreted to be reversely magnetized (Ali and Vandamme, this volume) and thus can be correlated with C23r (51.8$52.3 \mathrm{Ma}$ ). This is consistent with the interpretation of the normally magnetized host sediments as representing C24n (Fig. 8; Ali and Vandamme, this volume). These normally magnetized sediments are replaced downward by $6 \mathrm{~m}$ of reversely magnetized sediments overlying the basaltic SDRS basement (reversely magnetized, C24r) in which no normal polarity intervals were recorded within the recovered section (Fig. 8). Despite the high number of cryptochrons (11) within $\mathrm{C} 24 \mathrm{r}$, none of these are recorded in the sedimentary section. However, it is not evident that cryptochrons will be detectable within slow sedimentation rate sediments like these (Larsen, Saunders, Clift, et al., 1994b). One shallow inclination event within the SDRS lavas at Site 918, which could represent a cryptochron, is reported by Larsen, Saunders, Clift, et al. (1994b). According to the interpretation of seafloor spreading anomalies in the region (Fig. 7) Site 918 is located

Table 1. Summary of selected and consistent age determinations.

\begin{tabular}{lll}
\hline \multicolumn{1}{c}{ Upper Series } & Middle Series & \multicolumn{1}{c}{ Lower Series } \\
\hline Lava units 1-33 & Lava units 34-57 & Upper part (lava units 58- 73 ) \\
No age information & Unit 35: & Units 61-74: \\
& $60.1 \mathrm{Ma}^{*}$ & $60.4 \mathrm{Ma}^{*}$ \\
Unconformity: & $60.3 \pm 0.2 \mathrm{Ma}^{\dagger}$ & Unit 71: \\
No age information & $60.8 \pm 1.3 \mathrm{Ma}^{\dagger}$ & $60.4 \mathrm{Ma} \pm 0.7 \mathrm{Ma}^{\dagger}$ \\
& Unit 57: & \\
& $60.5 \pm 0.2 \mathrm{Ma}^{\dagger}$ & Lower part (lava units 74-92) \\
& & Units 74-92 (bottom): \\
& & $<60.9 \mathrm{Ma}^{*}$
\end{tabular}

Notes: Paleomagnetic data $\left({ }^{*}\right)$ are from Vandamme and Ali (this volume), ${ }^{40} \mathrm{Ar}-{ }^{39} \mathrm{Ar}$ age data from Sinton and Duncan $(\dagger)$ and from Werner et al. ( $\ddagger$ ) (both this volume). See main text for discussion and selection of age data. Data from Sinton and Duncan are plateau ages. Data from Werner et al. are isochron ages. between C24r.5n to C24r.6n age, and hence, if a cryptochron is present in the lava section, this should be C24r.6n (54.5 Ma according to Cande and Kent, 1995).

With average sedimentation rates of $1 \mathrm{~cm} / \mathrm{k} . \mathrm{y}$. the $6 \mathrm{~m}$ of reversely magnetized sediments on top of the lavas (Fig. 8) represent ca. 600 k.y. This would imply an age of approximately 54.0 Ma for the uppermost lavas at Site 918 , and this age is consistent with the age (54.5 Ma) of the possible cryptochron deeper in the lava section (Fig. 8). It is also consistent with an ${ }^{40} \mathrm{Ar}-{ }^{39} \mathrm{Ar}$ isochron age of approximately 54 Ma (Sinton and Duncan, this volume), but this age determination has large analytical uncertainty $( \pm 1.8 \mathrm{~m} . \mathrm{y}$.) and is not considered a reliable age by itself.

Whereas all the above age constraints can be interpreted in a consistent way, Jolley (this volume), based on palynological data, suggests that the reverse magnetization of the oldest, postvolcanic sediments should be referred to Chron C23r. This would imply a hiatus between the lavas and the overlying sediments from around mid $\mathrm{C} 24 \mathrm{r}$ time to mid C23r time (Fig. 7), but there is no evidence in favor of such a hiatus (Holmes, this volume). Furthermore, it would also imply that reverse magnetization of the igneous unit (sill) within overlying normally magnetized sediments must be of Chron C22r (or younger) age, and this is not supported by the ${ }^{40} \mathrm{Ar}-{ }^{39} \mathrm{Ar}$ age reported by Sinton and Duncan (this volume).

\section{Lower part of Site 918}

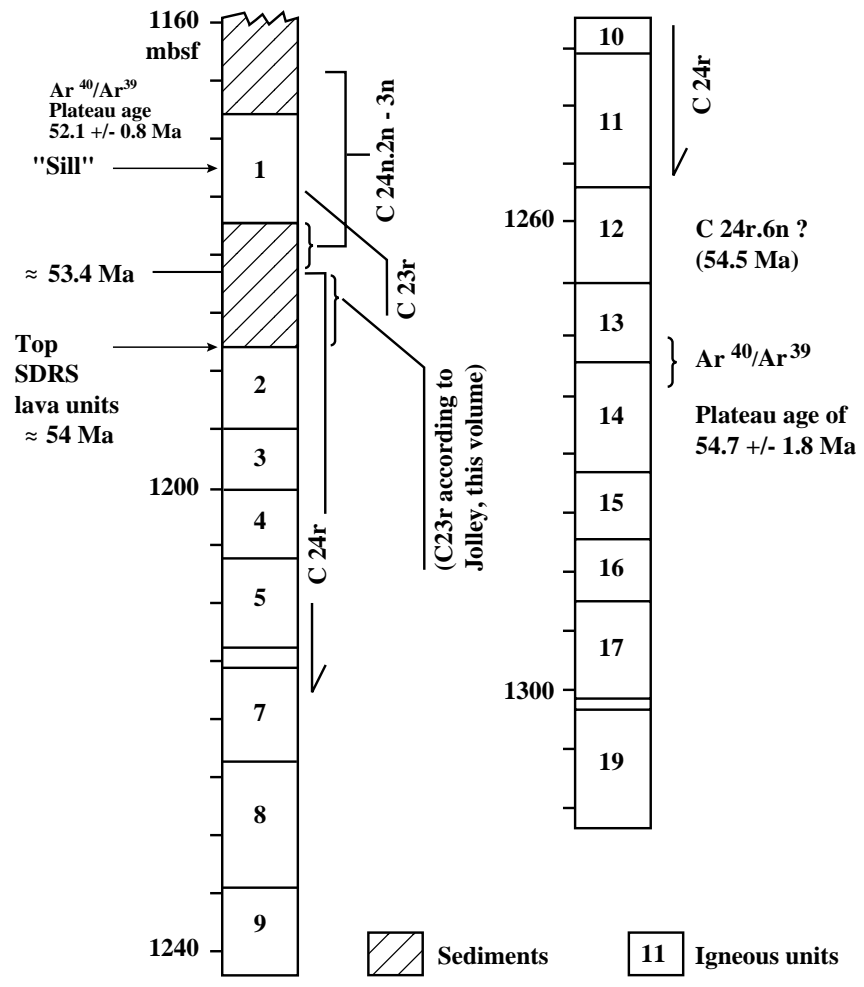

Figure 8. Simplified stratigraphy of the lower part of Site 918 . The age of the top of the basement is based on downward extrapolation from the boundary $\mathrm{C} 24 \mathrm{n} .3 \mathrm{n} / \mathrm{C} 24 \mathrm{r}$ located $6 \mathrm{~m}$ above the basement, and assuming sedimentation rates of $1 \mathrm{~cm} / \mathrm{k} . \mathrm{y}$. (Larsen, Saunders, Clift, et al., 1994b). Aeromagnetic data (Fig. 7) suggest that lavas of C24r.6n (54.5 Ma) could be present at depth. A possible occurrence of this cryptochron in the core is shown, and correlates with an analytically poorly constrained ${ }^{40} \mathrm{Ar}^{39} \mathrm{Ar}$ age (54.7 Ma). A precise age of an igneous unit (sill) within the post-rift sediments supports the paleomagnetic interpretation of these, but Jolley (this volume) suggests a C24r age for the oldest sediments. See also main text for discussion, and Figure 9 for compilation of age determination data. 


\section{Site 916}

This site is located in a small graben or half-graben zone associated with the a normal fault zone and hole 916A bottomed just above or at the sediment-lava interface (Fig. 4). Thus, deposition and preservation of early sediments is more likely to have taken place than at Site 917, where a significant hiatus is present above the basement. A basal volcanogenic sediment interpreted to be of synvolcanic origin (Larsen, Saunders, Clift, et al., 1994b; Holmes; Werner et al.; both this volume) is present below marine sediments of Eocene age (Wei, this volume). According to Jolley (this volume) the basal sediment is likely to be of the same age as the sediment overlying the Site 918 lavas (i.e., of C23r or C24r age).

\section{Age Determinations and Spreading Rates}

Figure 9 shows all age data as a function of offset from the seaward end of the main SDRS sequence. All the interpreted cryptochrons fall on a straight line corresponding to a spreading half-rate of $4.4 \mathrm{~cm} / \mathrm{yr}$. Spreading rate decreases across Chron C24n-23n (approximately $2.3 \mathrm{~cm} / \mathrm{yr}$ ), but is still high compared to the values characterizing spreading throughout the Tertiary (typically 1 to $1.5 \mathrm{~cm} / \mathrm{yr}$ ). Critical for the fit of the spreading rate line through Sites 918, 915, and 990 is the age of the lavas from the latter two sites. A normal magnetic polarity interval was found within the two topmost igneous units at Site 990 and to be followed downsection by reversely magnetized lavas (Duncan, Larsen, Allan, et al., 1996). This normally magnetized unit could represent either Chron C25n or C26n. Unpublished age determinations from Site 990 (R. Duncan and C. Tegner, pers. comm., 1996) are only consistent with an age of C25n. Further- more, if the normally magnetized units were assigned to C26n, one might expect C26r cryptochrons to be present at deeper levels within Site 990, but no such intervals were found (Duncan, Larsen, Allan, et al., 1996). We therefore correlate the Site 990 normally magnetized units with C25n. This places Site 915/990 just above the straight line fitting the C24r interval across the main SDRS (Fig. 9). This would suggest that full-scale spreading at high rate was achieved just after extrusion of Site 915/990 lavas, that is, shortly after C25n. Initiation of (Icelandic-type) seafloor spreading at this time is consistent with the lack of seafloor spreading Anomaly C25n along the northeast Atlantic rifted margins (e.g., Srivastava and Tapscott, 1986). A transition to steady-state spreading at this location (spatially) is also consistent with the observed volcanic stratigraphy and compositional development.

Magnetic Chron C25n was also tentatively indicated by Schönharting and Abrahamsen (1989) to be present within the oldest (featheredge) part of the Vøring Plateau SDRS (see also Saunders et al., this volume; in press).

The age data of Figure 9 show that a major gap spanning in age from the upper part of $\mathrm{C} 26 \mathrm{r}$ to uppermost part of C25r (i.e., approximately 60-56 Ma) is located between Site 917 (Lower and Middle Series) and Sites 915/990. Within this time interval the Site 917 Upper Series lavas, the reversely magnetized lavas of the deeper parts of Sites 915/990, plus a thin, nonrecovered section in between these two recovered sections formed (Fig. 4; no stratigraphic overlap between Site 990 and 917). Thus, only 400 to $500 \mathrm{~m}$ of lavas accumulated in this almost 4 m.y. long period. As discussed below, there is considerable evidence against infrequent eruptions and low accumulation rates during formation of this interval. It is therefore most likely that a true hiatus is present within this interval.

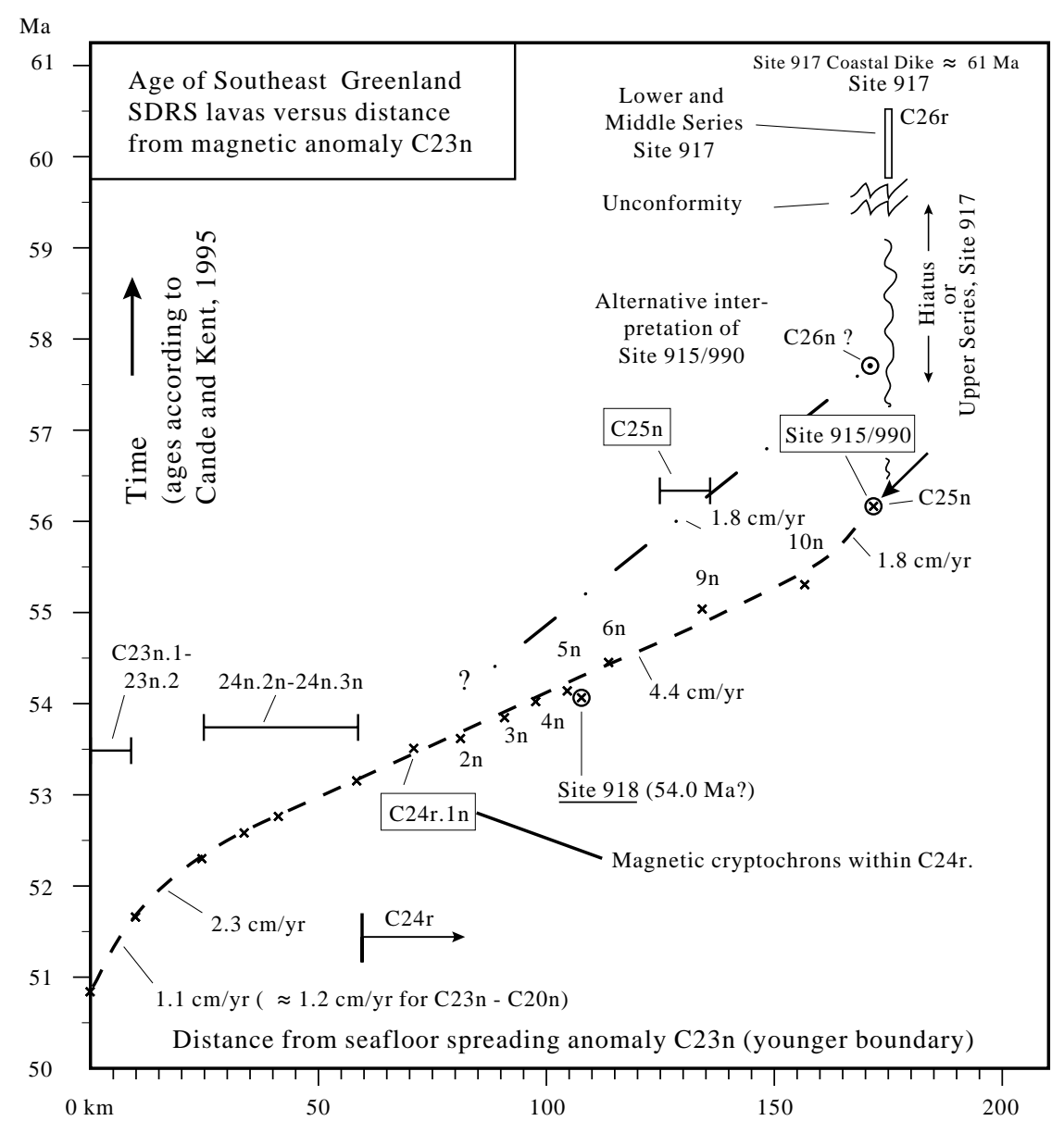

Figure 9. Compilation of age determinations along the drilling transect. Chrons C23n, C24n, C24r, and cryptochrons $\mathrm{C} 24 \mathrm{r} .1 \mathrm{n}-10 \mathrm{n}$ are from interpretation of aeromagnetic data. Age of Site 918 lavas from ${ }^{40} \mathrm{Ar}-{ }^{39} \mathrm{Ar}$ age determinations and paleomagnetic data from the drill core. C25n is based on clear normal-polarity findings within the Site 990 drill core (Duncan, Larsen, Allan, et al., 1996). Ages of coastal dike and the Lower and Middle Series lavas from ${ }^{40} \mathrm{Ar}-{ }^{39} \mathrm{Ar}$ age determinations. If normal polarity lavas at Site 990 are interpreted as representing $\mathrm{C} 26 \mathrm{n}$, a much poorer fit of the age vs. distance data is obtained, and one would expect C25n to have shown as a well-developed magnetic anomaly similar to $\mathrm{C} 24 \mathrm{n}$. The preferred interpretation suggests start of spreading at ca. $56 \mathrm{Ma}$ followed by acceleration of spreading to ca. $55.3 \mathrm{Ma}$, high (constant) rates of spreading $(4.4 \mathrm{~cm} / \mathrm{yr})$ until ca. $52.3 \mathrm{Ma}$, and then abating rates of spreading approaching the typical $1.2 \mathrm{~cm} / \mathrm{yr}$ value applying to the early Tertiary Reykjanes Ridge. See text for further discussion and data sources. 


\section{Stages and Possible Breaks in Volcanism}

Based on its compositional development, the Continental Succession can be considered a two-stage development, with the Lower Series lavas representing an initial phase, and the lavas and tuffs of the Middle Series representing a waning phase with eruption of increasingly evolved magmas (Larsen, Saunders, Clift, et al., 1994b; Fitton et al., Chap. 28, this volume). Consistent with this, a few thin sediment horizons and intensified flow top weathering are seen toward the top of Lower Series of Site 917 (Larsen, Saunders, Clift, et al., 1994b; Cambray, this volume; Holmes; this volume). Also, a general decrease in flow thickness is seen upsection through the Continental Succession. An acidic tuff layer and sediment horizon are seen just below the top of the Middle Series. A sediment horizon $(67 \mathrm{~cm}$ recovered) is located between the Middle and Upper Series (i.e., transition from the Continental to the Oceanic Succession) and suggests a significant break in volcanism. Following the first two flows of the picritic Upper Series, a soil horizon was found suggesting a short break. Except for the sediment horizon between the Continental and Oceanic Successions, all these features are interpreted to represent only short, temporary reductions in an otherwise remarkably continuous and vigorous volcanic activity.

The unconformity between the Site 917 Middle and Upper Series (i.e., boundary between the Continental and Oceanic Successions) was interpreted by Larsen, Saunders, Clift, et al. (1994b) to represent the most significant break in volcanism and to reflect final breakup (magmatic breakup unconformity). The unconformable nature of this horizon is suggested by the difference in tectonic tilt and dip direction and the marked change in magmatism across this horizon (Cambray, this volume; Le Gall and Cambray, 1996; Saunders et al., this volume). In addition rapid thinning of the lithosphere and a marked lowering and progressive decrease of continental crustal contamination are interpreted to take place during eruption of the Site 917 Upper Series lavas (Fram et al., this volume).

\section{A Hiatus Between the Continental and Oceanic Successions?}

We have shown that a time gap of 3-4 m.y. must be present between the Middle Series and the main SDRS series. One likely possibility is that most of this time interval is located within the unconformity between the Continental and Oceanic Series. Another possibility is that a hiatus may be present within a nonrecovered break in volcanism between the Upper Series and the main SDRS series. A third possibility, namely that no major hiatus exists, and hence, that the picritic Site 917 Upper Series and the Site 915/990 lavas (oldest part of the main SDRS series) were associated with very low accumulation rates and infrequent eruptions, is not considered likely because of the lack of deep weathering and/or sediment horizons within these lavas.

No definitive evidence in support of either one of the above possible scenarios exists. The following discussion is therefore based partly on circumstantial evidence, partly on model-driven evidence.

Based on sediment thickness and lack of mature soil formation (i.e., kaolinite) within the thin fluviatile sediment (river bed) at the Site 917 unconformity, Holmes (this volume) argues that the hiatus between the Middle and Upper Series cannot be significantly longer than $0.5 \mathrm{~m}$.y. However, no constraints on the original thickness of the sediment or the setting of this particular deposit exist. Furthermore, while lack of a mature clay mineralogy (e.g., kaolinite) in a soil profile would indicate a limited time interval, lack of kaolinite within a (sandy) river bed deposit could be caused by several factors: nondeposition in this particular facies, or simply, a sediment source region from which mature clay already was removed following an extended time of erosion and fairly deep exposure.

In support of deep erosion and a stillstand in volcanism is the occurrence of Lower Series lithologies and continental lithologies within the basal conglomeratic sediment at Sites 915/990 (Duncan, Lar- sen, Allan, et al., 1996). This shows that prior to the formation of the main SDRS series (i.e., before C25n) the Continental Succession was already deeply eroded to a degree that perhaps even the entire Continental Succession had been removed at Site 989 (Duncan, Larsen, Allan, et al., 1996). As shown in Figure 4, these observations are most simply explained by a significant unconformity and hiatus below the Site 917 Upper Series, though the possibility also exists that it could be located within the section missing between the cores of Site 917 and Sites 915/990, that is, within the lowermost part of the Oceanic Succession.

Model-driven arguments can be put forward in favor of a hiatus between the Continental and Oceanic Successions as well as within the lowermost part of the Oceanic Succession.

The latter possibility is pointed out by Saunders et al. (this volume) referring to the extensive occurrence of highly picritic lavas within earliest phases of volcanism in West Greenland, the British Isles, and southeast Greenland (Lower Series at Site 917). Thus, if the main hiatus is located stratigraphically above the Upper Series picrites at Site 917, these picrites would fall into this phase of early picritic volcanism. Geodynamically, this interpretation places initial emplacement of anomalous (hot) mantle below the continental lithosphere and collapse of this lithosphere to near spreading conditions into the same, early time interval (ca. 62-60 Ma), followed by a significant slowdown or hiatus in magmatism before final plate separation.

Opposing this idea, one could argue that because the Site 917 Upper Series records the collapse of the continental lithosphere and associated shallowing of the melting region, this development is more straightforward to link with the onset of active plate separation and rapid accumulation of lavas (i.e., main SDRS series at Sites 915/990 and 918). This interpretation implies a two-stage scenario: (1) initial volcanism caused by emplacement of an anomalous (hot) mantle below the continental lithosphere (Lower Series) followed by starvation of volcanism (Middle Series); (2) renewed and vigorous, decompression-aided volcanism reflecting collapse of the continental lithosphere due to extension and plate separation (Upper Series).

In this context, it is important to note that the high seismic velocity of the lower crust below the SDRS shows that during the entire period of margin formation, Mg-rich melts were abundant, but mostly were stalled and accumulated within the lower crust (e.g., Larsen et al., Chap. 39, this volume; Kelemen and Holbrook, 1995). The timing of picrite extrusion is therefore not necessarily reflecting unique mantle conditions, but could also reflect tectonic conditions allowing rise of dense, $\mathrm{Mg}$-rich melts.

\section{Magma Fluxes}

\section{Continental Succession}

For the present purpose we assume that the Continental Succession had a total thickness of $1 \mathrm{~km}$ (just over $636.6 \mathrm{~m}$ recovered at Site 917 ) and that it originally covered a $150-\mathrm{km}$-wide zone. Current evidence for such a formerly wide distribution of the Continental Succession is restricted to the single dike of the same age and composition as the Lower Series found on shore about $50 \mathrm{~km}$ west of Site 917 (see above section on age determinations). Because the COT is located approximately $25 \mathrm{~km}$ east of Site 917 , the total width of the Continental Succession could have been $75 \mathrm{~km}$ at the Greenland margin; we assume simple symmetry with the conjugate Hatton Bank margin. Current age determinations indicate extrusion of the entire succession in less than $1 \mathrm{~m} . \mathrm{y}$. The original melt column must have been thicker than $1 \mathrm{~km}$, as the lavas of the Lower Series likely underwent fractionation and cumulate material was left behind (Thy et al., this volume; see also Fram and Lesher, 1997). We assume a 1.5-km-thick melting column. This results in a productivity of $0.225 \mathrm{~km}^{3} / \mathrm{k} . \mathrm{y} . / \mathrm{km}$ rift length. This figure is likely to be close to a maximum estimate and could be significantly lower (by a factor 5?). In particular, the former width across the rift of this succession may be (grossly) overestimat- 
ed. However, it could also be larger (twice as large?), if duration of the volcanism was significantly less than $1 \mathrm{~m} . \mathrm{y}$. and/or if considerably more material was left behind in the crust or below this.

\section{Oceanic Succession}

The main SDRS series represents full igneous crust approximately $20 \mathrm{~km}$ thick including both feeder dikes, magma chambers, and fractionated material within the middle and lower crust, and the melt column is therefore assumed to equal the crustal thickness. A minimum 100-km-wide zone of this type of crust formed in 3 m.y. off southeast Greenland and, if symmetry with the conjugate Hatton bank is assumed, this translates into a productivity of $1.333 \mathrm{~km}^{3} / \mathrm{k} . \mathrm{y}$./ $\mathrm{km}$ rift length. This estimate of magmatic flux is considerably more reliable than the flux estimated for the Continental Succession and is roughly six times higher than this. The main uncertainties are related to the average thickness of the SDRS crust and the degree of symmetry between the two conjugate margins.

Thick SDRS development is found to the south of Greenland approximately $1300 \mathrm{~km}$ south of the Iceland plume track (Hopper et al., 1996; Larsen et al., 1995), and northward (e.g., White, 1992) to the former Greenland-Senja Fracture Zone (Fig. 1). The total length of the rift zone along which this type of crustal accretion took place was therefore approximately $2700 \mathrm{~km}$. Thus, multiplying the entire rift length with this productivity results in a total magma productivity out of the mantle (Iceland plume head?) of $3.6 \mathrm{~km}^{3} / \mathrm{yr}$ during the first few million years of plate separation (i.e., 56-53 Ma). This number must be considered a maximum estimate because the southeast Greenland SDRS wedge seems particularly wide and well developed and offset from the Iceland plume track by only $600 \mathrm{~km}$. If only the extrusive part is considered, the number would be approximately one third of this, or $1.2 \mathrm{~km}^{3} / \mathrm{yr}$. Similar order of magnitude figures were obtained by Coffin and Eldholm, 1994; Eldholm and Grue, 1994; White and McKenzie, 1995).

\section{EMPLACEMENT, SUBSIDENCE, AND UPLIFT Eruption Frequency}

According to the chronostratigraphic framework established above, the 72 flow units of the Lower and Middle Series (Continental Succession) were laid down in $\sim 0.8 \mathrm{~m}$.y., which is equivalent to 1 flow $/ 11$ k.y. Obviously, this estimate entirely depends on the correctness of the estimated time interval. However, if the drilled part of the Continental Succession were emplaced during the lower part of C26r as suggested by us, this interval could not be much longer than 0.8 m.y., but it could be slightly shorter. Furthermore, if the recovered part of the Continental Succession all erupted during the very latest phases of $\mathrm{C} 27 \mathrm{r}$, we suggested an eruption period of perhaps less than $0.5 \mathrm{~m} . \mathrm{y}$. We conclude that average eruption frequency probably was not much lower than 1 flow/11 k.y., but it could have been significantly higher, if the succession is of $\mathrm{C} 27 \mathrm{r}$ age.

To calculate the average frequency of eruption within the SDRS wedge (Site 918) the stratigraphic structure of the SDRS must be considered and an estimate of the average flow thickness must be known. A simplified stratigraphic scheme is shown in Figure 10. The Site 918 lavas have an average thickness of $\sim 6.7 \mathrm{~m}$ very similar to the average thickness $(6.5 \mathrm{~m})$ of 120 lava flows from Site 642 (SDRS at the Vøring Plateau; Eldholm, Thiede, Taylor, et al., 1987). If the main
SDRS is modeled as a series of shingled layers $6.7 \mathrm{~m}$ thick (Fig. 8), the entire SDRS wedge would comprise as many as 4500 flow units. As it formed over 3 m.y., this is equivalent to approximately 1 flow/ $670 \mathrm{yr}$. This is just over one order higher eruption frequency than the Continental Succession, but is fairly close to the eruption frequency from the Eastern Rift Zone in Iceland as recorded in historical times (Krafla Rift; approximately one eruption event every 250 yr; e.g., Björnsson, 1985; Saemundsson, 1986).

One may argue that the $6.7 \mathrm{~m}$ average thickness of SDRS flows recorded at Site 918 is not representative, as it is derived from atypical lavas that flowed far away from the rift zone, and hence, must represent the larger and less frequent events. This would imply that the true eruption frequency was higher than the one recorded within the top part of the SDRS. However, it could also be argued that the thickness of any flow would decrease with distance to eruption site, and therefore, flow thicknesses observed at the top of the SDRS wedge represent minimum values. This would imply a lower eruption frequency. It is hard to judge the relative merits of these two views in terms of their effect on the calculated eruption frequency. However, the remarkable similar thickness of Site 918 and Site 642 lavas suggests that a value of 6-7 m flow thicknesses is a reasonable average to be used for modeling. The calculated eruption frequency of 1 flow/ $670 \mathrm{yr}$ is therefore likely to be representative for large eruption events that overflowed the less than 10-km-wide rift (see Larsen and Jakobsdóttir, 1988, for width of rift) and resulted in flows traveling far away from the rift. However, the frequency of smaller eruptions within the rift must have been higher, and thus, could have been close to those observed in present-day Iceland.

In summary, the rate of eruption for the Continental Succession (minimum 1 flow/11 k.y.) is approximately one order of magnitude lower than within the main SDRS series (approximately 1 major flow/670 yr). The high eruption rate of the main SDRS series is consistent with an actively spreading system in which magma is frequently tapped during tectonic extension. Because of the strong sagging of the central rift area in the spreading system (Fig. 6), lavas for the most part are restricted to a relatively small area compared to continental flood basalts, which may spread over very large areas. Thus, the much higher eruption frequency within the SDRS in itself is consistent with magmatic fluxes estimated above, not proving a higher total volcanic productivity.

\section{Is SDRS Wedge the Result of Icelandic-Type Crustal Accretion?}

Leg 152 drilling has proven that lavas throughout the Continental and Oceanic Successions were deposited above sea level and mainly comprise lavas of basaltic composition. This confirms two of the key seismic stratigraphic interpretations from which Larsen and Jakobsdóttir (1988) concluded that the southeast Greenland SDRS formed by Iceland-type spreading as modeled by Pálmason (1986; Fig. 6).

Other observations from the drill core, albeit of more circumstantial nature, support the third of Larsen and Jakobsdóttir's (1988) interpretations in support of an Icelandic spreading origin of the SDRS, namely that the SDRS lavas had a downdip source. Thus, the marked decrease with depth of the weathering of individual lavas at Site 918 (Holmes; this volume) is also visible at Site 990 (Duncan, Larsen, Allan, et al., 1996), and suggests to us that volcanism became significantly more infrequent toward the top of these successions, and allowed for deep weathering of single flows before these were covered

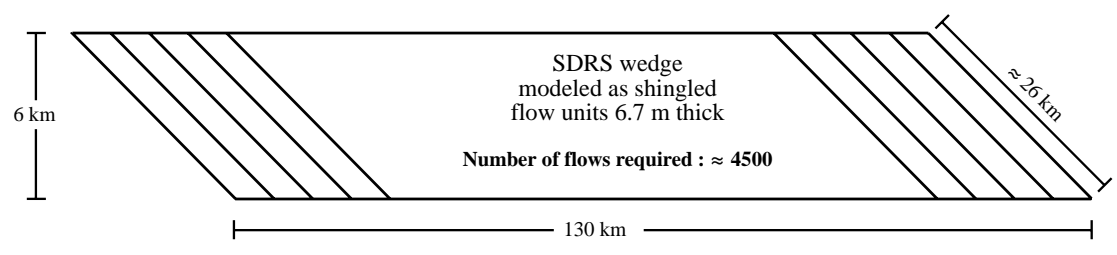

Figure 10. Schematic stratigraphy of the SDRS wedge used for calculations of eruption frequency. Because of the limited length and inclined nature of the SDRS lava flows, the required eruption frequency (at any given average thickness of flows) is higher than if a "layer cake" stratigraphic structure was present. 
by the next flow. Similarly, a change from dominantly aa flows in the top of the SDRS to dominantly pahoehoe flows deeper within the SDRS is seen at both Sites 918 and 990 (Larsen, Saunders, Clift, et al., 1994b; Duncan, Larsen, Allan, et al., 1996) and may indicate that mainly large aa flows were able to reach far away from the rift. Larsen and Jakobsdóttir (1988) further pointed out that to produce the 5$6 \mathrm{~km}$ thick southeast Greenland SDRS, spreading rates as high as those shown in Figure 9 (and a less-than-10-km-wide rift) would be necessary for a thick extrusive layer to escape later, intense dike injection within the rift zone (see also Pálmason, 1986).

One implication of the Icelandic spreading model and the observed spreading rates is that lava flows that were laid down close to the rift axis subsided (Figs. 6, 11) to a depth of around $5 \mathrm{~km}$ within approximately $0.5 \mathrm{~m} . \mathrm{y}$. This rate of subsidence $(1 \mathrm{~cm} / \mathrm{yr})$ and amount of rotation of lava beds (approximately $30^{\circ}$ at $5 \mathrm{~km}$ ) suggests effective detachment at depth, most likely below the sheeted dike zone (i.e., within the gabbroic layer 3 in Fig. 11).

The age and nature of the Continental Succession makes it less straightforward that these can be interpreted as a simple featheredge of the main SDRS wedge as originally interpreted by Larsen and Jakobsdóttir (1988) and Larsen, Saunders, Clift, et al. (1994b). By featheredge we understand lavas coherent with and forming an integral part of the main SDRS (i.e., zone of continental onlap in Fig. 6). Following this definition, we should only consider the lowermost part of the main SDRS series (Sites 915 and 990 lavas) the featheredge of the southeast Greenland SDRS (plus, possibly, the Site 917 Upper Series).

In accordance with this, a difference in structure is seen between the Continental and Oceanic Successions. According to logging data (Cambray, this volume; Le Gall and Cambray, 1996) the dip of the Continental Succession is mainly to the south and south-southwest while the Upper Series (logging data) and the main SDRS series are dipping south-southeast to southeast (logging and seismics). The latter dip directions are normal to the margin and consistent with derivation of the lavas from a margin-parallel extensional rift (spreading ridge) similar to the origin of the main SDRS series. The dip of the early volcanic sequence indicates a different setting, possibly in small continental basins forming prior to final breakup (Cambray, this volume).

\section{Transgression and Paleoelevation}

Preservation of the oldest marine record at Site 917 is several million years younger than the SDRS volcanism, and transgression seems to have followed a period of significant erosion (Larsen, Saunders, Clift, et al., 1994b; Holmes; Wei; Ali and Vandamme, all this volume). However, within the main SDRS series (i.e., Site 918) rapid transgression is indicated by the presence of syn- to late volcanic ma-

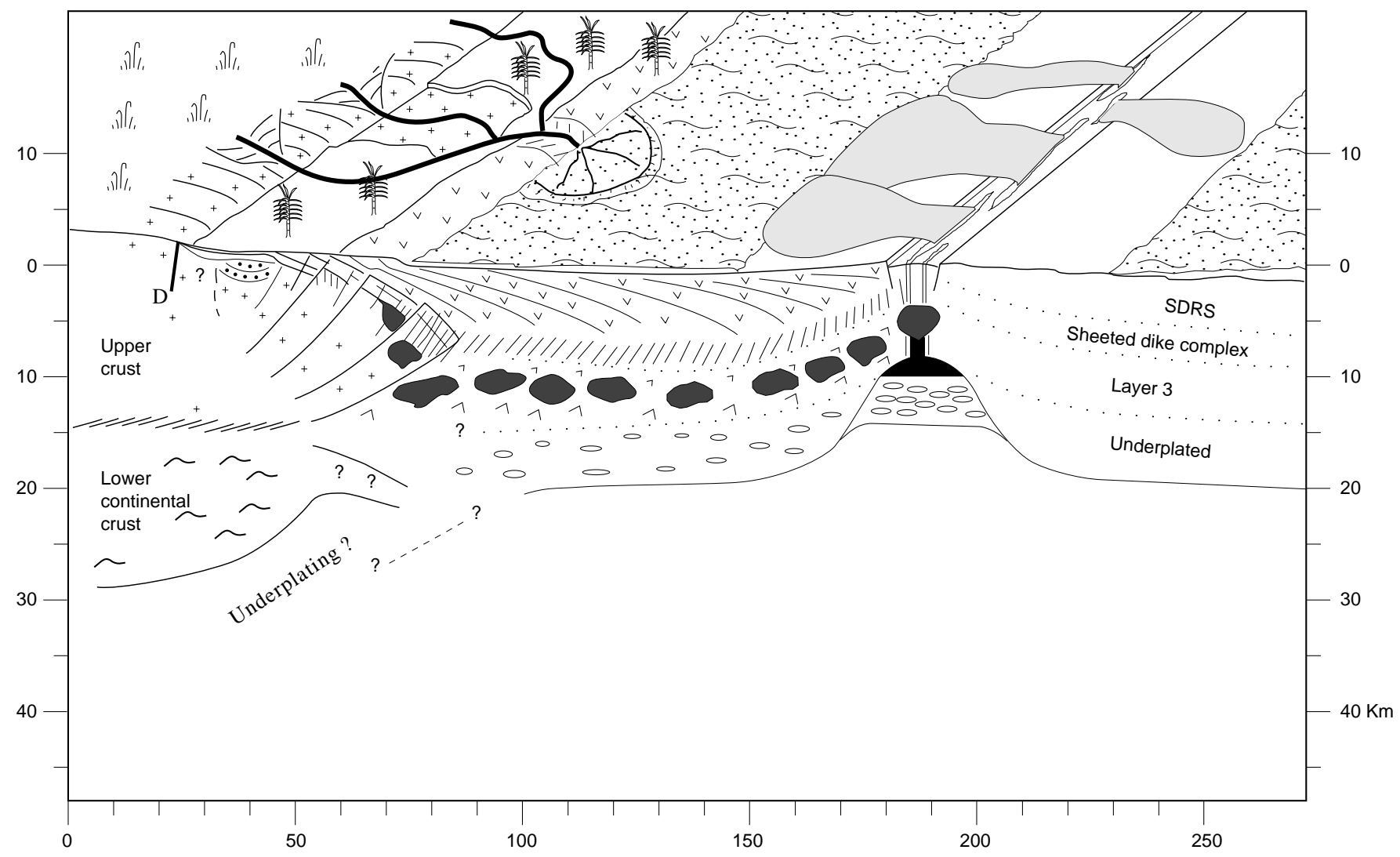

Figure 11. Schematic cross section showing formation of the main SDRS wedge at about $54 \mathrm{Ma}$. Structure of the COT from Figures 4 and 12 . The crustal thickness and layering is inferred from comparisons with other North Atlantic margins and from Larsen et al. (Chap. 39, this volume). Dense, residual Mg-rich melt is indicated to "freeze" toward the base of the more normal, gabbroic-type layer 3 and to form an underplated layer during steady-state SDRS formation. Because of this, and because of the continued additions to the upper crust by lavas flowing out of the rift zone, the crust thickens away from the rift zone until sufficiently distal from the rift to further thicken. The active spreading ridge stayed above sea level for at least $3 \mathrm{~m} . \mathrm{y}$. (56-53 Ma), but as the crust cools, a shallow sea rapidly transgresses the subsiding SDRS wedge. Deltas built out into this sea, with sediments dominated by a volcanogenic source. However, material of continental and plutonic origin are also represented. Plant fossils and pollen in the sediment show that a swamp forest covered a lowland area, but also that a higher elevation flora is represented, possibly on an uplifted rift flank. The sheeted dike complex and associated gabbro intrusions within the COT and below the SDRS are interpreted by analogies with coastal exposures and ophiolites. D = coastal dike of the same age and composition as the Site 917 Lower Series lavas. Added in proof: See also White et al. (1996), Reid et al. (1997), and Holbrook et al. (1997) for recent seismic studies of Icelandic-type crust. 
rine sediments, and erosion apparently was limited to removal of the upper part of a soil horizon (Holmes, this volume). Erosion of the igneous basement also appears to have been limited at Sites 915 and 990, but marine sediments of syn- to late volcanic age have not been identified (Duncan, Larsen, Allan, et al., 1996). This may suggest that Sites 915 and 990 subsided later than Site 918 (Clift et al., 1995; Wei, this volume). However, the syn- to late volcanic sediments at the base of Site 916 may be of the approximately same age as the Site 918 synto late volcanic sediments (Jolley, this volume). If this is true, it implies that the region around Sites 916 and 917 was not significantly elevated during breakup compared to the more seaward Site 918 (i.e., tectonic depression at Site 916 permitted early transgression), but that it first subsided regionally (and permanently) below sea level as much as perhaps $10 \mathrm{~m}$.y. later. The latter would be consistent with continental crust being present below Sites 917, 916, 915, and 990, but not below Site 918 (Larsen et al., this volume).

Independent evidence on paleoelevation is presented by Holmes (this volume), suggesting that both the Continental and the Oceanic Succession formed plateaus that were weathered in a warm humid environment at low to moderate altitudes. Based on pollen analysis Jolley (this volume) concludes that the basalt terrane was vegetated by a low-land swamp forest, but that a minor component of pollen representing a higher elevation and more temperate climate vegetation also is present in the early postrift sediments. The elevated zone may represent a (nonvolcanic?) rift flank to the west (Fig. 11).

\section{Erosion History}

Thick sediment beds of red clay at Sites 914-917 prove that during the Eocene, thick lateritic soils developed within the volcanic cover and subsequently were eroded (Larsen, Saunders, Clift, et al., 1994b; Wei, this volume; Spezzaferri, this volume) and deposited in front of deltas building into the shallow sea between the continental rift flank in the west and the emergent spreading ridge in the east (Fig. 11). Furthermore, the mineral composition of the postrift sediments varies from approximately $65 \%$ volcanic origin within the units immediately overlying the lavas, to approximately $45 \%$ volcanic origin in sediments of early Oligocene age, and the amount of quartz (i.e., continental basement lithologies) increases in the same interval from virtually absent to about $15 \%$. This suggests progressively deeper erosion of the rift flank during the Eocene and Oligocene.

However, as pointed out earlier, even the oldest postvolcanic, conglomeratic beds (early Eocene?) at Sites 915 and 990 contain clasts of continental crust, clasts from the Continental Succession, and gabbro clasts of assumed rifting origin (Larsen, Saunders, Clift, et al., 1994b; Duncan, Larsen, Allan, et al., 1996). This shows that erosion locally (river gullies, fault scarps, etc.; see Fig. 11) was deep already from early Eocene time.

The much younger glaciomarine sediments overlying the Eocene to lower Oligocene sediments at the shelf sites (914-917) show a trend similar to that seen in the Paleogene sediments with volcanic source material decreasing from approximately $35 \%$ in the oldest strata to approximately $5 \%$ in the youngest strata, and a parallel increase in quartz content from $20 \%$ to $60 \%$ (see fig. 18 in "Shelf Stratigraphic Synthesis" chapter in Larsen, Saunders, Clift, et al., 1994b). This tells us that despite the deep Paleogene erosion of the rift flank, a last (significant) part of the volcanic cover of the inner shelf (and coastal region?) in this region was not removed before glaciation during the last 7 m.y. (Larsen et al., 1994a).

\section{Paleotopography of SDRS Rift and Adjacent Volcanic Plateaus}

Leg 152 data and observations from other parts of the northeast Atlantic SDRS rift (e.g., Roberts, Schnitker, et al., 1984; Eldholm, Thiede, Taylor, et al., 1987, 1989; Saunders et al, this volume; in press) suggest that SDRS formed subaerially and close to sea level within large regions during the first few million years of spreading.
Similarly, the plateaus of continental flood basalts around the northeast Atlantic all formed mainly subaerially (Saunders et al., in press) though locally, submarine volcanic activity took place (e.g., lower part of the East Greenland flood basalts, Nielsen et al., 1981). At present, these lava plateaus are highly elevated (e.g., East Greenland) to submerged (e.g., Faeroe platform).

The East Greenland flood basalt is the largest and highest of these plateaus. A significant proportion of these lavas is known to have formed during magnetic Chron $\mathrm{C} 24 \mathrm{r}$ contemporaneous with the main SDRS series (Hansen et al., 1989; L.M. Larsen et al., 1989; Storey et al., 1996). Moreover, the internal structure of the plateau, in particular within its younger part, shows thickening of the individual formations toward the coast (i.e., toward the incipient SDRS rift). The resultant structure and lava thickness (approximately $6 \mathrm{~km}$ ) within the coastal area is not that dissimilar to the SDRS structure (Pedersen et al., 1996; Pedersen et al., 1997; Neuhoff et al., 1997) and MORBtype lavas are found interbedded with typical continental FeTi basalts (L.M. Larsen et al., 1996; Danish Lithosphere Centre [DLC], unpubl. data).

The observation that several of the formations within the East Greenland continental flood basalt thicken toward the plate boundary and comprise lavas of possible SDRS-rift origin suggests that they originally were continuous with, and at no higher elevation than, the SDRS rift. However, the plateau is presently $2-2.5 \mathrm{~km}$ high (locally as high as $3.7 \mathrm{~km}$ ). Did this plateau and adjacent SDRS rift originally form that high?

The marine nature of early volcanic products and of underlying Late Cretaceous to Paleocene marine sediments (Nielsen et al., 1981) now found at high elevations provides ample evidence for the present high elevation of the plateau to be largely the result of later margin uplift (Brooks, 1979; Larsen, 1990; Larsen and Marcussen, 1992; Christiansen et al., 1992; and Hansen, 1996). Thus, the Paleocene SDRS rift most likely was fairly close to sea level throughout the northeast Atlantic, much as the Eastern Rift Zone of Iceland is today, and significant parts of the East Greenland continental flood basalts must have formed continuously with, and at a similar elevation as, the adjacent SDRS rift.

\section{Post-Breakup Uplift and Subsidence}

The strongly increased sedimentation rates in the Oligocene within the Irminger Basin (Larsen, Saunders, Clift, et al., 1994b) seem to confirm the mid-Tertiary ages of margin uplift inferred from fission track studies for the onshore margin (Gleadow and Brooks, 1979; Hansen, 1996; Clift, 1996, this volume). However, cooling of the climate and associated acceleration of crustal exhumation of a previously uplifted terrane possibly could produce the same pattern of observations. Thus, what we confidently can conclude is that the main uplift is post volcanic and that crustal exhumation accelerated in the mid-Tertiary. A significant amount of erosion is likely to have taken place during glaciation that dates back to around $7 \mathrm{Ma}$ (Larsen et al., 1994a).

Subsidence of the featheredge of the SDRS is limited and is interpreted by Clift et al. (1995) and Clift (this volume) to reflect modest levels of crustal extension. However, significant addition of igneous material to the continental crust might have taken place during breakup (Larsen et al. (this volume), and hence, calculated crustal stretching factors may underestimate the amount of crustal stretching.

Clift et al. (1995) report the subsidence of the main SDRS wedge to fairly closely follow that of normal ocean crust (e.g., Parsons and Sclater, 1977) except that basement at Site 918 seems to have experienced some initial delay in subsidence ( $\sim-10$ m.y.). Clift et al. (1995) interpret this to reflect the passage of the plume stem below the East Greenland Margin in accordance with the Iceland plume track history proposed by Lawver and Müller (1994). However, these subsidence studies are based on shipboard estimates of paleo-depths determined (mainly) from the assemblages of benthic foraminifers (Larsen, Saunders, Clift, et al., 1994b), and shore-based studies 
Figure 12. Simplified crustal cross section from the coast along the Leg 152 drilling transect and seaward to seafloor-spreading Anomaly 23n. At this time the volcanic rift zone apparently subsided below sea level and the seaward-dipping reflector pattern is replaced by a small high and a hummocky basement surface, probably as a result of shallow-water volcanism. The profile is based on data from Larsen and Jakobsdóttir (1988), Larsen et al. (Chap. 39, this volume). Ages of magnetic chrons from Cande and Kent (1995), and locations from Figure 7. Depth scale in two-way traveltime (TWT). The upper continental crust is interpreted to thin along landward-dipping normal faults detaching at mid-crustal level (landward part) or, within the COT zone, in gabbroic material intruded at mid-crustal level.

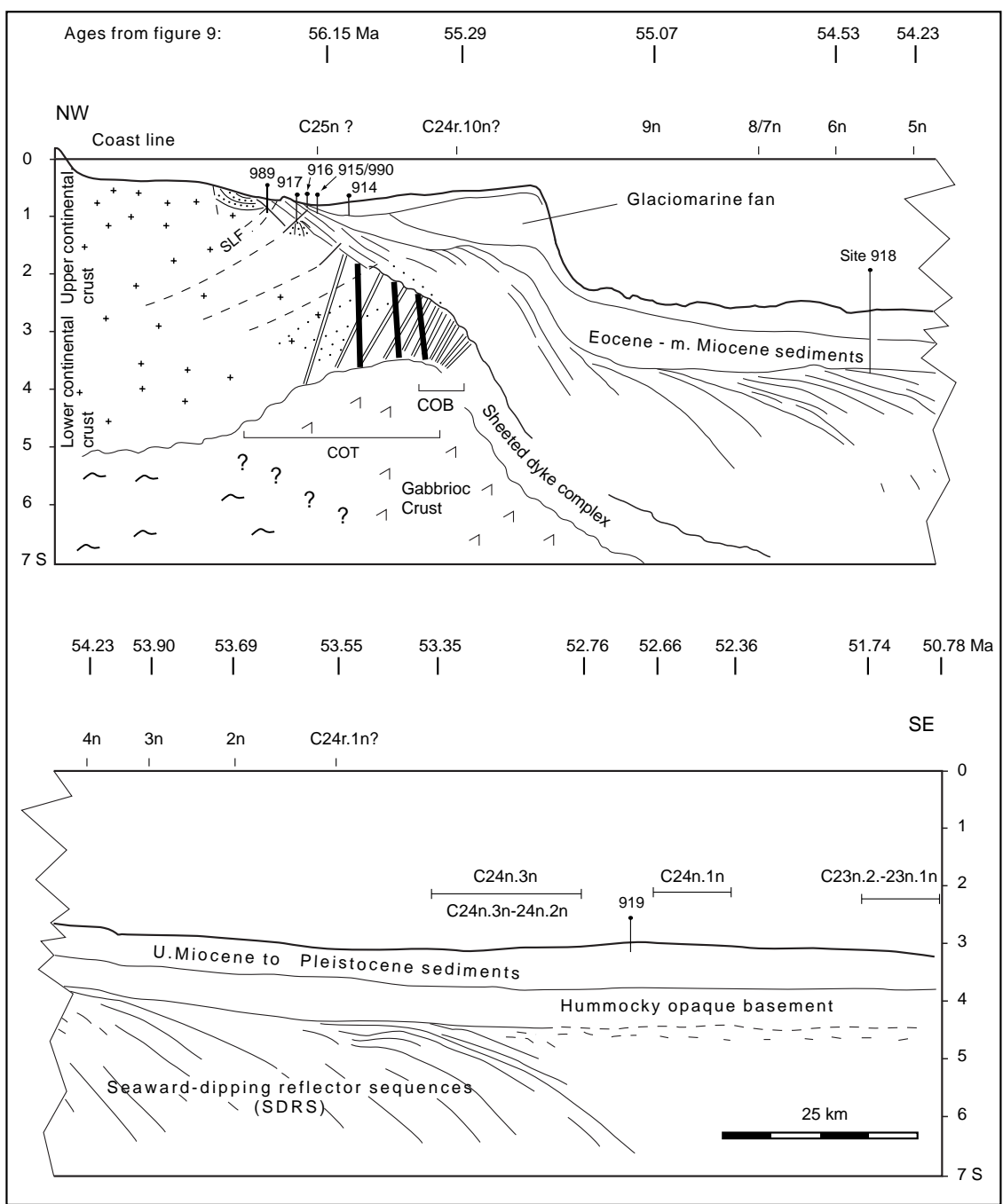

(Nemoto, unpubl. Leg 152 data) have not resulted in further corroboration of these tentative depth estimates. The subsidence curves therefore may be less precise than reported by Clift et al. (1995).

The question of the mechanism causing margin uplift is also pending. The apparent late timing of this uplift seems to exclude plume impact and associated possible underplating as plausible mechanisms. Larsen and Marcussen (1992) suggested that perhaps flexural uplift instigated by ridge push and later amplified by erosion and exhumation would be an alternative possibility.

\section{CRUSTAL STRUCTURE}

Combining information from drill cores with geophysical data allows a detailed interpretation of the COT structure (Figs. 11, 12; Larsen et al, Chap. 39, this volume). However, because some doubt regarding the exact location of the important Site 917 in relation to the deeper structures has developed since the initial Leg 152 report (Larsen, Saunders, Clift, et al., 1994b), we start with an examination of this topic.

\section{Location of Site 917 and Fault Zones Within Hole 917A}

Hole 917A penetrated the hanging wall of a landward-dipping normal fault zone into a rotated fault block (footwall) close to the intersection of the normal fault and the unconformity between pre-rift sediments and overlying rift volcanics (Figs. 4, 13). However, some navigation inaccuracy of the site-specific seismic data $(100-200 \mathrm{~m}$; identified post-cruise), the slight tilting (up to $6^{\circ}$ ) of the drill hole (Larsen, Saunders, Clift, et al., 1994b), and lack of 3D-imaging and 3D-migration of this complex structure make it uncertain where the deep part of the drill hole is located relative to the geological structure (i.e., A, B, or C in Fig. 13).

The presence of a thin fluviatile sediment at the unconformity between marine, highly inclined pre-rift sediments and the overlying lavas only seems compatible with positions $\mathrm{B}$ and $\mathrm{C}$ in Figure 13, and we therefore disregard position $\mathrm{A}$.

Total displacement across the fault zone (f-F in Fig. 13) is not known, but estimated to be at least several hundred meters and could also involve strike-slip movements (Larsen, Saunders, Clift, et al., 1994b; B. Le Gall, pers. comm., 1996). Fault trace F (Fig. 13) displays the strongest fault plane reflections and shows diffractions from the intercept of the fault trace and the breakup unconformity, suggesting major fault displacement at this location. This was the reason for selecting Site 917 during Leg 152 (in replacement of deep penetration at Site 914; Larsen, Saunders, Clift, et al., 1994b). However, Fitton et al. (Chap. 28, this volume) note that a fractured zone at approximately 570 mbsf (igneous Unit 73A) divides the Lower Series into a lower and upper part with different contamination histories, and that this may suggest some stratigraphic omission at this level. This would be consistent with hole location between $\mathrm{B}$ and $\mathrm{C}$ or at $\mathrm{B}$ with some (minor?) displacement at fault $\mathrm{f}$ (Fig. 13). The structural analysis of log- 


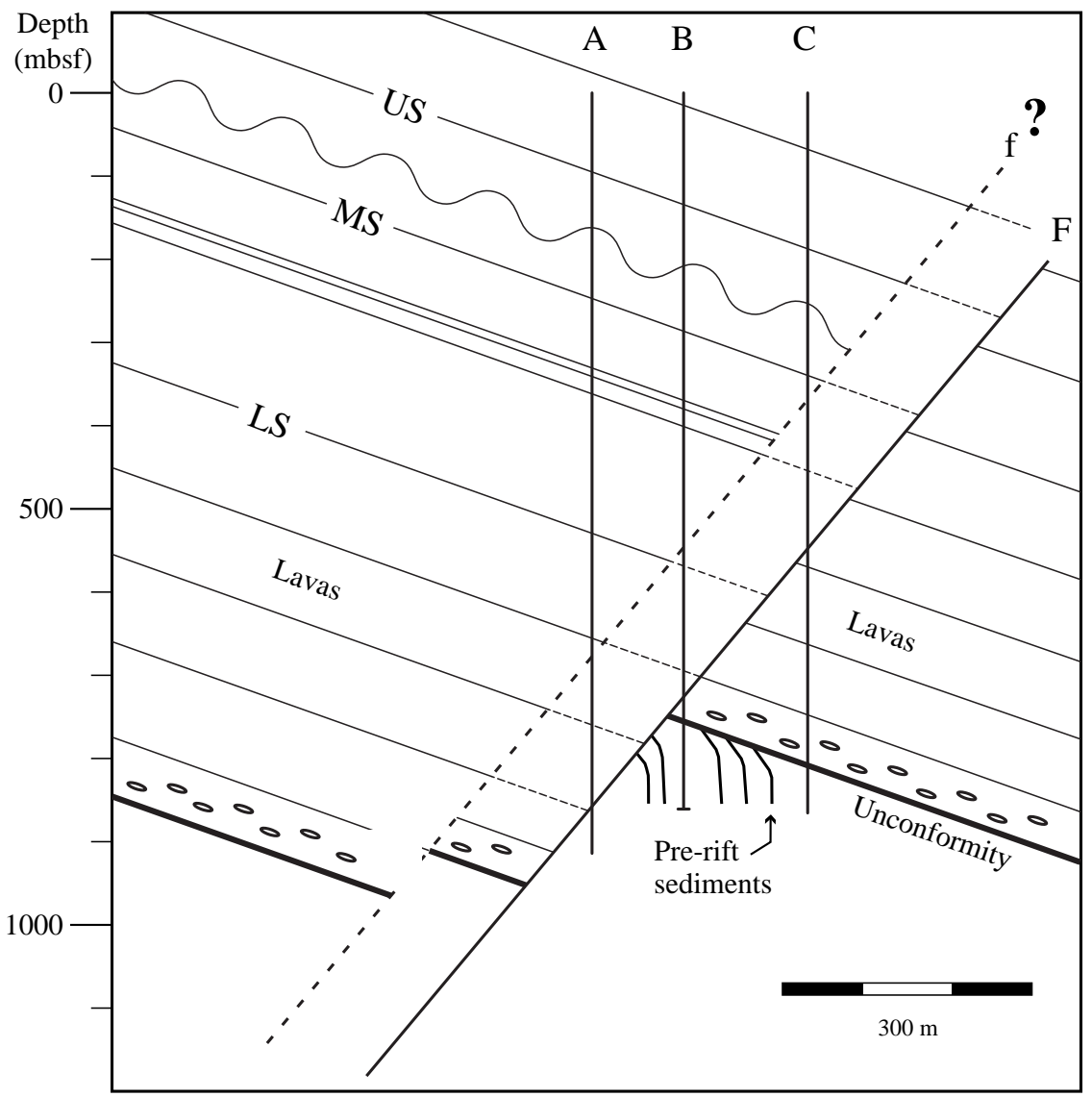

Figure 13. Schematic setting of Site 917. Detailed correlation of the drilling data to the deeper structure is ambiguous. Three different locations are shown $(\mathrm{A}-\mathrm{C}$. See main text for discussion of possible locations of Site 917 in relation to the fault-block structure. Position $\mathrm{B}$ is the preferred interpretation, and with main fault displacement along fault $\mathrm{F}$. The direction of the dip within the pre-rift sediments is an interpretation. US = Site 917 Upper Series. MS = Site 917 Middle Series. LS $=$ Site 917 Lower Series. ging data (Cambray, this volume) does not indicate significant stratigraphic omission within the Lower Series, and in several cases deformation zones are positively known to be within one flow unit (e.g., Unit 52). Likewise, a supposed pseudo-tachylite zone from within the Lower Series (Larsen, Saunders, Clift, et al., 1994b) has been examined post-cruise and found to consist largely of a metamorphic prehnite-(pumpellyite) assemblage (D. Curewitz and J. Karson, pers. comm., 1997). Below 785 mbsf (not logged), that is, close to the base (820.7 mbsf) of the Lower Series in Hole 917A, the drill core shows intense fracturing and frequent slickensides suggesting proximity to the main fault, which seems difficult to reconcile with location $\mathrm{C}$ in Figure 13.

In summary, there is no unique interpretation of the exact location of the drill site, or of the amount, and distribution, of fault displacement. The most likely position of the drill hole is position B in Figure 13 , and with main fault displacement at $\mathrm{F}$, possibly with associated (minor) fault displacement at $\mathrm{f}$ and/or between $\mathrm{F}$ and $\mathrm{f}$. Stratigraphic omission is likely to be in the order of a few hundred meters, and concentrated toward the bottom (or below) the drilled volcanic section. Thus, the record of a potentially different, initial phase of volcanism could have been lost. Leg 163 tried, unsuccessfully, to resolve this question (Duncan, Larsen, Allan, et al., 1996) by drilling at Site 989 (Figs. 4, 12).

\section{Pre-Rift Sediments}

Site 917 penetrated $779.5 \mathrm{~m}$ of mainly basaltic lavas, a normal fault zone and bottomed in a seaward rotated fault block (Figs. 4, 12, 13). The first diagnostic footwall feature in Hole 917A is a thin (14 $\mathrm{cm}$ recovered), fluviatile quartzose synrift sediment at the unconformity between the Lower Series lavas and steeply to subvertically dipping metamorphosed pre-rift sediments (Fig. 13; Vallier et al., this volume). Larsen, Saunders, Clift, et al. (1994b) referred to this unconformity as the "tectonic" breakup unconformity, and suggested that significant block faulting and crustal thinning took place shortly before formation of the unconformity. As discussed below, this interpretation probably needs modification.

\section{Origin and Setting}

The pre-rift sediments were sampled over an interval approximately $50 \mathrm{~m}$ below the basal unconformity, but because of their steep dip only a few meters of stratigraphic coverage were accomplished.

Downcore the dip of the sediment bedding rapidly changes from $30^{\circ}$ to $40^{\circ}$ just below the unconformity through locally subvertical to around $70^{\circ}-75^{\circ}$ within the lower half of the drilled section. The drilled sediment section consists of thin-bedded claystone, siltstone, and subordinate sandstone and is interpreted as relatively distal turbidites deposited in a moderately deep marine basin (deep shelf; Larsen, Saunders, Clift, et al., 1994b; Vallier et al., this volume). The amount of organic carbon is relatively high (up to $4 \%$ ). Based on the chemical composition of the sediment, Vallier et al. (this volume) suggest that a significant volcanogenic (mafic) component is present within the sediment. However, no primary minerals of magmatic origin have been identified with confidence, but abundant chlorite (Vallier et al., this volume) is interpreted as replacement of primary magmatic minerals during greenschist metamorphism. Because of the metamorphism, no biostratigraphic age determinations have been possible (Jolley, this volume).

\section{Metamorphism}

Despite their metamorphic grade and steep dip the pre-rift sediments show no schistocity or other evidence for a penetrative strain. 
Figure 14. Outcrop (approximately north-south) at the northeastern slope of the Gabbrofjeld (Kangerlussuaq region) of the Ryberg Formation (clinoformal beds dipping to right, i.e., north) overlain by the breakup unconformity (white band; Shjelderup Member, SHJ). The insert shows a detail of the breakup unconformity exposed on the back side of Gabbrofjeld (mirror imaged to conform with the main figure). The overlying lavas (and the Shjelderup Member) belong to the Vandfaldsdalen Formation (VFF; see also text and Fig. 15). Note that the sediments at the bottom of the outcrop are approximate concordant with the lavas of the Vandfaldsdalen Formation. This shows that most of the apparent unconformity at the breakup unconformity is of depositional origin (topsets of the clinoformal beds). However, an unconformity of a few degrees actually is present, and minor normal faulting affected the breakup unconformity (M. Larsen and D. Curewitz, pers. comm., 1996). Interpreted correlation to the Site 917 stratigraphy shown to the left. Lavas are dipping slightly southward (i.e., opposite to the Ryberg Formation). The steep dip of the pre-rift sediments at Site 917 suggests that the tectonic rotation of the Lower Series lavas was in the approximately same direction as the initial dip direction of the pre-rift sediments. F = normal fault displacing the unconformity and overlying Vandfaldsdalen Formation. Photo by T.D.F. Nielsen, Danish Lithosphere Centre.

The greenschist metamorphism is interpreted to reflect low pressure conditions (Larsen, Saunders, Clift, et al., 1994b; Vallier et al., this volume).

Greenschist facies metamorphism of pre-rift sediments and overlying lavas is also seen in coastal exposures, typically within the coastal dike swarm and adjacent to large Tertiary intrusive rock bodies (e.g., Nielsen et al., 1981; Bird et al., 1985, 1988; Myers et al., 1993). Vallier et al. (this volume) therefore relate the metamorphism at Site 917 to possible magma chambers, sills, and dikes adjacent to the metasediments. However, according to Demant (this volume), the overlying lavas show a lower metamorphic facies (zeolite facies), and both Demant (this volume) and Vallier et al. (this volume) discuss the possibility of a prevolcanic greenschist metamorphism of the sediments.

However, the prehnite-(pumpellyite) assemblage identified within the Lower Series lavas within a metamorphic vein or faulted zone (reported as pseudotachylite by Larsen, Saunders, Clift, et al., 1994b; see above) suggests that at least locally within the basaltic cover, the metamorphic grade has been higher than interpreted by Demant (this volume). Furthermore, the greenschist grade of the pre-rift sediments is observed in the footwall of the fault zone, and the zeolite metamorphism in the hanging wall. Late- to postmetamorphic offsets across the fault (strike-slip as well as normal), in particular if contact-type metamorphism occurred, could significantly affect the present distribution of metamorphic facies.

\section{Cretaceous-Paleocene Basins Along the Southeast Greenland Margin}

Larsen (1980) suggested that the scarce occurrences of prebasaltic, shallow marine to littoral sediments along the coast south of Kangerlussuaq Fiord (Wager, 1934) could represent the western (landward) margin of Late Cretaceous to early Tertiary basin(s) that later became the locus of final breakup. However, subsequent seismic investigations (e.g., Larsen, 1990) showed no record of such basins below the inner, basement-dominated shelf south of the Denmark Strait (Fig. 3) and showed the middle and outer shelf to be covered by thick rift volcanics and postrift sediments. However, the notion of a coast-parallel pre-rift basin off southeast Greenland was included in Ziegler's (1982) paleogeographic maps. The finding at Site 917 of fairly deep marine pre-rift sediments is the first firm evidence in sup- port of such a basin. In light of the Site 917 findings, shallow seismic data are interpreted to show the presence of a sequence, several hundred meters thick, of prevolcanic sediments just landward of Site 917 and partly below Site 989 (Fig. 12). This, and the marine facies of the Site 917 pre-rift sediments, indicate that the pre-rift basin in this position was considerably deeper and thicker than the coastal exposures indicate, and perhaps similar to the Kangerlussuaq basin farther north (see below).

The age of the Site 917 pre-volcanic sediments remains undetermined. The oldest overlying lavas are approximately $61 \mathrm{Ma}$ (midPaleocene; Berggren et al., 1995). Thus, the youngest pre-rift sediments at Site 917 must be of early Paleocene or older age. Based on regional considerations Vallier et al (this volume) suggested a Cretaceous age for the Site 917 pre-rift sediments. The uplift of the pre-rift sediments and the deposition of the fluviatile sediment at the base of the overlying lavas is related to the initial magmatism (Larsen, Saunders, Clift, et al., 1994b) and most likely took place just prior to 61 $\mathrm{Ma}$ (i.e., during the early to mid-Paleocene).

\section{Possible Correlation of Pre-Rift Sediments with the Kangerlussuaq Basin}

A sequence of marine pre-rift sediments, an unconformity marked by a fluviatile quartzose sediment and overlying basaltic lavas is widespread in the Kangerlussuaq area (Brooks and Nielsen, 1982) and similar to that recovered at Site 917 except that the breakup unconformity seems to be stronger at Site 917 (Fig. 14).

The approximately $800 \mathrm{~m}$ Kangerlussuaq Basin (see M. Larsen et al, 1996, for recent review) started to subside in the late Early Cretaceous with shallow marine sediments transgressing the Precambrian basement (Fig. 15). The basin deepened and became wider during the mid- to Late Cretaceous and shows evidence of significant shallowing during latest Cretaceous to early Paleocene time.

The younger part of the Kangerlussuaq Basin, the Late Cretaceous (Campanian?) to early Paleocene and approximately $200-\mathrm{m}$ thick Ryberg Formation, consists of submarine fan sediments showing progressive shallowing and eventually (limited) erosion and deposition of a fluviatile, in part quartzitic, unconformable conglomerate (Figs. 14, 15). The Ryberg Formation was sourced from the (present) inland area and toward the (present) coast and shelf area. (M. Larsen et al., 1996; M. Larsen, 1996). The unconformable conglomerate on 


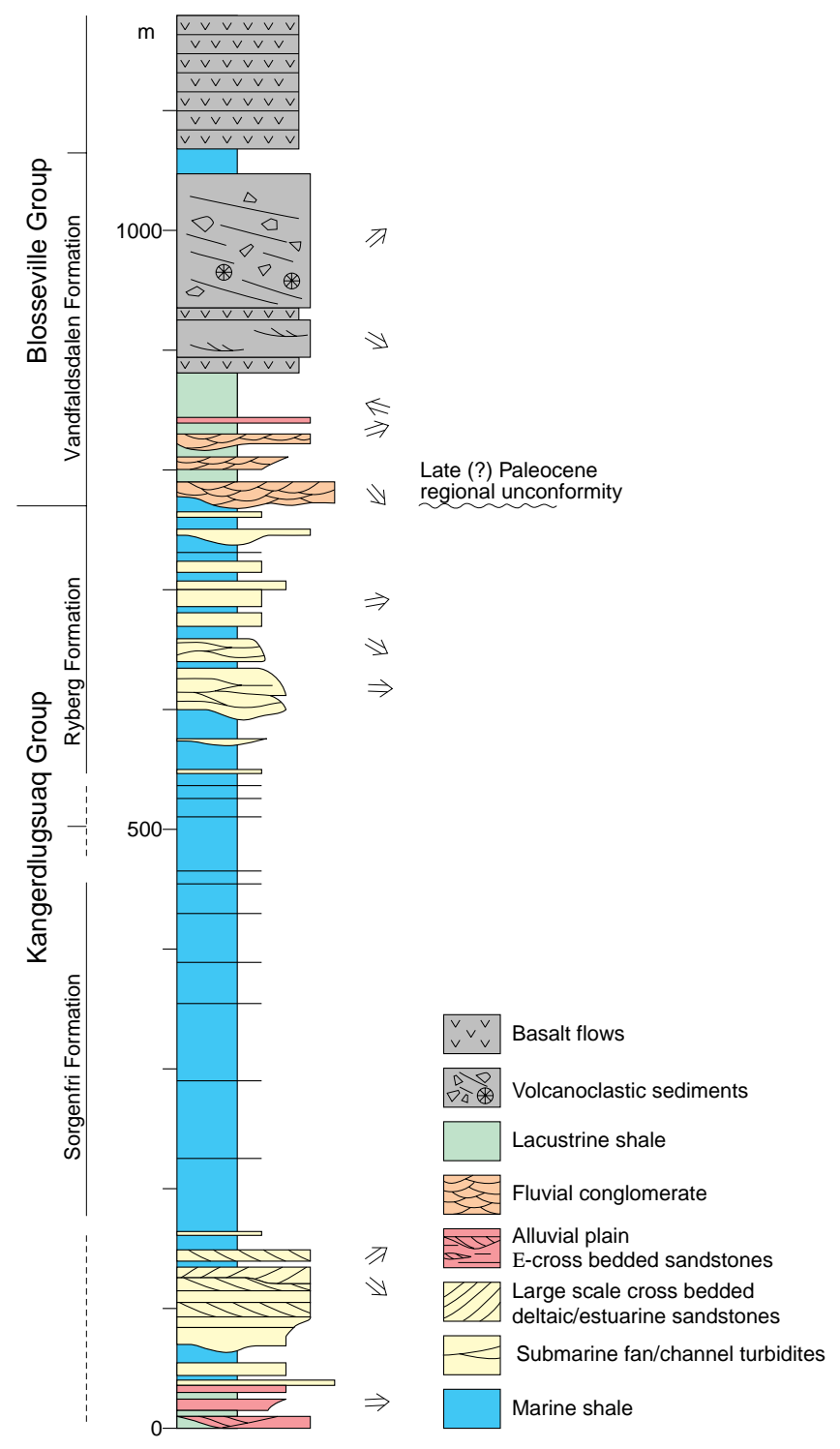

Figure 15. Stratigraphy of the Kangerlussuaq Basin. The sedimentary development reflects an initial mid-Cretaceous transgression and deepening followed by an overall shallowing during the Late Cretaceous-early Paleocene (Ryberg Formation). Paleocene uplift caused regional erosion and a change from marine to continental deposition (Vandfaldsdalen Formation with the initial Shjelderup Member). The succession is overlain by lava flows of the Vandfaldsdalen Formation interbedded with volcanogenic sediments marking the onset of volcanism in the region. Modified from M. Larsen et al. (1996).

top of the Ryberg Formation defines the bottom (Shjelderup Member) of the overlying Vandfaldsdalen Formation. This up to 600-mthick formation comprises lavas (in part pillow lavas; basalts and more evolved magmas), tuffs, and sediments of assumed late Paleocene to perhaps earliest Eocene age (magnetic Chron C24r according to Soper et al., 1976a, 1976b, and Nielsen et al., 1981; Tarling et al., 1988). However, its limited dinoflagellate cyst assemblage does not rule out that it could be older (D. Jolley, pers. comm.; 1996; Saunders et al., this volume). Recent age determinations of initial volcanism in the Kangerlussuaq region in fact suggest a mid-Paleocene age (Storey et al., 1996) consistent with magnetic Chron C26r and the age of early volcanism on the conjugate Faeroe platform (Waagstein and Hald, 1984; Waagstein, 1988).

Thus, the general lithologic and tectonic correlation between the sequence drilled at Site 917 and the Kangerlussuaq Basin (Fig. 14) is consistent with all available data, but is lacking critical age control. However, regardless of this uncertainty, a drill core from the Kangerlussuaq section in Figure 14 would suggest the presence of a marked angular unconformity (Shjelderup Member), although only a modest angular unconformity is present, and most of the dip within the underlying Ryberg section is of depositional origin. Steepening of bedding downcore below the quartzitic sediment layer in Hole 917A could therefore be interpreted as a transition from top-lap of "Ryberg Formation-type" sediments to steeper clinoformal beds (Fig. 14). The tectonic breakup unconformity (and hiatus) at Site 917 could therefore be significantly more subtle than previously interpreted (Larsen, Saunders, Clift, et al., 1994b; Larsen et al., this volume), in particular if the Lower Series lavas are dipping more steeply (Cambray, this volume) than originally thought.

In summary, one might simply view the drilled section at Site 917 as a more developed (in terms of tectonism and metamorphism) transition from rift basin to breakup volcanism (i.e., closer to the COT) than the transition exposed in the onshore Kangerlussuaq Basin (Fig. 14). This interpretation is consistent with increasing metamorphism and (rapidly) increasing dip toward the coast (i.e., toward the COT) of the lava cover in the Kangerlussuaq Basin where, eventually, the rift unconformity is disappearing below sea level (Nielsen and Brooks, 1981). Also, the few exposures of thin pre-rift sediments and rift lavas along the coast south of Kangerlussuaq show considerable seaward dip and metamorphism $\left(45^{\circ}\right.$, locally subvertical; Wager, 1934; Myers, 1980; Myers et al., 1993; C. Tegner, pers. comm., 1996).

\section{Regional Correlation of the Site 917 Tectonic Breakup Unconformity}

Basin uplift related to initial, early Tertiary North Atlantic magmatism at the southeast Greenland Margin (Sites 917 and Kangerlussuaq Basin) provides a critical link between the northwest European margin and the Labrador-West Greenland Margin where similar developments have been documented (e.g., England et al., 1993).

Around the boundary between the Lower and Upper Paleocene (Danian/Selandian boundary, $61 \mathrm{Ma}$; Berggren et al., 1995), a number of basins within the northern North Sea and the Faeroe-Shetland channel record uplift of source areas and of the shallow, marginal parts of the basins while the deeper parts of the basin subsided without any clear evidence for tectonic extension (e.g., Turner and Scrutton, 1993). Based on facies developments (e.g., Maureen Formation), trace-minerals (Knox and Morton, 1988) and correlation with published ages for the British Tertiary volcanism and the Faeroes (Mussett, 1986; Mussett et al., 1988; Waagstein, 1988; Pearson et al., 1996) this regional basin inversion has been interpreted as reflecting uplift in conjunction with initial North Atlantic Tertiary Igneous Province (NAIP) activity at approximately $61 \mathrm{Ma}$ (Galloway et al., 1993; Den Hartog Jarger et al., 1993; O’Connor and Walker, 1993; Morton et al., 1993).

Initiation of spreading in the northern Labrador Sea (including local SDRS development) also took place about C27n to early C26r time (Chalmers et al., 1993), and the West Greenland flood basalts also extruded during this time (approximately 61-60 Ma; Storey et al., 1996). Basin uplift prior to the West Greenland volcanism is reported by Henderson et al. (1976), Balkwill (1987), Pedersen and Pulvertaft (1992), and Dam and Sønderholm (in press).

In summary, there is regional evidence for basin uplift associating the initial, early Tertiary North Atlantic volcanism. The age of the basal unconformity at Site 917 is naturally related to the age of the overlying lavas (Fig. 14) and therefore must be of approximately 61 
Ma, and hence, part of the regional, mid-Paleocene North Atlantic uplift and unconformity. The very similar unconformity in the Kangerlussuaq Basin is most likely of the same age.

\section{Volcanic Stratigraphy and the Deep Structure of the COT}

The crustal model presented by Larsen et al. (Chap. 39, this volume) comprises a 40-km-wide COT below the mid- to outer shelf (Figs. 11, 12). Thinning of the continental crust is concentrated between Site 917 and $25 \mathrm{~km}$ seaward, and is interpreted to have taken place along landward-dipping normal fault zones like the fault zone drilled at Sites 916 and 917 (Figs. 4, 12). Deep reflection seismic data indicate that landward-dipping faults continue to mid-crustal depths. Landward-dipping faults with considerable development of pseudotachylite are also reported from the coastal flexure and dike zone (Karson et al, 1994; 1996). Thus, in our interpretation, the faulted and seaward-flexed zone around Site 917 is correlated with the coastal flexure (location in Fig. 3). Rotation of fault blocks and, in particular, crustal dilation due to dike injection most likely becomes more significant seaward of Site 917.

The transition from the Continental to the Oceanic Succession is documented by a number of studies (Larsen, Saunders, Clift, et al., 1994b; Fitton et al., Chaps. 28 and 29, this volume; Fram et al., this volume; Thy et al.; this volume) to mark profound changes in melting regime and magma conduits. These studies suggest that the final collapse and removal of the continental lithosphere took place just prior to and during the formation of Site 917 Upper Series, and that the lavas at Sites 915 and 990 represent Icelandic-type crustal accretion (see also review and discussions in Saunders et al., this volume).

Interpretation of the main SDRS wedge as representing Icelandic crust implies a maximum lava flow distance from a downdip source of approximately $25 \mathrm{~km}$ (Pálmason, 1986; Larsen and Jakobsdóttir, 1988). Thus, from the vertical record of changes in magmatism from Site 917 to Sites 915 and 990 (i.e., COT in a lava stratigraphic sense), we can estimate that the active rift (i.e., COT in crustal sense) was located a maximum of $25 \mathrm{~km}$ downdip of the latter drill sites (Fig. 12). This is in agreement with the interpretation of geophysical data by Larsen et al. (Chap. 39, this volume).

It is not possible to precisely ascertain the amount of faulting and crustal thinning prior to the initial volcanism (Continental Succession). Originally, the steep dip of the pre-rift sediments below the Lower Series lavas at Site 917 was interpreted as evidence of considerable crustal thinning prior to volcanism (Larsen, Saunders, Clift, et al., 1994b). However, as discussed above, a significant part of the dip of the pre-rift sediments may be of depositional origin. Furthermore, the dip of the lowermost lavas may be higher than originally estimated (Cambray, this volume). Thus, tectonic rotation and crustal thinning prior to volcanism seem significantly overestimated by Larsen, Saunders, Clift, et al. (1994b). In fact, Larsen and Marcussen (1992) showed that the Jameson Land basin partly underlying the Scoresby Sund lavas (location in Fig. 3), despite acting as a magma conduit, did not suffer any crustal thinning in relation to the magmatism. Similarly, the Kangerlussuaq Basin only shows limited tectonic rotation and stretching (M. Larsen, 1996; J. Karson and D. Curewitz, pers. comm., 1996). Indeed, also the regional coastal flexure zone (including the SDRS featheredge) suggests that considerable crustal thinning is following, rather than preceding, initial magmatism. This is because all along this zone, the earliest volcanic products and the associated magma chambers (gabbros) are tilted seaward, with the oldest lithologies showing the steepest dip (e.g., Nielsen and Brooks, 1981; Myers et al., 1993; Larsen, Saunders, Clift, et al., 1994b; Karson et al, 1996; C. Tegner, unpubl. data; Cambray, this volume).

The compositional development of the Continental Succession at Site 917 is consistent with limited crustal (and lithospheric) thinning prior to volcanism. As reviewed above (see also Saunders et al., this volume) melting took place below a continental lithospheric lid, and lavas erupted from crustal magma chambers. Continental contamination rapidly decreases upward within the Site 917 Upper Series. This is consistent with the presence of a relatively intact continental crust (Larsen et al., Chap. 39, this volume; T. Dahl-Jensen, unpubl. DLC data) in which magma chambers could form at crustal scale density traps (e.g., Quick et al., 1994, 1995).

Finally, the profound lithospheric thinning (i.e., removal of the lithospheric lid) recorded by Site 917 Upper Series lavas is paralleled by a marked decrease in continental contamination (Fram et al., this volume; Fitton et al., Chap. 29, this volume) suggesting that during this time the continental crust was highly attenuated as well. However, a low level of crustal contamination persists within the younger lavas at Site 915 (and Site 990; G. Fitton, pers. comm., 1996) and suggests that the parental magma of these lavas maintained some contact with continental crust. This is consistent with the hypothesis that detached panels of continental (lower) crust could be present at depth within this oldest, Icelandic-type igneous (SDRS) crust (figs. 7, 8 in Larsen et al., Chap. 39, this volume).

\section{EMPLACEMENT OF ANOMALOUS MANTLE AND MELT EXTRACTION}

Already prior to Leg 152 it was generally accepted that a layer of mantle different from normal mid-ocean-ridge asthenosphere must have existed during early Tertiary breakup in order to explain the excessive magmatism along the northeast Atlantic rifted margins (see summary in Larsen, Saunders, Clift, et al., 1994b; Duncan, Larsen, Allan, et al., 1996; Saunders et al., in press; this volume; White, 1997). Only one hypothesis involving forced mantle convection during breakup (Mutter et al., 1988) suggests that this excessive volcanism could be derived from normal asthenospheric mantle. We later discuss this possibility, but for the moment focus on models involving the (transient) presence of an anomalous sublithospheric mantle able to yield the high magmatic fluxes present during breakup.

\section{Models of Anomalous Mantle Formation}

Hypotheses of anomalous melt-yield mantle (AMYM) conveniently can be grouped into two types: (1) rapidly emplaced, anomalous mantle; or (2) a slowly developing mantle anomaly. Type 1 AMYM is exclusively related to mantle plumes rising from depth (670 km discontinuity or lower mantle/core-mantle boundary. Type 2 AMYM can involve long-standing plumes (e.g., Lawver and Müller, 1994), incubating plumes (e.g., White and McKenzie, 1989; Kent et al., 1992) or a long-term buildup of a temperature anomaly below the continental lithosphere (Anderson et al., 1992). These different models are normally discussed under the assumption of dry mantle conditions with mantle temperature as the main variable. Estimates of the required temperature anomaly vary for both categories from approximately $100^{\circ}$ to $300^{\circ} \mathrm{C}$ above normal asthenospheric temperature (e.g., Schilling, 1991; Ribe et al., 1995; White et al., 1995).

Results from Leg 152 drilling, mainly the occurrences of picrites, suggest that hotter than normal temperature mantle was present during breakup (see Saunders et al., this volume, for summary), and this is further corroborated by the high magmatic fluxes we have calculated in the present study. Thy et al. (this volume) estimated the excess temperature to approximately $100^{\circ} \mathrm{C}$, and suggested that, possibly, a slightly damp mantle initially was present.

In the context of continental breakup, the main difference between the two categories of models is whether breakup is caused by the rapid emplacement of anomalously hot mantle below a continent that consequently parts, or alternatively, breakup is caused by other forces releasing (through decompression) excessive volcanism from a long-standing mantle anomaly. 


\section{Rapid or Slow Emplacement of Anomalous Mantle?}

One of the most significant and surprising results of Leg 152 drilling is the discovery of the approximately $61 \mathrm{~m} . y$. old Continental Succession predating final breakup and the more voluminous, higher magmatic flux main SDRS series with 3-4 m.y. This age complies well with initial North Atlantic volcanism starting almost synchronous at around 61-62 Ma (Storey et al., 1996; review in Saunders et al., this volume). In particular the extremely close, if not coincident, timing of initial volcanism in West Greenland and southeast Greenland (this paper; Storey et al., 1996) is striking and may, as discussed later, suggest extremely fast emplacement of AMYM.

However, one could also argue that, if volcanism in a region as large as the NAIP virtually was initiated at the same time, then anomalous mantle already was widely distributed below the region well before 61-62 Ma and that the remarkable coincident initiation of magmatism was caused by simultaneous rifting across the region. Before discussing this interpretation we note that: (1) Larsen and Jakobsdóttir (1988) demonstrated a clear link along the Iceland hot spot track (Denmark Strait) between the anomalous margin structure (SDRS crust) and Iceland, and drilling results (i.e., emplacement environment, mantle source, magmatic flux) support this interpretation; (2) considerable evidence for a deep-seated source of the Iceland anomaly exists and recently has been imaged by seismic tomography (Wolfe et al., 1997); (3) Late Cretaceous development of a nonvolcanic margin structure off southwest Greenland (Chian et al., 1995); (4) a number of rift basins within the northeast Atlantic show considerable rifting and deepening during the Cretaceous (Skogseid et al., 1992), but none display any significant volcanism before breakup; and (5) sudden basin inversion (uplift) associated the initiation of volcanism at 61-62 Ma in a large region from West Greenland to southeast Greenland.

In our view these regional constraints exclude non-plume models by Anderson et al. (1992) and Mutter et al. (1988) to work independently of the Iceland plume and firmly tie the 61-62 Ma North Atlantic AMYM to the arrival of the Iceland hot spot (see also Saunders et al., this volume). However, is it possible, as proposed by Lawver and Müller (1994), that the Iceland plume stem previously has fed and maintained a large plume head over which the North Atlantic lithosphere drifted during the Late Cretaceous and early Tertiary? Or in other words, that the plume head did not impact from below, but slowly moved laterally under the NAIP?

To maintain for long periods of time a plume head large enough to explain formation of the NAIP the flux through the plume stem would have to be high enough to compensate for both plume discharge through its proposed history (Siberian Traps, Alpha Ridge in the Canada Basin, and Canadian Arctic archipelago; see Lawver and Müller, 1994) and for the cooling of the plume head (Sleep, 1996). Following discharge events the plume head then would have had to re-incubate and its axis (stem) to drift from northwest across the Baffin Bay area and below central Greenland along a track just north of the West Greenland flood basalt province (Figs. 1, 2). This in fact makes this model very similar to an incubating plume model (for discussion of possible rates of incubation, see later section in this paper). However, it is most difficult to see how a slowly approaching and, at the same time, incubating plume head could be consistent with the observed tight coincidence in time of both initial magmatism and basin inversion across the approximately $2000-\mathrm{km}$-wide NAIP. Thus, if the coincidence in magmatism were to be explained by simultaneous change of the stress field to regional extension (as implied by the Lawver and Müller model), the basin inversion is left unexplained. Also, as pointed out earlier, the considerable, nonvolcanic basin extension in the North Atlantic region that took place during the Cretaceous (including the West Greenland Margin proximal to the approaching plume) is indicative of normal asthenospheric mantle being present prior to the Tertiary.
In the following, we therefore pursue models of ultra-fast emplacement of anomalous mantle below the North Atlantic lithosphere around 61-62 Ma.

\section{Ultra-Fast Emplacement of a Low-Viscosity Hot Mantle?}

In the rapidly impacting plume model, the spatial distribution of initial magmatism as a function of time ought to reflect the location of the impact site and the velocity of mantle flow laterally away from the impact area. In the following we estimate how rapidly the anomalous mantle would have had to spread below the lithosphere to satisfy present constraints on the age of initial NAIP activity.

Within the resolution of current geochronological data on initial magmatism we see no systematic geographical trend from west to east across the NAIP (Storey et al., 1996; M. Storey, pers. comm., 1997; for summary of NAIP ages, see Saunders et al., this volume).

The apparent coincidence in time of initial magmatism from west to east across the NAIP could be explained by either very rapid lateral flow, or with an impact geometry in which the plume impact center was located at approximately the same distance from the three observation points (i.e., West Greenland, southeast Greenland, and British Province). The latter would imply an impact site around the East Greenland flood basalts (entrance of Scoresby Sund fiord in Fig. 2). However, this position would suggest that the earliest (and strongest?) NAIP activity was to be found in these northern parts of the NAIP. This is not supported by current data.

The plume track model by Lawver and Müller (1994) shows that the plume stem at 61-62 Ma was closer to West Greenland than to southeast Greenland and to the British province (Figs. 1, 2). If we assume the diameter of the impacting plume head (see later discussion) was $500 \mathrm{~km}$ before impacting and spreading laterally below the lithosphere, plume material would have had to travel an additional distance of approximately 500 to $1000 \mathrm{~km}$ to reach southeast Greenland, the British Isles, and West Greenland within a time interval below current resolution of age data. For calculation of the approximate lateral spreading velocity we assume that the plume front traveled 500 $\mathrm{km}$ in less than $1 \mathrm{~m} . \mathrm{y}$. This results in a horizontal velocity of plume material of $0.5 \mathrm{~m} / \mathrm{yr}$.

Ultra-fast ascent rate (1-10 m/yr) and rapid lateral flow of plume head material have been modeled by Yuen and Larsen (1996), T.B. Larsen et al. (1996), and T.B. Larsen and Yuen (1997) by applying non-Newtonian (i.e., nonlinear) mantle rheology. Sleep (1996) further modeled the lateral flow of a low viscosity $\left(0.4 \times 10^{18} \mathrm{~Pa} \mathrm{~s}\right)$, hot mantle following plume emplacement of this below the lithosphere. Both these model studies suggest that lateral flow of hot mantle material transiently can be as high as approximately $0.5 \mathrm{~m} / \mathrm{yr}$. In the following we refer to such rapid emplacement and lateral spread of plume material as "plume surge."

\section{Preferred Model}

According to present geochronological constraints the hypothesis of plume surge during initial plume impact implies an impact time of just prior to 61-62 Ma. We now discuss the consistency of a plume surge model (Fig. 16) with constraints on magma sources, temporal development in magmatism, required volumes of plume material and the magmatic flux during breakup, and how the present-day Iceland plume structure may differ from the structure during impact structure.

\section{Mantle Sources}

In the surging plume model, the plume head spreads laterally very quickly along the base of the lithosphere into a thin sheet with a diameter several times the original plume head diameter (T.B. Larsen et al., 1996). This sheet is not significantly thicker than the plume 


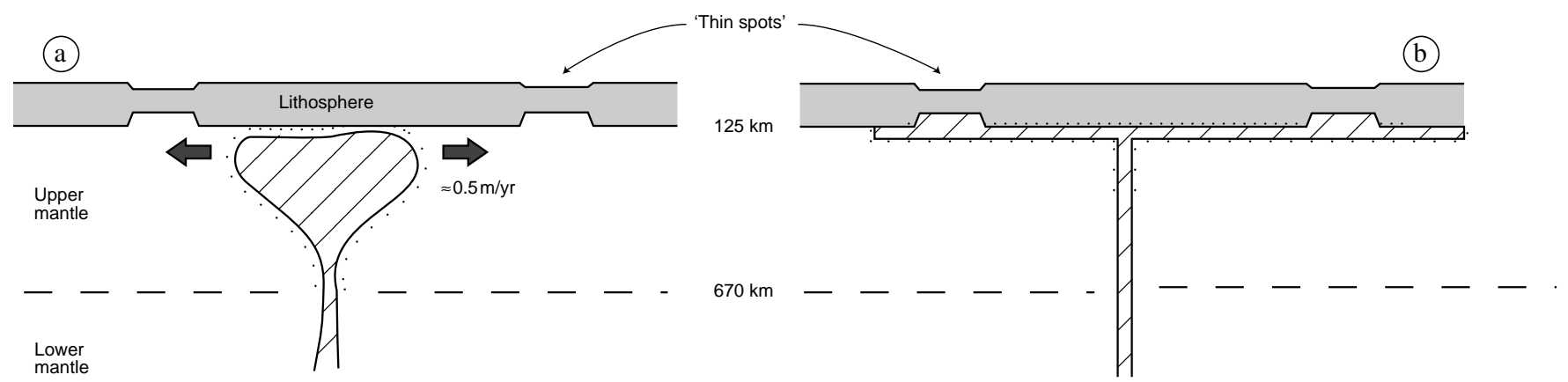

Figure 16. We propose rapid plume impact at approximately 62-61 Ma of a plume head ascending vertically at rates in the order of $\mathrm{m} / \mathrm{yr}$ (a). A non-Newtonian rheology of the upper mantle is assumed (T.B. Larsen and Yuen, 1997). Upon impact below the (Greenland?) lithosphere, the plume head spreads out laterally at rates of about $0.5 \mathrm{~m} / \mathrm{yr}$, making the arrival time at various offset from the impact center almost indistinguishable by even high-precision dating techniques (b). Frictional heating around the plume head takes place during both vertical ascent and horizontal spreading. A layer of ambient mantle may be trapped between the impacting plume head and the continental lithosphere. Volcanism is restricted to pre-existing thin spots or actively rifting areas. The additional heating (transient) by friction may explain why volcanism initially is vigorous (e.g., Site 917 Lower Series; West Greenland picrites; Storey et al., 1996), but ceases (Site 917 Middle Series) unless reactivated by further decompression (Site 917 Upper Series and main SDRS series). See also main text and Figure 17.

stem behind the plume head (Fig. 16). However, during ascent and spreading of the plume head, significant transient heating of the ambient mantle takes place due to friction against the colder, less viscous mantle (T.B. Larsen et al., 1996). However, in this model the effect of a mechanical (rigid) lithosphere is not accounted for. We suggest that frictional heating is particularly strong at the base of the lithosphere, and consequently, ambient (asthenospheric) mantle trapped in this location during plume impact is a likely contributing source to the early volcanism (Figs. 16, 17).

Initially, the lithospheric lid will limit the upper boundary of the melting zone to relatively large depths (e.g., Fram and Lesher, 1993, 1997), and unless the temperature anomaly is very strong, melting may not extend significantly into the plume head layer itself outside areas of active extension allowing for relatively deeper (in a stratigraphic sense) melting (Fig. 17).

The Leg 152 drilling transect is unique within the North Atlantic by providing in one place a stratigraphic record of the entire development from early continental volcanism through steady-state igneous crustal accretion. The main characteristics of this development are initial predominance of a depleted mantle source (Continental Succession) melting below the continental lithosphere (i.e., within the garnet stability field), followed by collapse and removal of the continental lithosphere and melting at a shallower level (largely within the spinel field; see also below) from a less depleted, Icelandic-type mantle (depleted end-member of the Iceland array; see Fitton et al., Chap. 28 , this volume). A significant break in volcanism (or very low productivity phase) took place between formation of the Continental Succession and the steady-state igneous crustal formation (SDRS crust). Noteworthy also are the six high $\mathrm{Nb} / \mathrm{Zr}$ lavas within the Continental Succession. These flows make up $\sim 15 \%$ of the flows in the Lower Series, and compare in composition with nondepleted Icelandic tholeiites and hence, are less depleted than any other lavas recovered during Leg 152.

We conclude that all of these observations are consistent with the model proposed (Figs. 16, 17). In particular we stress that this model is able to explain the parallel presence, but selective tapping, of both depleted asthenospheric mantle and a less depleted (Iceland) plume type mantle. The model would suggest that the high $\mathrm{Nb} / \mathrm{Zr}$ lavas within the Continental Succession, despite their relative enrichment compared to the main SDRS series, had the same source. We suggest that the parental magma of these high $\mathrm{Nb} / \mathrm{Zr}$ lavas formed at larger depth and at lower degree of melting (Fig. 17) than the lavas within the main SDRS series and therefore shows relative enrichment in incompatible elements. Finally, breakup did not take place off south-

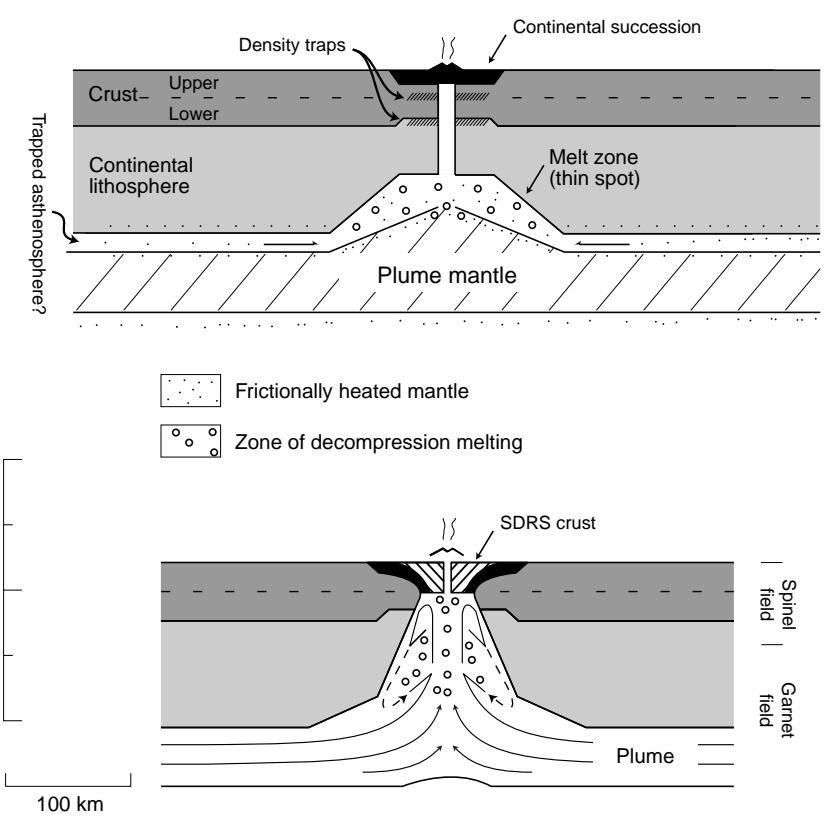

Figure 17. The southeast Greenland "thin spot" during initial impact and generation of the Continental Succession (upper panel). The Continental Succession seems, except for six high $\mathrm{Nb} / \mathrm{Zr}$ flows near the top of the Lower Series, derived from a depleted source, possibly asthenospheric mantle. We suggest that this is a trapped layer of ambient asthenospheric mantle strongly heated during plume impact (frictional and conductive heating). Small dots mark frictional heating, and small open circles melting zones. The melt zone is indicated to just reach into the top part of a layer of plume mantle, which may yield minor amounts of melt (high $\mathrm{Nb} / \mathrm{Zr}$ lavas). Non-mixing of the various mantle sources may be supported by a non-Newtonian mantle rheology (Ten et al., 1997). Following thinning of the continental lithosphere and crust, the sublithospheric mantle is able to rise quickly, decompress, and produce significant amounts of melts at a shallower level (lower panel). Initially, this may be confined to remnants of the initial, depleted source, but with time, plume mantle is bound to flow in below the rift zone (shown by arrows) and contribute to the melts. This stage in breakup corresponds to the Site 917 Upper Series lavas and, possibly, the oldest part of the main SDRS series (Site 990). The depleted nature of the Site 917 Upper Series may also be partly caused by possible, small-scale mantle convection (dashed arrows) leading to multiple melt extraction (Mutter et al., 1988). 
Figure 18. Lateral flow of the plume mantle toward the lithospheric thin spot represented by the developing rift is suggested to take place following a model by Sleep (1997). Flow along the rift axis is also possible, and may have contributed to excessively large distribution of SDRS wedges along the North Atlantic volcanic rifted margins. Thus, the original diameter of the plume sheet, which developed from the impacting plume head, may have been less $(2000 \mathrm{~km}$ ?) than the entire total length of the SDRS margins $(2700 \mathrm{~km})$. This model implies that it is the rheology of the plume layer and the (inverse) topography of the lithosphere that controls the thickness of the melting column below the rift zone, and not the original thickness of the plume sheet. The model provides an explanation for the excessively high rates of magmatic flux along the SDRS rift that we observe.
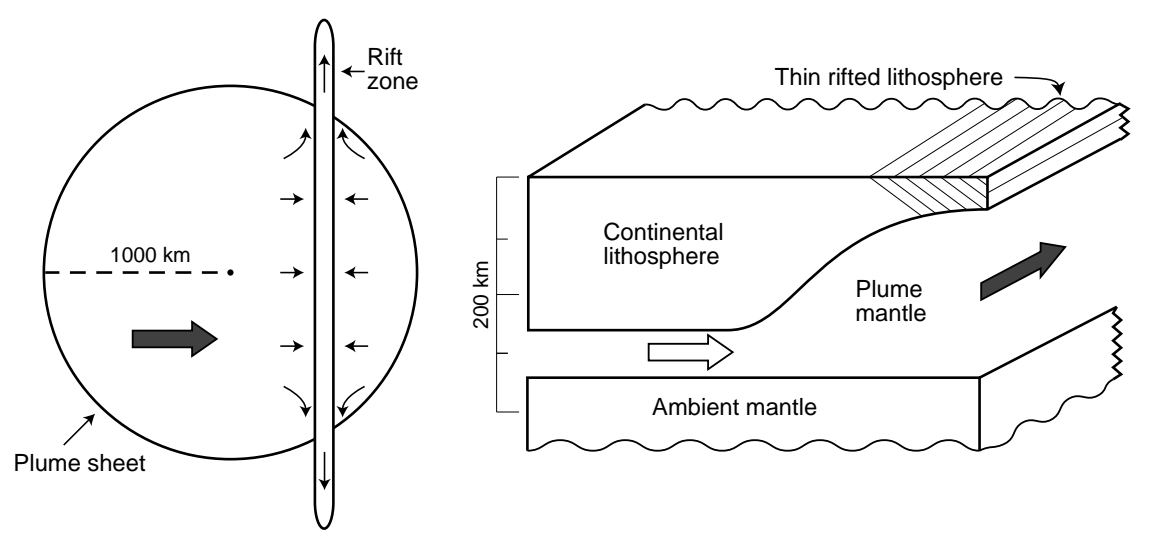

east Greenland immediately after plume impact (as it did in the northern Labrador sea; Chalmers et al., 1993). We therefore interpret the break in volcanism after the initial impact and associated frictional heating (Continental Succession) to reflect that active decompression was needed to more extensively melt the plume head, and hence, that the temperature anomaly within the plume head is not excessively large (approximately $100^{\circ} \mathrm{C}$ according to Thy et al., this volume).

\section{Volume of Plume Material}

Initial (i.e., at 61-62 Ma) NAIP magmatism comprises an area with a diameter of minimum $2000 \mathrm{~km}$ (Fig. 2). The total length of the northeast Atlantic rift zone along which we see formation of the anomalous SDRS crust is even longer than that. However, SDRS formation reflects active rifting and plate separation, which in the northeast Atlantic took place approximately 3-5 m.y. later than plume impact. Thus, channelized flow of hot, low-viscosity mantle away from the initial 2000-km plume sheet and along the rift zone (e.g., Sleep, 1997) may explain this wider distribution (Fig. 18). We therefore base our volume estimate of the impacting plume head on a circular shaped sheet (disk) with a diameter of $2000 \mathrm{~km}$ (Figs. 16, 18). No firm constraints on the thickness of this plume sheet exist. However, we note that, if its average thickness is $50 \mathrm{~km}$, the total volume is approximately $150 \times 10^{6} \mathrm{~km}^{3}$. This is equal to the volume of a sphere with a diameter of approximately $670 \mathrm{~km}$, that is, similar to the thickness of the upper mantle. We consider this the upper limit for a model based on non-Newtonian mantle rheology (Fig. 16; T.B. Larsen et al., 1996; T.B. Larsen, pers. comm., 1997).

An average thickness of the plume sheet of no more than $50 \mathrm{~km}$ would be consistent with the observation that during final breakup (i.e., removal of the lithospheric lid-effect; Fram and Lesher, 1993, 1997), the primary zone of melting moves from the garnet-lherzolite field into the spinel-lherzolite stability field (Fram et al., this volume; Fitton et al., Chaps. 28 and 29, this volume). However, the lower boundary of the melting zone could well continue to extend below the spinel-lherzolite stability field (Fig. 17); as long melts generated within the spinel-field are dominating, the deeper melting event will not deflect the REE pattern of the erupted lavas significantly.

We can also estimate the minimum volume of plume head material from the calculated (maximum) total magmatic flux through the spreading ridge along which the main SDRS wedge formed $\left(3.6 \times 10^{6}\right.$ $\mathrm{km}^{3} / \mathrm{m}$.y.; see earlier in this paper). Thy et al. (this volume) estimate an average of $15 \%$ degree of melting during SDRS formation. Applying this estimate to the estimated magmatic flux results in a depletion rate of the anomalous plume head mantle of around $24 \times 10^{6} \mathrm{~km}^{3} / \mathrm{m}$.y. The main phase of SDRS crust formation took about 3 m.y., and hence, about $72 \times 10^{6} \mathrm{~km}^{3}$ (i.e., roughly half of the above estimated maximum plume head volume) of the plume head were processed and exhausted by generation of new igneous crust during this phase. Part of this may have been compensated through continued plume inflation, but on the other hand, we have not included melt extraction along the West Greenland Margin or other rift systems peripheral/prior to the northeast Atlantic SDRS-rift zone. We therefore consider this estimate a realistic minimum estimate of the volume of the original plume head. It thus seems that the average thickness of a plume sheet with a diameter of $2000 \mathrm{~km}$ must have been between approximately 25 and $50 \mathrm{~km}$ (or with a volume between approximately $75 \times$ $10^{6} \mathrm{~km}^{3}$ and $150 \times 10^{6} \mathrm{~km}^{3}$. Thus, even the minimum estimate of the plume head volume is equal to the volume of a sphere with a diameter of approximately 0.8 times the thickness of the upper mantle. This minimum estimate is close to the estimate by Coffin and Eldholm (1994). They also based their estimate on observed magmatic additions to the North Atlantic crust and, therefore, inherently assumed that virtually all of the anomalous mantle emplaced during plume impact actually suffered melt extraction.

\section{Magmatic Flux Represented by the SDRS Crust}

The high magmatic flux represented by the SDRS crust is difficult to explain. This is because no data suggest that either the thickness of the melting zone or the degree of melting are particularly anomalous compared to normal mid-ocean ridges. Furthermore, volume considerations and geochronological data jointly suggest that the plume reservoir in all likelihood was a widely distributed, but on average, fairly thin $(25-50 \mathrm{~km})$ layer (Fig. 16) from which it seems difficult to generate thick igneous crust at high rates.

Thy et al. (this volume) suggest that the degree of melting typically did not exceed $15 \%$ during formation of SDRS crust. However, if only $15 \%$ of a melting zone $50 \mathrm{~km}$ thick is mobilized as melt, this would result in a melting column (crust) only $7.5 \mathrm{~km}$ thick. This is close to the thickness of normal oceanic crust. We therefore need to consider the possibility of: (1) higher than $15 \%$ degree of melting; (2) a thicker melting zone below the SDRS rift; and (3) forced mantle flow into the rift zone; or a combination of these possibilities.

The presence of a high velocity, lower crust below North Atlantic (and other) SDRS wedges shows that the lower crust has an olivinerich (picritic) composition (see also Kelemen and Holbrook, 1995), which could be indicative of larger than $15 \%$ degree of melting. However, with the present lack of a detailed, crustal velocity structure the relative abundance of such high-velocity/high $\mathrm{MgO}$ crust is not known. This prevents estimation of how much of the lower crust could be explained as simple cumulate rocks balancing the fractionated lavas within the upper crust, and how much could represent truly picritic melt compositions resulting from relatively high degrees of melting (i.e., in excess of the $15 \%$ proposed by Thy et al., this volume). 
Nui and Hékinian (1997) report evidence for a range from $10 \%$ melting below slow-spreading ridges (up to $1 \mathrm{~cm} / \mathrm{yr}$ half rate) to $22 \%$ melting below very fast-spreading ridges $(6-8 \mathrm{~cm} / \mathrm{yr})$. According to their data, the spreading rate of $4.4 \mathrm{~cm} / \mathrm{yr}$ across the southeast Greenland SDRS crust would result in melting of $18 \%-20 \%$ if normal temperature mantle was involved. On this background, the $15 \%$ (to maximum 18\%) estimate by Thy et al. (this volume) seems on the low side even at normal mantle temperatures. However, we have found no indication of the excessively high degree of melting (approximately $40 \%$ ) that would be required to explain formation of the SDRS crust from a relatively thin plume layer and passive upwelling within this.

The modeling of plume behavior below a lithosphere with variable thickness (Sleep, 1997) offers a possibility for a thicker plume layer to develop below pre-existing thin spots and, in particular, below the initial spreading ridge (Figs. 17, 18). Sleep (1997) approximates the non-Newtonian rheology of the upper mantle (e.g., T.B. Larsen et al., 1996; T.B. Larsen and Yuen, 1997) by assigning low viscosity $\left(0.4 \times 10^{18} \mathrm{~Pa} \mathrm{~s}\right)$ to a plume layer impacting below a lithosphere with variable thickness, and show that plume mantle can flow toward "thin spots" at rates significantly higher than typical rates of plate separation and effectively level the inverse relief on the bottom of the lithosphere. Thus, in this scenario the maximum thickness of the plume layer below the SDRS spreading ridge largely is controlled by the maximum (inverse) relief at the base of the lithosphere (Figs. $17,18)$ and not by the original, average thickness of the plume layer.

Thus, ponding plume material below the developing rift, a component of active upwelling (see Langmuir et al., 1992, for definition of active upwelling at oceanic rifts), and 15\%-20\% (decompression) melting of a $100-\mathrm{km}$-thick plume layer are all able to explain the excessive melt generation and large crustal thickness during initial SDRS formation. During this stage, enhanced convection (Mutter et al., 1988) could well take place; the increasing depletion with time of the picritic Site 917 Upper Series might be consistent with this. However, Leg 152 findings show that the SDRS crust continued to form in the same manner for 3 m.y. over a zone more than $100 \mathrm{~km}$ wide (half width; symmetric development on the conjugate margin is assumed), and with an apparently constant, (depleted) Iceland plume source. This implies that much larger volumes of plume mantle than that initially present directly below the rift zone during early breakup must have contributed to the formation of the entire SDRS crust. This requires a continuous lateral flow of the plume layer toward the accretionary plate boundary at rates between 11 and $22 \mathrm{~cm} / \mathrm{yr}$ using the parameters shown in Figure 19. This flow pattern is distinctly different from that below normal mid-ocean ridges, but eventually, the plume layer is exhausted and thinned below the minimum thickness allowing the process to work.

In the later stages of SDRS formation, the underlying asthenospheric mantle is likely to shallow below the spreading axis (Fig. 19). This could cause incipient melting within the shallowest part of the growing asthenospheric high, if this (colder) mantle is entering its melting window (Fig. 19). As growth of the asthenosphere high, at least initially, is likely to be slow, rise of this mantle may not be truly adiabatic, and hence, melting insignificant. However, once melting is accelerating, it may help the asthenosphere to break through the plume layer and bring an end to the SDRS formation, which cannot be maintained by melting of ambient asthenosphere. Another "choke factor" is the accumulated residual mantle below the SDRS crust (shown by dashed, sigmoidal lines in Fig. 19). This is still not part of the mechanical lithosphere and may, when it starts cooling, slide down and block flow of plume mantle into the rift zone.

From our model (Fig. 19) one would predict a slightly decreasing effectiveness of the system (i.e., gradual thinning of SDRS crust with time), and a fairly rapid transition into oceanic crust of close to normal thickness. Associated with this, one would expect significant subsidence of the rift zone and adjacent SDRS crust due to the remov- al of the hot plume layer below the rift zone and below the adjacent SDRS crust. However, in the northeast Atlantic, the arrival of the plume stem below the spreading axis in the Denmark Strait at, or shortly after, this time is, as discussed below, likely to have led to significant axial plume flow southward along the paleo-Reykjanes Ridge, and the final stages of SDRS formation thus may have been more complex than the model (Fig. 19) predicts.

\section{Rate of Inflation and Depletion of Plume Head}

Wolfe et al. (1997) found no evidence from seismic tomography for a plume head below present-day Iceland, but rather an upward narrowing of the plume stem toward the Iceland rift zone. This observation supports the interpretation by Larsen and Jakobsdóttir (1988) that the initial plume head was rapidly exhausted, and that the entire Faeroe-Iceland-Greenland Ridge is the result of plume stem discharge directly into the mid-ocean ridge (Iceland rift zone). Thus, the observed decay of the plume signature southward along the presentday Reykjanes Ridge (e.g., Schilling et al., 1983; Saunders et al., in press) could reflect channelized flow of plume material away from the feeding point of the plume stem, rather than a zoned plume head as such. Based on the observation of $\mathrm{V}$-shaped basement ridges extending from Iceland and converging toward the spreading ridges north and south of Iceland, P. Vogt since 1971 has advocated that such axial flow takes place at rates of 10 to $20 \mathrm{~cm} / \mathrm{yr}$ (Vogt, 1971, 1983; see summary in Wolfe et al., 1997, and White, 1997). These rates are very similar to the rates of mantle flow suggested by us (11$22 \mathrm{~cm} / \mathrm{yr}$ ) to operate during breakup (Figs. 17, 19)

We assume that the maximum flux of mantle through the Iceland plume stem is less than required to create a melt volume equal to the rate of total crustal accretion (approximately $0.6 \mathrm{~km}^{3} / \mathrm{yr}$ ) along the mid-ocean ridge along which a compositional or thermal imprint of the Iceland plume can be seen (approximately $1000 \mathrm{~km}$; see Klein and Langmuir, 1987; Fitton et al., Chaps. 28 and 29, this volume). We base this assumption on the following: (1) if the flux was larger than that, a mantle plume head would still be present below Iceland, and with current resolution of seismic data (Wolfe et al., 1997), we do not see evidence for this to take place; (2) the chemical imprint of the Iceland plume significantly decreases southward along the Reykjanes Ridge; and (3) an axial ridge valley becomes present at approximately $500 \mathrm{~km}$ offset from Iceland. Thus, at $20 \%$ degree of melting within the plume stem, the maximum mantle flux would be approximately 3 $\mathrm{km}^{3} / \mathrm{yr}$. However, because significant contributions to crustal formation from the ambient asthenospheric mantle are likely to take place at offsets larger than (minimum) $500 \mathrm{~km}$, the actual flux is likely to be significantly lower; it is unlikely to exceed $2 \mathrm{~km}^{3} / \mathrm{yr}$.

The seismic tomography study by Wolfe et al. (1997) shows a 200- to $300-\mathrm{km}$-diameter plume stem below Iceland extending to at least $400 \mathrm{~km}$ depth and narrowing upward. If the diameter of the zone of rapid mantle flow within the stem is only, say, $150 \mathrm{~km}$, a flux of 2 $\mathrm{km}^{3} / \mathrm{yr}$ translates to a vertical ascent rate of approximately $12 \mathrm{~cm} / \mathrm{yr}$, that is, of the same order as the horizontal flow rate along the spreading ridge (Vogt, 1983); this is also comparable to the horizontal flow rates calculated for mantle flow within the plume head sheet following the initial very high rates of plume emplacement. With a flow rate through the plume stem of $2 \mathrm{~km}^{3} / \mathrm{yr}$, a plume head with volumes between 75 and 150 million $\mathrm{km}^{3}$ would take between 35 and 70 m.y. to inflate. Additional time should be added to compensate for cooling of the plume head. We therefore conclude that a plume incubating at rates in the order of $2 \mathrm{~km}^{3} / \mathrm{yr}$ is not realistic. However, our estimated mantle ascent rate within the Iceland plume stem is over one order of magnitude below the initial impact ascent rates suggested by T.B. Larsen et al. (1996). Thus, if similar rates operated within an initial plume stem of the size of the Iceland plume stem, incubation rates in the order of a few million years could be achieved. But a large diam- 

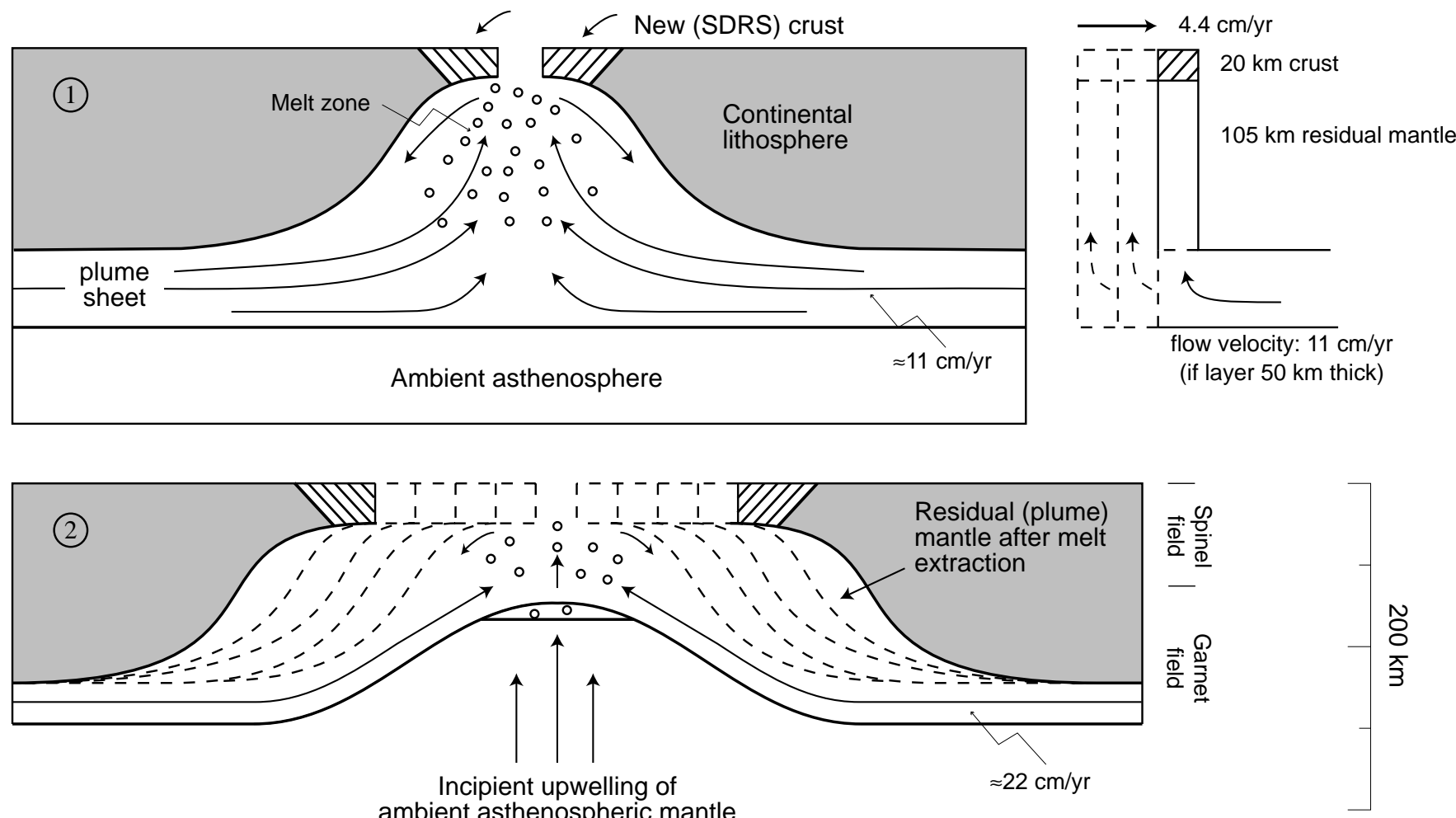
ambient asthenospheric mantle

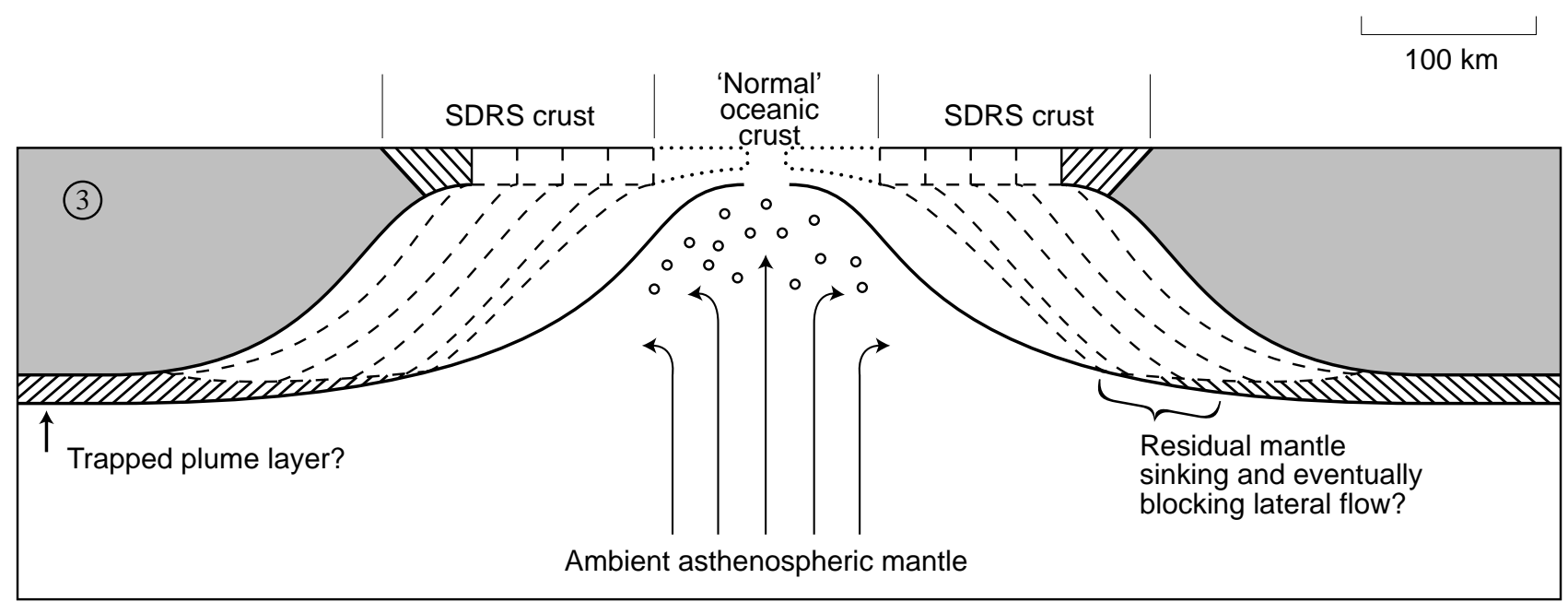

Figure 19. Suggested pattern of active mantle flow (active flow, see Langmuir et al., 1992) during generation of SDRS crust. Panel 1 shows the initiation of spreading (formation of initial SDRS crust), followed by steady-state generation of SDRS crust (panel 2), and finally transition to generation of more normal oceanic crust (panel 3). This interpretation builds on the model in Figure 18. To generate the magmatic fluxes that we observe within the SDRS crust, lateral flow of mantle in the order of $11-22 \mathrm{~cm} / \mathrm{yr}$ into the rift zone is needed. With lithospheric thickness of originally $125 \mathrm{~km}$ and parameters as shown, the degree of melting is around $15 \%-20 \%$. Residual mantle after melting is indicated by dashed lines. If excess temperature of the plume is only $100^{\circ} \mathrm{C}$ as indicated by Thy et al. (this volume), melting initially is not likely to extend into the underlying, ambient (cooler) asthenosphere. However, with time this may slowly rise (and melt) below the rift zone. Finally, ambient asthenosphere breaks through, and a normal pattern of passive mantle upwelling and corner flow is initiated.

eter plume stem ascending at this high rate in fact is very close to the model of a rapidly ascending pear-shaped plume head followed by a narrow tail (Fig. 16); in this case the difference between rapidly impacting and spreading plume heads and incubating plumes is more of a semantic question than a question of significantly different physical behavior.
If the plume stem initially was located below Greenland west of the accretionary plate boundary (SDRS rift) as suggested by Lawver and Müller (1994), accretion of new oceanic crust and lithosphere preferably would exhaust the eastern (northeast Atlantic rift) and western (Labrador Sea-Baffin Bay rift) parts of the plume head. Thus, continued nourishment of the central part of the plume sheet below 
the Greenland lithosphere is likely to have taken place until the central plume stem eventually arrived below the spreading ridge (northern paleo-Reykjanes Ridge within the Denmark Strait), and could have caused extended magmatism along the East Greenland Margin (Storey et al., 1996; Bernstein et al., 1996; Tegner et al., 1996).

\section{SUMMARY AND DISCUSSION}

We first summarize and discuss the primary conclusions that can be drawn from the recovered volcanic stratigraphy, then the structure of the COT, and finally the model of plume emplacement we have developed.

\section{Origin and Composition of the SDRS Wedge}

The southeast Greenland SDRS wedge (Figs. 3, 4) formed from a subaerially exposed spreading ridge much like the present-day Iceland rift zone. Spreading rates were exceptionally high $(4.4 \mathrm{~cm} / \mathrm{yr}$, half-rate) from shortly after the start of spreading until about magnetic Chron C24n time ( $53 \mathrm{Ma})$, which is the oldest well-developed seafloor-spreading anomaly in the northeast Atlantic Ocean. The calculated high spreading rate (Fig. 9) may be slightly overestimated in terms of rates of actual plate separation because of the anomalous structure of the SDRS crust where lavas form a much thicker layer, and flow farther away from the rift zone, than in normal oceanic crust. This could cause some "smearing" effect or offset of the recorded magnetochrons (cryptochrons) and crustal ages compared to true crustal accretion.

Spreading started at, or just after, magnetic Chron 25n ( 56 Ma). During the interval 56 to $53 \mathrm{Ma}$, thick igneous, Icelandic-type crust formed (Fig. 11) and represents an anomalous high magmatic flux, possibly as high as $1.3 \mathrm{~km}^{3} / \mathrm{k} . \mathrm{y} . / \mathrm{km}$ rift length. The thickness of the SDRS wedge (i.e., extrusive layer) is typically about $6 \mathrm{~km}$, and total crustal thickness up to $20 \mathrm{~km}$. Because of the dipping, shingled stratigraphic structure of the SDRS, its integrated stratigraphic thickness is much larger. It is likely to comprise in the order of 4500 major lava flows with a typical thickness of about $7 \mathrm{~m}$, and the average eruption frequency within the SDRS rift must have been about one eruption every $670 \mathrm{yr}$ or higher. This is close to that observed in the eastern Iceland rift zone. In line with the high eruption rate, no interbedded sediments where found in the main SDRS series. Compositionally, the main SDRS lavas seem to be of uniform nature and geochemically indistinguishable from depleted Icelandic tholeiites.

Landward of, and stratigraphically below, the main SDRS wedge, drilling at Site 917 recovered two series of subaerially erupted lavas, which we have grouped into the Continental Succession (Figs. 4, 5). This succession is significantly older than the main SDRS series, most likely between 60 and $61 \mathrm{Ma}$ (i.e., older part of C26r), but an even slightly older age cannot be entirely excluded (61-62 Ma; youngest part of 27r). The Continental Succession erupted through continental lithosphere and crust, and was involved in later block faulting associated with the final crustal and lithospheric thinning prior to breakup. Only scarce and thin soil- or sediment horizons were recovered within the Continental Succession, suggesting fairly constant and high eruption frequency, tentatively estimated at (minimum) one eruption every 11 k.y. The Continental Succession is highly variable in composition, ranging from picrite over olivine basalt and basalt to dacite and acid tuff. It represents fairly deep melting of a hot, for the most part, depleted mantle source. Initially, pulses of new primitive magma were fractionated and became contaminated in crustal magma chambers (Site 917 Lower Series). This phase was followed by dwindling supply (and eventual cessation) of new primitive magma (Site 917 Middle Series).

Following a break in volcanism of unknown duration (maximum 4 m.y.), represented in the drill core by an unconformity and a thin sediment horizon, the picritic Site 917 Upper Series was erupted. De- spite the poorly known age of this series (i.e., between 56 and $60 \mathrm{Ma}$ ), we have chosen to group these lavas with the main SDRS series into the Oceanic Succession. This is because these lavas show evidence of marked shallowing of the melt zone and a strong decrease in the amount of continental contamination. Thus, the Site 917 Upper Series represents the main phase of attenuation and breakup of the continental lithosphere and crust. Accordingly, in terms of the geodynamic regime, these lavas seem connected with the transition into full-scale spreading represented by the main SDRS series overlying the Site 917 Upper Series.

However, the contact between the two series is not known, and the presence of a hiatus between the Site 917 Upper Series and the main SDRS series cannot be excluded. In case of the latter, the Site 917 Upper Series either is transitional between the Continental and Oceanic Successions (in both time and genesis) or is linked in time and genesis to the Continental Succession. Though the latter interpretation seems unlikely, its picritic nature and its depleted mantle source make it somewhat similar to the Site 917 Lower Series of the Continental Succession. However, the intervening Site 917 Middle Series clearly represents a starving system, and thus, the Site 917 Upper Series, as pointed out above, seems to reflect a profound change in the geodynamic regime. Furthermore, a parallel presence within the Site 917 Upper Series of a less depleted source is suggested by Fram et al. (this volume). If correct, this would suggest a more gradual transition into the main SDRS series, but because of contamination problems, the presence of such a second, less depleted, mantle source within the Site 917 Upper Series is questionable (Saunders et al., this volume).

The main SDRS series seems to represent a steady-state production of lavas resembling depleted Icelandic tholeiites. However, the main SDRS series does not show the same variation in enrichment as Icelandic tholeiites (Fitton et al., Chap. 28, this volume). Clearly, our sampling of the main SDRS series is highly incomplete, and furthermore, biased toward major volcanic events that produced flows able to escape the central rift zone and flow tens of kilometers away from this. However, despite these deficiencies, the observed difference may be real and reflect that melting below Iceland is likely to take place in a much wider vertical range within the rising plume stem. Thus, we note that six lavas within the upper part of the Site 917 Lower Series show REE enrichment similar to Icelandic enriched tholeiites, and we propose that these represent samples of melts from a less depleted mantle source, possibly the plume mantle (Fig. 17).

Despite the continental contamination of the Continental Succession, it is suggested by Fitton et al. (Chap. 28, this volume) that the parental magmas have been derived from a depleted source similar to a N-MORB source. In our model (Figs. 16, 17) we tentatively relate this mantle source to a trapped layer of ambient asthenosphere (and possibly, lithosphere) overlying the plume layer, and frictionally heated during plume impact.

Thus, Icelandic-type compositions are found in both the Continental and the Oceanic Succession. Together with other Leg 152 findings summarized above, this strongly suggest that both in terms of mantle source, excess mantle temperatures, mode of lava emplacement and crustal generation, comparison of the southeast Greenland SDRS with Icelandic-type crust is justified. This implies that a hotter than normal, and less depleted, mantle must have been present during breakup. This mantle was able to support formation of SDRS crust at rates even higher than in Iceland. The SDRS crust is, however, thinner (close to $20 \mathrm{~km}$ ) than below Iceland and the Faeroe-IcelandGreenland Ridge (approximately 30 km; Bott, 1983; Larsen and Jakobsdóttir, 1988; Staples et al., in press).

\section{Structure and Location of Continent-Ocean Transition}

Leg 152 made significant contributions to define the location and structure of the continent-ocean transition (COT). This is about 40 $\mathrm{km}$ wide, and most of the crustal thinning and deformation take place within an only approximately $25-\mathrm{km}$-wide zone (Figs. 11, 12). Thus, 
the inner shelf is floored by close to normal-thickness continental crust, and the Precambrian basement is exposed, or very nearly exposed, at the seabed. Approximately $50 \mathrm{~km}$ offshore crustal thinning starts. This is manifest at the surface by a crustal flexure zone in which early rift lavas and underlying pre-rift sediments are rotated seaward. The flexure zone marks the beginning of a series of seaward-rotated fault blocks that continues another $25 \mathrm{~km}$ seaward where the crust is interpreted to be of entirely igneous origin. The featheredge of the SDRS covers these fault blocks, and only the very oldest part of the SDRS is affected by the faulting. The landward-dipping normal faults separating the fault blocks seem to extend only to mid-crustal level, and the thinning of the lower crust is likely to be of a different nature. We have in another paper (Larsen et al., Chap. 39, this volume) suggested that panels of lower crust actually may be present within the lower part of the new igneous crust, that is, that the lower crust virtually fell apart and remnants of this reside as crustalscale xenoliths within the lower part of the older SDRS crust. Persistent, though low degree of, continental contamination is seen within the oldest part of the SDRS wedge, and is consistent with the hypothesized presence of continental remnants at depth. Contamination of lavas well into the SDRS wedge is also reported from the Hatton Bank SDRS (Morton and Taylor, 1987).

The setting of marine pre-rift sediments below the oldest rift lavas is very similar to exposures of Cretaceous to lower Paleocene pre-rift sediments below early rift lavas farther north along the coast. This strongly suggests that despite rifting taking place within a Precambrian cratonic area, pre-rift basins as thick as $1 \mathrm{~km}$ were present below the present-day outer shelf all along the rifted margin. These basins seem to have acted as lithospheric thin spots and loci for initial volcanism. During this process, magma conduits and crustal magma chambers were established. We envisage, during the final breakup, that these magma conduits and magma chambers served as a pathway for the renewed, vigorous magmatism. In particular, we propose that former mid-crustal magma chambers became inflated and acted as a detachment for upper crustal thinning as demonstrated from the Ivrea-Verbano zone in the Alps (Quick et al., 1994, 1995).

The seaward rotation of fault blocks associated with the final rifting is opposite to what is normally associated with continental rifts and nonvolcanic rifted margins. However, in continental rifts and nonvolcanic margins, the rift is a basin (i.e., topographical depression), and hence, gravity will pull fault blocks toward the low area. This is most easily accommodated by riftward-dipping normal faults and rotation of fault blocks away from the rift (landward rotation). Furthermore, landward rotation of the fault blocks is enhanced by sediment loading, with sediment being transported from the landward site and preferentially deposited in front of the fault scarps on the landward part of the fault blocks. At a volcanic margin rift the opposite occurs. The rift is not a depression (not necessarily a high either), and the rift fill is volcanic and not transported in from the continent, but emanating out from the center of the rift zone, and preferably deposited (and loading) at the seaward end of the fault blocks. We therefore see nothing enigmatic in the observed polarity of the tilted fault blocks, and suggest that this rifting structure is roughly symmetric on the two conjugate margins. The latter is still to be proven, as no good seismic images of the fault block pattern at two conjugate, volcanic rifted margins exist.

The seaward crustal flexuring and rotation of fault blocks seen at the Leg 152 transect are in many ways strikingly similar to the East Greenland dike swarm and coastal flexure zone exposed along the coast farther north (Fig. 3). We have drawn on comparison with these exposures in interpreting the deep crustal structure of the southeast Greenland COT. This is particularly the case regarding the presence of a sheeted dike complex at depth, and its role in dilating the continental crust toward the continent/ocean boundary (Figs. 11, 12). However, in the drill cores, there is no evidence for a sheeted dike complex. The simple explanation for this may be that it is located deeper, and in particular, more seaward than the deep Site 917. Thus, dikes are rare in Iceland within mature, upper crust (i.e., the Tertiary eastern and western Iceland lava plateaus). Likewise, the East Greenland dike swarm shows phenomenal strong lateral gradients in dike intensity from rare, widely scattered dikes to $50 \%$ dikes over distances as short as 5-10 km (Myers, 1980; Myers et al., 1993; Klausen, pers. comm., 1997).

Altogether, our observations suggest that the final stages of crustal attenuation and the focusing of the breakup rift into the narrow, and highly volcanic, SDRS rift developed over a very short time, possibly no more than a few million years. This development and margin structure is consistent with the rifting through rapid emplacement of a narrow, subvertical mantle wedge (Fig. 17) as also suggested by Nicolas et al. (1994).

\section{Model of Plume Emplacement and Mantle Flow}

One very significant finding is that the Continental Succession predates breakup by as much as $4 \mathrm{~m}$.y. The age of the Continental Succession and its location on top uplifted pre-rift sediments place these lavas within the group of initial, 61-62 Ma NAIP magmatism. We interpret this initial magmatism to reflect the rapid emplacement of a sheet of plume material below a region about $2000 \mathrm{~km}$ in diameter (Figs. 16, 18). To satisfy observations on magma fluxes and total volumes of igneous crustal accretion during the early Tertiary NAIP, the average thickness of this sheet is estimated to be close to $50 \mathrm{~km}$ thick, and possibly could not have been less than $25 \mathrm{~km}$. Current geochronological data from the NAIP suggest that this plume sheet spread very rapidly, within the order of 1 m.y. below the whole region, which would imply lateral outward flow within the plume head in the order of $0.5 \mathrm{~m} / \mathrm{yr}$. This seems consistent with recent models of a non-Newtonian upper mantle rheology (T.B. Larsen and Yuen, 1997).

Melt generation within the initial plume sheet took place through lithospheric thin spots like the pre-rift basins along the East Greenland Margin, the British Tertiary Province, or at the developing continental margin off West Greenland. However, while the emplacement of this layer may have aided later breakup, significant magma generation did not occur off southeast Greenland before rifting caused a continuously developing lithospheric thin spot into which the plume layer could flow, decompress, and melt (Figs. 18, 19).

In this regard, the precise age of the Site 917 Upper Series is critical. If the age of these lavas is close to the initial 60-62 magmatic phase, this would suggest that the plume had a major impact on lithospheric structure (i.e., thinning). However, if their age is closer to the main SDRS wedge (i.e., $~ 56-57 \mathrm{Ma}$ ) one would see the plume impact as playing a slightly more passive or indirect role, and the control exerted by the pre-existing (inverse) relief of the lithosphere as relatively more important. In any case, plume-related volcanism took place 4-5 m.y. before final breakup, and along the southeast Greenland rift, a hiatus or significantly reduced rate of volcanism, exists between the initial magmatic surface activity of the plume and the beginning of seafloor spreading (Icelandic type).

We propose a model in which the melting column below the developing spreading ridge is controlled by the relief at the bottom of the lithosphere, and where the magmatic flux required to form the SDRS crust at observed rates is provided by lateral flow rate of the plume layer into and below the SDRS rift at velocities of $11 \mathrm{~cm} / \mathrm{yr}$ to $22 \mathrm{~cm} / \mathrm{yr}$ (Fig. 19). These rates are identical to those derived from the interpretation of the $\mathrm{V}$-shaped basement (and gravity) ridges south of Iceland as channelized mantle flow along the Reykjanes Ridge (Vogt, 1983).

The apparent importance of the lithosphere ("lid effect") on mantle melting suggests to us that excess mantle temperature of the plume mantle was modest. If the temperature anomaly was excessively high, the lid effect would be less strong because considerable melting would be able to take place below the continental lithosphere prior to breakup. The reduced amount of mantle melting suggested by the 
Site 917 Middle Series suggests this was not the case. Consistent with this, estimates of excess temperature of the mantle source for both the Continental and Oceanic Successions (compared to a N-MORB source) are around $100^{\circ} \mathrm{C}$ (Thy et al., this volume) and maximum degree of melting between $15 \%$ and $18 \%$. However, we have in this paper suggested that in light of the calculated high spreading rates for the main SDRS series, the latter might be a slight underestimate compared to other, fast-spreading ridges (Nui and Hékinian, 1997).

The thick picritic series of West Greenland (e.g., Gill et al., 1992; Holm et al., 1993) seems to represent much larger fluxes of magma than those represented by the Southeast Greenland Continental Succession and also display higher $\mathrm{MgO}$ content (Storey et al., 1996). Both these features might indicate a stronger thermal anomaly than suggested by the Leg 152 samples. However, the final breakup of the West Greenland Margin coincided with the initial magmatism at C27n-C26r time (Storey et al., 1996), and SDRS crust of C26r age exists (Chalmers et al., 1993). Thus, in terms of geodynamic setting, the West Greenland Margin is different from other parts of the initial NAIP phase, and this may have led to relatively stronger mantle melting in this region.

The verification of anomalously high spreading rates (half rates) during SDRS formation is both interesting and perplexing. Interesting, because the high spreading rate occurred during the time interval where we interpret a (hot) plume sheet to have been located below the lithosphere and to effectively have decoupled the moving plate from the deeper, normal-temperature asthenospheric mantle. Thus, this anomalous mantle sheet may have supported (i.e., lubrication effect; T.B. Larsen et al., 1996) high rates of plate separation, in particular because Greenland during this time formed a separate plate, which for the significant parts would have been underlain by the plume sheet.

However, the high rates are also perplexing because our model seems difficult to reconcile with significant ridge-push as a driving force. Also, slab-pull of the Greenland plate, except for the hypothesized subduction of the northwestern part of the Greenland plate below the Ellesmere Island region (Jackson, 1985) does not seem plausible. One possible explanation could be that the Greenland plate rotated rather than drifted away from Europe during the early phases of plate separation. This would imply that the pole of rotation was fairly close (i.e., Svalbard platform or north of this). Larsen (1988) actually proposed that a rapid northward narrowing of the pre-anomaly $24 n$ igneous crust takes place along the northeast Atlantic rift zone, but tentatively related this to northward rift propagation. Finally, the drilling transect might be located in a margin segment where significant asymmetry in plate accretion was present during breakup, and hence, the high half rates of spreading may be an overestimate of regional northeast Atlantic spreading rates.

\section{The Volume Problem-Is a Plume Model Viable?}

Finally, we briefly address a significant problem associated with the plume model-namely that of the extremely large volumes of anomalous-melt-yield mantle (AMYM) that are required. We have demonstrated that even the minimum required volume of AMYM is equal to a sphere with a diameter similar to the thickness of the upper mantle (from base continental lithosphere to the 670-km discontinuity). The model we propose requires less AMYM than other plume models. This is because the non-Newtonian mantle rheology effectively minimizes the required diameter of the rising plume head (Fig. 16), and because it allows effective depletion of the plume layer by allowing this to flow laterally into the SDRS rift, and thereby minimizes the required plume volume (Figs. 18, 19).

The volume problem has led to the suggestion of a plume incubating over time. However, as we have discussed, to produce the age distribution we see, incubation rates would have to be close to the flux within a rapidly impacting and spreading plume head, and the differ- ence between these models largely become semantic. But not quite. The incubating model implies a mechanism that can force rapid flow of mantle up through a plume stem, and actively inflate a head. In the model we propose, the initial large flux is caused by a large volume of thermally buoyant plume material that accelerates during its passage through the upper mantle while creating a path for a subsequent plume stem with significantly lower mantle flux.

However, even the minimal-sized NAIP plume head is so large (approximately 550-km-diameter sphere) that its opportunity to significantly accelerate during upper mantle ascent is limited (Fig. 16); this to some degree flaws the surging plume model for the NAIP. Continued research into the age distribution and nature of the initial NAIP activity is therefore of high priority to further constrain how fast the plume mantle had to spread upon impact. We note, however, that the rates of lateral flow we have calculated for the post-impact stage, that is, rates in the order of $10-20 \mathrm{~cm} / \mathrm{yr}$, are quite similar to mantle flow velocities calculated for flow along the Reykjanes Ridge (Vogt, 1983). Thus, if we accept these flow rates during post-impact conditions, rates only two to three times larger during plume impact seem reasonable, and we therefore suggest that the surging plume model is a viable model for NAIP formation.

\section{ACKNOWLEDGMENTS}

We thank all our colleagues involved in shipboard work during Legs 152 and 163 and subsequent shore-based studies for their commitment to this project, and for open and beneficial discussions. The synthesis presented here also draws on current research by colleagues at the Danish Lithosphere Centre, and these are thanked by the senior author for use of unpublished data and extensive discussions. C. Lesher and R.A. Duncan are thanked for detailed and constructive review of an earlier version of this paper. L. Stokking, ODP-TAMU, edited an earlier version of this manuscript, and Gigi Delgado, ODPTAMU, coordinated all manuscripts for the volume. They are both thanked. The Danish Natural Research Council funded site surveys prior to Leg 152, and the Danish National Research Foundation funded associated geophysical and geological DLC research.

\section{REFERENCES}

Anderson, D.L., Zhang, Y.-S., and Tanimoto, T., 1992. Plume heads, continental lithosphere, flood basalts and tomography. In Storey, B.C., Alabaster, T., and Pankhurst, R.J. (Eds.), Magmatism and the Causes of Continental Break-up. Geol. Soc. Spec. Publ. London, 68:99-124.

Balkwill, H.R., 1987. Labrador Basin: structural and stratigraphic style. In Beaumont, C., and Tankard, A.J. (Eds.), Sedimentary Basins and BasinForming Mechanisms. Can. Soc. Pet. Geol. Mem., 17-43.

Barton, A.J., and White, R.S., 1995. The Edoras Bank margin: continental break-up in the presence of a mantle plume. J. Geol. Soc. London, 152:971-974.

Berggren, W.A., Kent, D.V., Swisher, C.C., III, and Aubry, M.-P., 1995. A revised Cenozoic geochronology and chronostratigraphy. In Berggren, W.A., Kent, D.V., Aubry, M.-P., and Hardenbol, J. (Eds.), Geochronology, Time Scales and Global Stratigraphic Correlation. Spec. Publ.Soc. Econ. Paleontol. Mineral., 54:129-212.

Bernstein, S., Kelemen, P.B., Tegner, C., Kurz, M,D., and Brooks, C.K., 1996. Post-breakup basaltic magmatism along the East Greenland Continental Margin. Eos, AGU Fall Meeting, 75.

Bird, D.K., Manning, C.E., and Rose, N.M., 1988. Hydrothermal alteration of Tertiary layered gabbros, East Greenland. Am. J. Sci., 288:405-457.

Bird, D.K., Rosing, M.T., Manning, C.E., and Rose, N.M., 1985. Geologic field studies of the Miki Fjord Area, East Greenland. Bull. Geol. Soc. Den., 34:219-236

Björnsson, A., 1985. Dynamics of crustal rifting in NE Iceland. J. Geophys. Res., 90:10151-10162.

Blichert-Toft, J., Rosing, M.T., Lesher, C.E., and Chauvel, C., 1995. Geochemical constraints on the origin of the late Archean Skjoldungen alkaline igneous province, SE Greenland. J. Petrol., 36:515-561. 
Boillot, G., Féraud, G., Recq, M., and Girardeau, J., 1989. "Undercrusting" by serpentinite beneath rifted margins: the example of the west Galicia margin (Spain). Nature, 341:523-525.

Bott, M.H.P., 1983. The crust beneath the Iceland-Faeroe Ridge. In Bott, M.H.P., Saxov, S., Talwani, M., and Thiede, J. (Eds.), Structure and Development of the Greenland-Scotland Ridge. NATO Conf. Ser. IV, New York (Plenum) 63-75.

Brooks, C.K., 1973. Rifting and doming in southern East Greenland. Nature Phys. Sci., 244:23-25.

1979. Geomorphological observations at Kangerdlugssuaq, East Greenland. Greenl. Geosci., 1:1-21.

Brooks, C.K., and Field Parties, 1996. The East Greenland oceanic rifted margin: onshore DLC fieldwork. Bull. Groenl. Geol. Unders., 172:95102

Brooks, C.K., and Nielsen, T.F.D., 1982. The Phanerozoic development of the Kangerlussuaq area, East Greenland. Medd. Groenl. Geosci., 9.

Campbell, I.H., and Griffiths, R.W., 1990. Implications of mantle plume structure for the evolution of flood basalts. Earth Planet. Sci. Lett., 99:79-93.

Cande, S.C., and Kent, D.V., 1992. A new geomagnetic polarity time scale for the Late Cretaceous and Cenozoic. J. Geophys. Res., 97:1391713951.

1995. Revised calibration of the geomagnetic polarity timescale for the Late Cretaceous and Cenozoic. J. Geophys. Res., 100:6093-6095.

Chalmers, J.A., Pulvertaft, T.C.R., Christiansen, F.G., Larsen, H.C., Laursen, K.H., and Ottesen, T.G., 1993. The southern West Greenland continental margin: rifting history, basin development, and petroleum potential. In Parker, J.R. (Ed.), Petroleum Geology of Northwest Europe. Proc. 4th Conf. Geol. Soc. London, 915-931.

Chian, D., Keen, C., Reid, I., and Louden, K.E., 1995. Evolution of nonvolcanic rifted nonvolcanic margins: New results from the conjugate margins of the Labrador Sea. Geology, 23:589-592.

Christiansen, F.G., Larsen, H.C., Marcussen, C., Hansen, K., Krabbe, H., Larsen, L.M., Piasecki, S., Stemmerik, L., and Watt, W.S., 1992. Uplift study of the Jameson Land basin, East Greenland. Nor. Geol. Tidsskr., 72:291-294.

Clarke, D.B., and Pedersen, A.K., 1976. Tertiary volcanic province of West Greenland. In Escher, A., and Watt, W.S. (Eds.), Geology of Greenland. Geol. Surv. Greenl., 364-385.

Clift, P.D., 1996. Temperature anomalies under the Northeast Atlantic rifted volcanic margins. Earth Planet. Sci. Lett., 146:195-211.

Clift, P.D., Turner, J., and ODP Leg 152 Scientific Party, 1995. Dynamic support by the Icelandic plume and vertical tectonics of the northeast Atlantic continental margins. J. Geophys. Res., 100:24473-24486.

Coffin, M.F., and Eldholm, O., 1994. Large igneous provinces: crustal structure, dimensions, and external consequences. Rev. Geophys., 32:1-36.

Dahl-Jensen, T., Holbrook, W.S., Hopper, J.R., Keleman, P.B., Larsen, H.C., Detrick, R., Bernstein, S., and Kent, G., 1997. Bull. Geol. Greenland Surv., 176:50-54

Dam, G., and Sønderholm, M., in press. Sedimentological evolution of a fault-controlled Early Paleocene incised valley system, Nussuaq Basin, West Greenland. In Shanley, K.W., and McCabe, P.J. (Eds.), Relative Role of Eustacy, Climate and Tectonism in Continental Rocks. Spec. Publ.-Soc. Econ. Paleontol. Mineral.

Demant, A., Cambray, H., Vandamme, D., and Leg 152 Shipboard Scientific Party, 1995. Lithostratigraphy of the volcanic sequences at Hole 917A, Leg 152, Southeast Greenland margin. J. Geol. Soc. London, 152:943946.

Den Hartog Jager, D., Giles, M.R., and Griffiths, G.R., 1993. Evolution of Paleogene submarine fans of the North Sea in space and time. In Parker, J.R. (Ed.), Petroleum Geology of Northwest Europe: Proceedings of the 4th Conference. Geol. Soc. London, 59-72.

Duncan, R.A., Larsen, H.C., Allan, J.F., et al., 1996. Proc. ODP, Init. Repts., 163: College Station, TX (Ocean Drilling Program).

Eldholm, O., and Grue, K., 1994. North Atlantic volcanic margins: dimensions and production rates. J. Geophys. Res., 99:2955-2968.

Eldholm, O., Thiede, J., Taylor, E., et al., 1987. Proc. ODP, Init. Repts., 104: College Station, TX (Ocean Drilling Program).

Eldholm, O., Thiede, J., Taylor, E., et al., 1989. Proc. ODP, Sci. Results, 104: College Station, TX (Ocean Drilling Program).

England, R.W., Butler, R.H.W., and Hutton, D.H.W., 1993. The role of Paleocene magmatism in the Tertiary evolution of basin on the NW seaboard. In Parker, J.R. (Ed.) Petroleum Geology of Northwest Europe. Geol. Soc. Spec. Publ. London, 97-105.
Fitton, J.G., Saunders, A.D., Larsen, L.M., Fram, M.S., Demant, A., Sinton, C., and Leg 152 Shipboard Scientific Party, 1995. Magma sources and plumbing systems during break-up of the Southeast Greenland margin: preliminary results from ODP Leg 152. J. Geol. Soc. London, 152:985990.

Fowler, S.R., White, R., Spence, G.D., and Westbrook, G.K., 1989. The Hatton Bank continental margin-II. Deep structure from two-ship expanding spread seismic profiles. Geophys. J., 96:295-310.

Fram, M.S., and Lesher, C.E., 1993. Geochemical constraints on mantle melting during creation of the North Atlantic basin. Nature, 363:712715.

Fram, M.S., and Lesher, C.E., 1997. Generation and polybaric differentiation of East Greenland Early Tertiary flood basalts. J. Petrol., 38:231-275.

Galloway, W.E., Garber, J.L., Xijin, Liu and Sloan, B.J., 1993. Sequence Stratigraphic and depositional framework of the Cenozoic fill, Central and Northern North Sea Basin. In Parker, J.R. (Ed.), Petroleum Geology of Northwest Europe: Proceedings of the 4th Conference. Geol. Soc. London, 2:33-45.

Gill, R.C.O., Pedersen, A.K., and Larsen, J.G., 1992. Tertiary picrites in West Greenland: melting at the periphery of a plume? In Storey, B.C., Alabaster, T., and Pankhurst, R.J. (Eds.), Magmatism and the Causes of Continental Break-up. Geol. Soc. Spec. Publ. London, 68:335-348.

Gleadow, A.J.W., and Brooks, C.K., 1979. Fission track dating, thermal histories and tectonics of igneous intrusions in East Greenland. Contrib. Mineral. Petrol., 71:45-60.

Hansen, H., Rex, D.C., Guise, P.G., and Brooks, C.K., 1989. ${ }^{40} \mathrm{Ar} /{ }^{39} \mathrm{Ar}$ ages on Tertiary East Greenland basalts from the Scoresby Sund area. Eos, $74: 625$

Hansen, K., 1996. Thermotectonic evolution of a rifted continental margin: fission track evidence from the Kangerlussuaq area, SE Greenland. Terra Nova, 8:458-469.

Hémond, C., Arndt, N.T., and Hofmann, A.W., 1993. The heterogeneous Iceland plume: Nd-Sr-O and trace element constraints. J. Geophys. Res., 98:15833-15850.

Henderson, G., Rosenkrantz, A., and Schiener, E.J., 1976. Cretaceous-Tertiary sedimentary rocks of West Greenland. In Escher, A., and Watt, W.S. (Eds.), Geology of Greenland. Geol. Surv. Greenl., 340-362.

Hill, R. I., 1991. Starting plumes and continental break-up. Earth Planet. Sci. Lett., 104:398-416.

Holbrook, W.S., Larsen, H.C., Keleman, P., Dahl-Jensen, T., Korenaga, J., Reid, I., Kent, G., Hopper, J., and Detrick, R., 1997. Spatial and temporal distribution of magmatism during and after continental breakup, Southeast Greenland Margin. Eos, AGU Fall Meeting, 78:668.

Holm, P.M., Gill, R.C.O., Pedersen, A.K., Larsen, J.G., Hald, N., Nielsen, T.F.D., and Thirlwall, M.F., 1993. The Tertiary picrites of West Greenland: contributions from "Icelandic" and other sources. Earth Planet. Sci. Lett., 115:227-244.

Hopper, J.R., Dahl-Jensen, T., Larsen, H.C., and Reid, I., 1996. Crustal structures of the early igneous crust off SE Greenland at 600-1200 km distance from the Iceland hot spot track. Eos, 77:F840.

Jackson, H.R., 1985. Nares Strait-A suture zone: geophysical and geological implications. Tectonophysics, 114:11-28.

Kalsbeek, F. (Ed.), 1989. Geology of the Ammassalik Region, South-East Greenland. Rapp. Groenl. Geol. Unders., 146.

Karson, J., Brooks, C.K., Hanghøj, K., and Nielsen, T.F.F., 1994. Tertiary faulting associated with dike intrusion and flexure on the East Greenland volcanic rifted margin. Eos, 75:608.

Karson, J., Curewitz, D., Brooks, C.K., Story, M., Larsen, H.C., and Pringle, M.S., 1996. Geometry and kinematics of faulting on the Tertiary East Greenland volcanic rifted margin. Eos, AGU Fall Meeting, 75.

Kelemen, P.B., and Holbrook, W.S., 1995. Origin of the thick high-velocity igneous crust along the U.S. east coast margin. J. Geophys. Res. 95:17555-17569.

Kent, R.W., Storey, M., and Saunders, A.D., 1992. Large igneous provinces: sites of plume impact or plume incubation? Geology, 20:891-894.

Klausen, M.B., Brooks, C.K., Nielsen, T.F.D., Svenningsen, O.M., and Karson, J.A., 1996. Infrastructure of the coast-parallel dike swarm along the rifted continental margin of Southeast Greenland. Eos, AGU Fall Meeting, 75.

Klein, E.M., and Langmuir, C.H., 1987. Global correlations of ocean ridge basalt chemistry with axial depth and crustal thickness. J. Geophys. Res., 92:8089-8115.

Knox, R.W., and Morton, A.C., 1988. The record of early Tertiary N Atlantic volcanism in sediments of the North Sea Basin. In Morton, A.C., and 
Parson, L.M. (Eds.), Early Tertiary Volcanism and the Opening of the Northeast Atlantic. Geol. Soc. Spec. Publ. London, 39:407-419.

Langmuir, C.H., Klein, E.M., and Plank, T., 1992. Petrological systematics of mid-ocean ridge basalts: constraints on melt generation beneath ocean ridges. In Morgan, J.P., Blackman, D.K., and Sinton, J.M. (Eds.), Mantle Flow and Melt Generation at Mid-Ocean Ridges. Geophys. Monogr., Am. Geophys. Union, 71:183-280.

Larsen, B., 1980. A marine geophysical survey of the continental shelf of East Greenland $60^{\circ}-71^{\circ}$ N: Project DANA 79. Rep. Geol. Surv. Greenl., 100: 94-98

Larsen, H.C., 1978. Offshore continuation of East Greenland dyke swarm and North Atlantic Ocean formation. Nature, 274:220-223.

, 1980. Geological perspectives of the East Greenland continental margin. Bull. Geol. Soc. Den., 29:77-101.

, 1984. Geology of the East Greenland Shelf. In Spencer, A.M. (Ed.), Petroleum Geology of the North European Margin: London (Graham and Trotman), 329-339.

- 1988. A multiple and propagating rift model for the Northeast Atlantic. In Morton, A.C., and Parson, L.M. (Eds.), Early Tertiary Volcanism and the Opening of the Northeast Atlantic. Geol. Soc. Spec. Publ. London, 39:157-158.

, 1990. The East Greenland Shelf. In Grantz, A., Johnson, G.L., and Sweeney, J.F. (Eds.), The Arctic Ocean Region. Geol. Soc. Am., Geol. of North Am. Ser., L:185-210.

Larsen, H.C., and Duncan, R.A., 1996. Introduction: Leg 163 background and objectives. In Duncan, R.A., Larsen, H.C., Allan, J.F., et al., Proc. ODP, Init. Repts., 163: College Station, TX (Ocean Drilling Program), 513.

Larsen, H.C., Duncan, R.S., Allan, J.F., and ODP Leg 163 shipboard party, 1995. ODP Leg 163, South-East Greenland volcanic rifted margin. Bull. Groenl. Geol. Unders., 172:103-112.

Larsen, H.C., and Jakobsdóttir, S., 1988. Distribution, crustal properties and significance of seaward-dipping sub-basement reflectors off East Greenland. In Morton, A.C., and Parson, L.M. (Eds.), Early Tertiary Volcanism and the Opening of the Northeast Atlantic. Geol. Soc. Spec. Publ. London, 39:95-114.

Larsen, H.C., and Marcussen, C., 1992. Sill-intrusion, flood basalt emplacement and deep crustal structure of the Scoresby Sund region, East Greenland. In Storey, B.C., Alabaster, T., and Pankhurst, R.J. (Eds.), Magmatism and the Causes of Continental Break-up. Geol. Soc. Spec. Publ. London, 68:365-386.

Larsen, H.C., Saunders, A.D., Clift, P.D., Beget, J., Wei, W., Spezzaferri, S., and the ODP Leg 152 Scientific Party, 1994a. Seven million years of glaciation in Greenland. Science, 264:952-955.

Larsen, H.C., Saunders, A.D., Clift, P.D., et al., 1994b. Proc. ODP, Init. Repts., 152: College Station, TX (Ocean Drilling Program).

Larsen, L.M., Watt, W.S., Tegner, C., Storey, M., and Stecher, O., 1996. High-Ti and low-Ti magmas within the central East Greenland Tertiary plateau basalts. Eos, AGU Fall Meeting, 75.

Larsen, L.M., Watt, W.S., and Watt, M., 1989. Geology and petrology of the Lower Tertiary plateau basalts of the Scoresby Sund region, East Greenland. Bull. Geol. Surv. Greenland, 157:1-164.

Larsen, M., 1996. Sedimentology and basin evolution of the CretaceousEarly Tertiary Kangerlussuaq Basin, southern East Greenland. Rep. Geol. Surv. Den. Greenl.

Larsen, M., Hamberg, L., Olaussen, S., and Stemmerik, L., 1996. Cretaceous-Tertiary pre-drift sediments of the Kangerlussuaq area, southern East Greenland. Bull. Geol. Surv. Den. Greenl., 172:37-41.

Larsen, T.B., and Yuen, D.A., 1997. Ultrafast upwelling bursting through the upper mantle. Earth Planet. Sci. Lett., 146:393-399.

Larsen, T.B., Yuen, D.A., Smedsmo, J.L., and Malevsky, A.V., 1996. Thermomechanical modelling of pulsation tectonics and consequences on lithospheric dynamics. Geophys. Res. Lett., 23:217-220.

Lawver, L.A., and Müller, R.D., 1994. Iceland hotspot track. Geology, 22:311-314.

Le Gall, B., and Cambray, H., 1996. Structures of the seaward dipping reflector sequences at Hole 917A from downhole and core measurements (ODP Leg 152, Southeast Greenland Rifted Margin). Eos, AGU Fall Meeting, 75.

Morgan, J.V., Barton, P.J., and White, R.S., 1989. The Hatton Bank continental margin. III: Structure from wide-angle OBS and multichannel seismic refraction profiles. Geophys. J. Int., 98:367-384.

Morton, A.C., Hallsworth, C.R., and Wilkinson, G.C., 1993. Stratigraphic evolution of sand provenance during Paleocene deposition in the Northern North Sea area. In Parker, J.R. (Ed.), Petroleum Geology of North- west Europe: Proceedings of the 4th Conference. Geol. Soc. London, 7384.

Morton, A.C., and Taylor, P.N., 1987. Lead isotope evidence for the structure of the Rockall dipping-reflector passive margin. Nature, 326:381-383.

Mussett, A.E., 1986. ${ }^{40} \mathrm{Ar}-{ }^{39} \mathrm{Ar}$ step-heating ages of the Tertiary igneous rocks of Mull, Scotland. J. Geol. Soc. London, 143:887-896.

Mussett, A.E., Dagley, P., and Skelhorn, R.R., 1988. Time and duration of activity in the British Tertiary igneous province. In Morton, A.C., and Parson, L.M. (Eds.), Early Tertiary Volcanism and the Opening of the Northeast Atlantic. Geol. Soc. Spec. Publ. London, 39:337-348.

Mutter, J.C., Buck, W.R., and Zehnder, C.M., 1988. Convective partial melting, 1. A model for the formation of thick basaltic sequences during the initiation of spreading. J. Geophys. Res., 93:1031-1048.

Mutter, J.C., Talwani, M., and Stoffa, P.L., 1982. Origin of seaward-dipping reflectors in oceanic crust off the Norwegian margin by "subaerial seafloor spreading." Geology, 10:353-357.

Myers, J.S., 1980. Structure of the coastal dyke swarm and associated plutonic intrusions of East Greenland. Earth Planet. Sci. Lett., 46:407-418.

Myers, J.S., Gill, R.C.O., Rex, D.C., and Charnley, N.R., 1993. The Kap Gustav Holm Tertiary Plutonic Centre, East Greenland. J. Geol. Soc. London, 150:259-276.

Neuhoff, P.S., Watt, W.S., Bird, D.K., and Pedersen, A.K., 1997. Timing and structural relations of regional zeolite zones in basalts of the East Greenland continental margin. Geology, 25:803-806.

Nicolas, A., Achauer, U., and Daignaieres, M., 1994. Rift initiation by lithospheric rupture. Earth Planet. Sci. Lett., 123:281-298.

Nielsen, T.F.D., 1978. The Tertiary dike swarms of the Kangerdlugssuaq Area, East Greenland: an example of magmatic development during continental break-up. Contrib. Mineral. Petrol., 67:63-78.

Nielsen, T.F.D., and Brooks, C.K., 1981. The E Greenland rifted continental margin: an examination of the coastal flexure. J. Geol. Soc. London, 138:559-568.

Nielsen, T.F.D., Soper, N.J., Brooks, C.K., Faller, A.M., Higgins, A.C., and Matthews, D.W., 1981. The pre-basaltic sediments and the lower basalts at Kangerdlugssuaq, East Greenland: their stratigraphy, lithology, palaeomagnetism and petrology. Medd. Groenl. Geosci., 6.

Nui, Y., and Hékinian, R., 1997. Spreading-rate dependence of the extent of mantle melting beneath ocean ridges. Nature, 385:326-329.

O'Connor, S.J., and Walker, D., 1993. Paleocene reservoirs of the Everest trend. In Parker, J.R. (Ed.), Petroleum Geology of Northwest Europe: Proceedings of the 4th Conference. Geol. Soc. London, 2:145-161.

Pálmason, G., 1986. Model of crustal formation in Iceland, and application to submarine mid-ocean ridges. In Vogt, P.R., and Tucholke, B.E. (Eds.), The Western North Atlantic Region. Geol. Soc. Am., Geol. of North Am. Ser., M:87-98.

Parsons, B., and Sclater, J.G., 1977. An analysis of the variation of ocean floor bathymetry and heat flow with age. J. Geophys. Res., 82:803-827.

Pearson, D.G., Emeleus, C.H., and Kelley, S.P., 1996. Precise ${ }^{40} \mathrm{Ar} /{ }^{39} \mathrm{Ar}$ ages for the initiation of igneous activity in the Small Isles, Inner Hebrides and implications for the timing of magmatism in the British Tertiary Volcanic Province. J. Geol. Soc. London, 153:815-818.

Pedersen, A.K., Larsen, L.M., Watt, W.S., Neuhoff, P., and Larsen, H.C., 1996. Syn- and post-volcanic structural development of the early Tertiary plateau basalts of the Blosseville Kyst, East Greenland. Eos, AGU Fall Meeting, 75.

Pedersen, A.K., Watt, M., Watt, W.S., and Larsen, L.M., 1997. Structure and stratigraphy of the Tertiary basalts of the Blosseville Kyst, East Greenland. J. Geol. Soc. London, 154:565-570.

Pedersen, G.K., and Pulvertaft, T.C.R., 1992. The nonmarine Cretaceous of the West Greenland Basin, onshore West Greenland. Cretaceous Res., 8:263-272.

Quick, J.E., Sinigoi, S., and Mayer, A., 1994. Emplacement dynamics of a large mafic intrusion in the lower crust, Ivrea-Verbano Zone, northern Italy. J. Geophys. Res., 99:21599-21573.

, 1995. Emplacement of mantle peridotite in the lower continental crust, Ivrea-Verbano zone, northwest Italy. Geology, 23:739-742.

Reid, I.D., Dahl-Jensen, T., Holbrook, W.S., Larsen, H.C., Keleman, P.B., Hopper, J.R., Korenaga, J., Detrick, R., and Kent, G., 1997. 32-38 km thick mafic igneous crust beneath the Greenland-Iceland Ridge. Eos, AGU Fall Meeting, 78:656.

Ribe, N.M., Christensen, U.R., and Theißing, J., 1995. The dynamics of plume-ridge interaction, 1: Ridge-centered plumes. Earth Planet. Sci. Lett., 134:155-168.

Roberts, D.G., and Montadert, L., 1979. Evolution of passive rifted margins-perspective and retrospective of DSDP Leg 48. In Montadert, L., 
Roberts, D.G., et al., Init. Repts. DSDP., 48: Washington (U.S. Govt. Printing Office), 1143-1153.

Roberts, D.G., Schnitker, D., et al., 1984. Init. Repts. DSDP, 81: Washington (U.S. Govt. Printing Office).

Saemundsson, K., 1986. Subaerial volcanism in the western North Atlantic. In Vogt, P.R., and Tucholke, B.E. (Eds.), The Western North Atlantic Region. Geol. Soc. Am., Geol. of North Am. Ser., 69-86.

Saunders, A.D., Fitton, J.G., Kerr, A.C., Norry, M.J., and Kent, R.W., in press. The North Atlantic igneous province. In Coffin, M.F., and Mahoney, J.J. (Eds.), Large Igneous Provinces. Am. Geophys. Union., Geophys. Monogr.

Sawyer, D.S., Whitmarsh, R.B., Klaus, A., et al., 1994. Proc. ODP, Init. Repts., 149: College Station, TX (Ocean Drilling Program).

Schilling, J.-G., 1991. Fluxes and excess temperatures of mantle plumes inferred from their interaction with migrating mid-ocean ridges. Nature, $352: 397-403$

Schilling, J.-G., Zajac, M., Evans, R., Johnston, T., White, W., Devine, J.D., and Kingsley, R., 1983. Petrologic and geochemical variations along the Mid-Atlantic ridge from $29^{\circ} \mathrm{N}$ to $73^{\circ} \mathrm{N}$. Am. J. Sci., 283:510-586.

Schönharting, G., and Abrahamsen, N., 1989. Paleomagnetism of the volcanic sequence in Hole 642E, ODP Leg 104, Vøring Plateau, and correlation with early Tertiary basalts in the North Atlantic. In Eldholm, O., Thiede, J., Taylor, E., et al., Proc. ODP, Sci. Results, 104: College Station, TX (Ocean Drilling Program), 911-920.

Skogseid, J., Pedersen, T., Eldholm, O., and Larsen, B.T., 1992. Tectonism and magmatism during NE Atlantic continental break-up: the Vøring Margin. In Storey, B.C., Alabaster, T.C., and Pankhurst, R.J. (Eds.), Magmatism and the Causes of Continental Break-up. Geol. Soc. Spec. Publ. London, 68:303-318.

Sleep, N.H., 1997. Lateral flow and ponding of starting plume material. $J$. Geophys. Res., 102:10001-10012.

Soper, N.J., Downie, C., Higgins, A.C., and Costa, L.I., 1976a. Biostratigraphic ages of Tertiary basalts on the east Greenland continental margin and their relationship to plate separation in the northeast Atlantic. Earth Planet. Sci. Lett., 32:149-157.

Soper, N.J., Higgins, A.G., Downie, C., Matthews, D.W., and Brown, P.E., 1976b. Late Cretaceous-early Tertiary stratigraphy of the Kangerdlugssuaq area, east Greenland, and the age of opening of the north-east Atlantic. J. Geol. Soc. London, 132:85-104.

Spence, G.D., White, R.S., Westbrook, G.K., and Fowler, S.R., 1989. The Hatton Bank continental margin, I. Shallow structure from two ship expanding spread profiles. Geophys. J., 96:273-294.

Srivastava, S.P., and Tapscott, C.R., 1986. Plate kinematics of the North Atlantic. In Vogt, P.R., and Tucholke, B.E. (Eds.), The Western North Atlantic Region. Geol. Soc. Am., Geol. North Am. Ser., M:379-404.

Staples, R.K., White, R.S., Brandsdottir, B., Menke, W.H., Maguire, P.K.H., McBride, J., and Smallwood, J., in press. Faero-Iceland Ridge Experiment - 1. The crustal structure of north-eastern Iceland. J. Geophys. Res.

Storey, M., Duncan, R.A., Larsen, H.C., Pedersen, A.K., Waagstein, R., Larsen, L.M., Tegner, C., and Lesher, C.A., 1996. Impact and rapid flow of the Iceland plume beneath Greenland at 61 Ma. Eos, 77:F838.

Talwani, M., and Eldholm, O., 1977. Evolution of the Norwegian-Greenland Sea. Geol. Soc. Am. Bull., 88:969-999.

Tarling, D.H., Hailwood, E.A., and Løvlie, R., 1988. A palaeomagnetic study of lower Tertiary lavas in East Greenland and comparison with other lower Tertiary observations in the Northern Atlantic. In Morton, A.C., and Parson, L.M. (Eds.), Early Tertiary Volcanism and the Opening of the Northeast Atlantic. Geol. Soc. Spec. Publ. London, 39:215-224.

Tegner, C., Bernstein, S., Bird, D.K., Duncan, R.A., Storey, M., Brooks, C.K., and Larsen, H.C., 1996. Age and emplacement History of East Greenland Gabbro Intrusions. Eos, AGU Fall Meeting, 75.

Ten, A., Yuen, D.A., Podladschikov, Y.Y., Larsen, T.B., Pachepsky, E., and Malevsky, A.V., 1997. Fractal features in mixing of non-Newtonian and Newtonian mantle convection. Earth Planet. Sci. Lett., 146:401-414.

Thirlwall, M.F., Upton, B.G.J., and Jenkins, C., 1994. Interaction between continental lithosphere and the Iceland plume: $\mathrm{Sr}-\mathrm{Nd}-\mathrm{Pb}$ isotope geochemistry of Tertiary basalts, NE Greenland. J. Petrol., 35:839-879.
Thompson, R.N., and Gibson, S.A., 1991. Subcontinental mantle plumes, hotspots and pre-existing thinspots. J. Geol. Soc. London, 147:973-977.

Turner, J.D., and Scrutton, R.D., 1993. Subsidence patterns in western margin basins: evidence from the Faeroe-Shetland Basin. In Parker, J.R (Ed.), Petroleum Geology of Northwest Europe. Proc. 4th Conf. Petrol. Geol., Geol. Soc. London, 2:975-983.

Vink, G.E., 1984. A hotspot model for Iceland and the Vøring Plateau. $J$. Geophys. Res., 89:9949-9959.

Vogt, P.R., 1971. Asthenosphere motion recorded by the ocean floor south of Iceland. Earth Planet. Sci. Lett., 13:153-160.

, 1983. The Iceland mantle plume: status of the hypothesis after a decade of new work. In Bott, M.H.P., Saxov, S., Talwani, M., and Thiede, J. (Eds.), Structure and Development of Greenland-Scotland Ridge: New Methods and Concepts: New York (Plenum), 191-213.

Waagstein, R., 1988. Structure, composition and age of the Faeroe basalt plateau. In Morton, A.C., and Parson, L.M. (Eds.), Early Tertiary Volcanism and the Opening of the Northeast Atlantic. Geol. Soc. Spec. Publ. London, 39:225-238.

Waagstein, R., and Hald, N., 1984. Structure and petrography of a $660 \mathrm{~m}$ lava sequence from the Vestmanna-1 drill hole, lower and middle basalt series, Faeroe Islands. In Berthelsen, O., Noe-Nygaard, A., and Rasmussen, J. (Eds.), The Deep Drilling Project 1980-81 in the Faeroe Islands. Ann. Soc. Sci. Færoensis, 1984:39-70.

Wager, L.R., 1934. Geological investigations in East Greenland. I: General geology from Angmagssalik to Kap Dalton. Medd. Groenl., 105:1-46.

Wager, L.R., and Deer, W.A., 1938. A dyke swarm and coastal flexure in East Greenland. Geol. Mag., 75:39-46.

White, R.S., 1992. Crustal structure and magmatism of North Atlantic continental margins. J. Geol. Soc. London, 149:841-854.

1997. Rift-plume interaction in the North Atlantic. Philos. Trans. R. Soc. London A, 355:319-339.

White, R.S., Bown, J.W., and Smallwood, J.R., 1995. The temperature of the Iceland plume and origin of outward-propagating $\mathrm{V}$-shaped ridges. $J$. Geol. Soc. London, 152:1039-1045.

White, R.S., McBride, J.H., Maguire, P.K.H., Brandsdottir, B., Menke, W., Minshull, T.A., Richardson, K.R., Smallwood, J.R., Staples, R.K., and FIRE Working Group, 1996. Seismic images of crust beneath Iceland contribute to long-standing debate. Eos, 21:19200-19201.

White, R.S., and McKenzie, D., 1989. Magmatism at rift zones: the generation of volcanic continental margins and flood basalts. J. Geophys. Res. 94:7685-7729.

1995. Mantle plumes and flood basalts. J. Geophys. Res., 100:17543-17585.

Whitmarsh, R.B., White, R.S., Horsefield, S.J., Sibuet, J.-C., Recq, M., and Louvel., V., 1996. The ocean-continent boundary off the western continental margin of Iberia: crustal structure west of Galicia Bank. J. Geophys. Res., 101:28291-28314.

Wolfe, C.J., Bjarnason, I.T., VanDecar, J.C., and Solomon, S.C., 1997. Seismic structure of the Iceland mantle plume. Nature, 385:285-247.

Yuen, D.A., and Larsen, T.B., 1996. Essential ingredients of generating fast mantle plumes: temperature-dependent viscosity versus power-law rheology. Eos, AGU Fall Meeting, 75.

Zehnder, C.M., Mutter, J.C., and Buhl, P., 1990. Deep seismic and geochemical constraints on the nature of rift-induced magmatism during breakup of the North Atlantic. Tectonophysics, 173:545-565.

Ziegler, P.A., 1982. Geological Atlas of Western and Central Europe: Amsterdam (Elsevier).

Date of initial receipt: 10 December 1996

Date of acceptance: 16 April 1997

Ms 152SR-240 